\title{
Potential Health Impacts from Range Fires at Aberdeen Proving Ground, Maryland
}
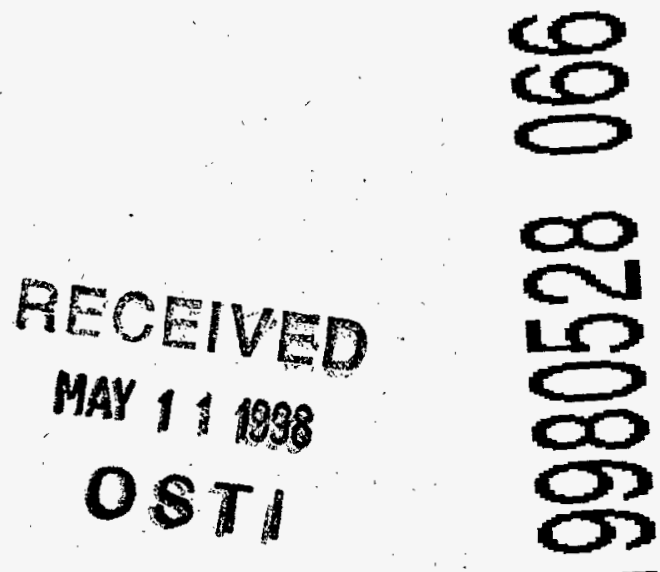

Environmental Assessment Division Argonne National Laboratory

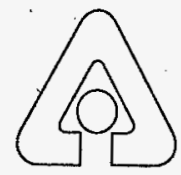

Operated by The University of Chicago,

under Contract W-31-109-Eng-38, for the

DISTRBBUTLON STATEMENT $\mathbf{A}$

Approved for public release;

Distribution Unlimited.
United States Department of Energy [DTC QUATITY INGPJWWD 1 


\section{Argonne National Laboratory}

Argonne National Laboratory, with facilities in the states of Illinois and Idaho, is owned by the United States Government, and operated by the University of Chicago under the provisions of a contract with the Department of Energy.

This technical memo is a product of Argonne's Environmental Assessment Division (EAD). For information on the division's scientific and engineering activities, contact:

Director, Environmental Assessment Division

Argonne National Laboratory

Argonne, Illinois 60439-4815

Telephone (630) 252-3107

Presented in this technical memo are preliminary results of ongoing work or work that is more limited in scope and depth than that described in formal reports issued by the EAD.

Publishing support services were provided by Argonne's Information and Publishing Division (for more information, see IPD's home page: http://www.ipd.anl.gov/).

\section{Disclaimer}

This report was prepared as an account of work sponsored by an agency of the United States Government. Neither the United States Government nor any agency thereof, nor any of their employees, makes any warranty, express or implied, or assumes any legal liability or responsibility for the accuracy, completeness, or usefulness of any information, apparatus, product, or process disclosed, or represents that its use would not infringe privately owned rights. Reference herein to any specific commercial product, process, or service by trade name, trademark, manufacturer, or otherwise, does not necessarily constitute or imply its endorsement, recommendation, or favoring by the United States Government or any agency thereof. The views and opinions of authors expressed herein do not necessarily state or reflect those of the United States Government or any agency thereof.

Reproduced directly from the best avallable copy.

Available to $D O E$ and DOE contractors from the Office of Scientific and Technical Information, P.O. Box 62, Oak Ridge, TN 37831; prices available from

- (423) 576-8401.

Available to the public from the National Technical Information Service, U.S. Department of Commerce, 5285 Port Royal Road, Springfield, VA 22161. 


\section{Potential Health Impacts from Range Fires at Aberdeen Proving Ground, Maryland}

by G.P. Williams, A.M. Hermes, ${ }^{*}$ A.J. Policastro, H.M. Hartmann, and D. Tomasko

Environmental Assessment Division,

Argonne National Laboratory, 9700 South Cass Avenue, Argonne, Illinois 60439

DISTRIBUTION OF THIS DOCUMENT IS UM!MITEO
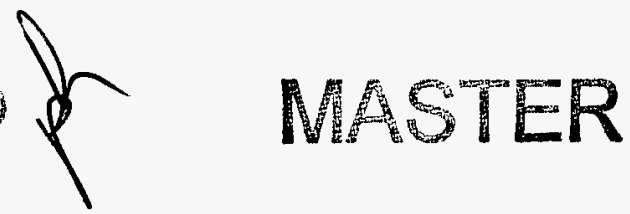

March 1998

Prepared for the U.S. Army, Directorate of Safety, Health, and Environment Aberdeen Proving Ground, Maryland

*Hermes is currently affiliated with Environmental Resource Management, Inc., Houston, Texas. 


\section{CONTENTS}

NOTATION $\ldots \ldots \ldots \ldots \ldots \ldots \ldots \ldots \ldots \ldots \ldots \ldots \ldots \ldots \ldots \ldots \ldots \ldots \ldots \ldots \ldots \ldots$, vii

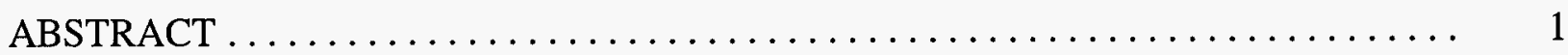

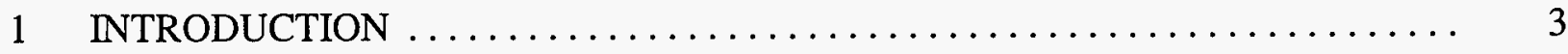

2 ENVIRONMENTAL SETTING $\ldots \ldots \ldots \ldots \ldots \ldots \ldots \ldots \ldots \ldots \ldots \ldots \ldots \ldots \ldots$

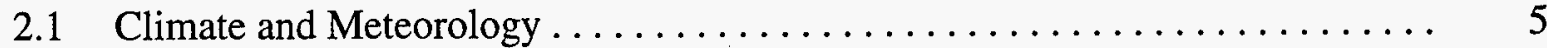

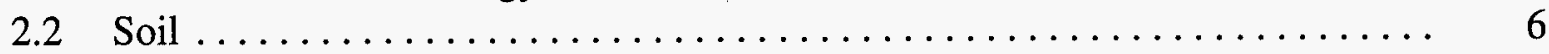

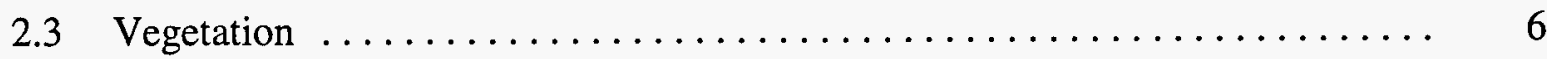

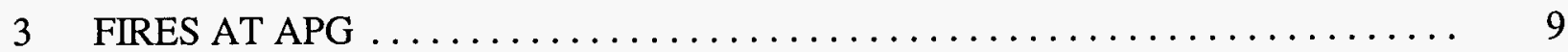

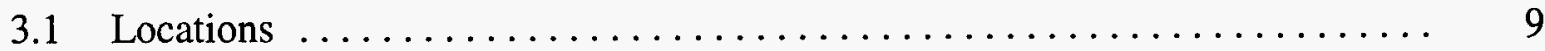

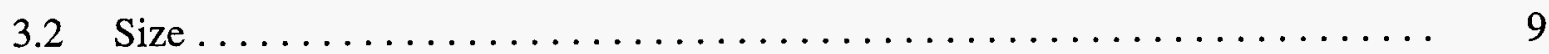

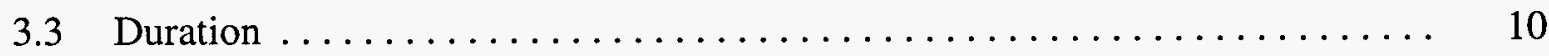

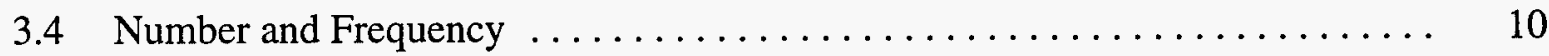

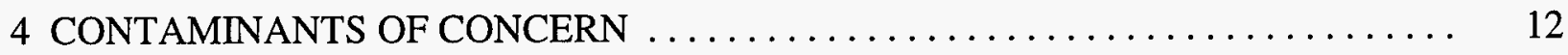

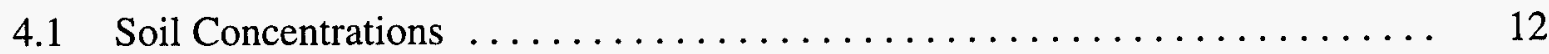

4.2 Chemicals Released from Burning Vegetation $\ldots \ldots \ldots \ldots \ldots \ldots \ldots \ldots . . \ldots \ldots$

4.3 Chemicals Released from UXO Detonation $\ldots \ldots \ldots \ldots \ldots \ldots \ldots \ldots .15$

5 CHEMICAL CHARACTERISTICS $\ldots \ldots \ldots \ldots \ldots \ldots \ldots \ldots \ldots \ldots \ldots \ldots \ldots \ldots$

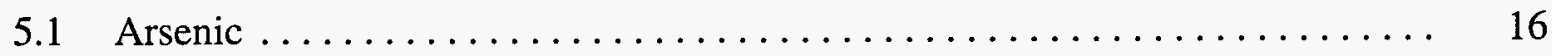

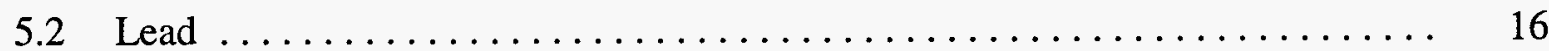

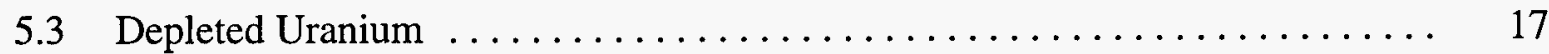

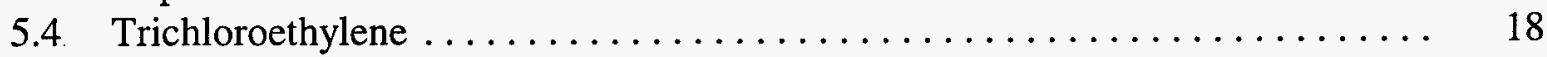

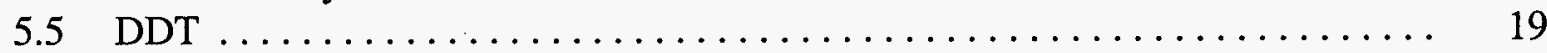

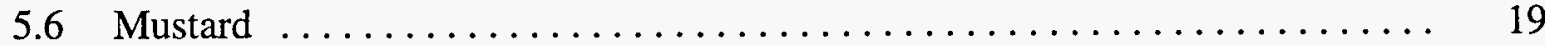

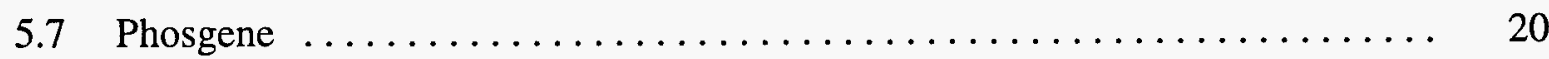

6 BIOMASS INFORMATION/ VEGETATION SURVEYS $\ldots \ldots \ldots \ldots \ldots \ldots, 21$

$7 \quad$ PLANT UPTAKE AND RELEASE MODELS $\ldots \ldots \ldots \ldots \ldots \ldots \ldots \ldots \ldots$

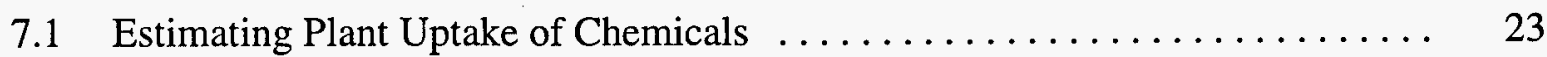

7.1.1 Uptake of Inorganic Contaminants $\ldots \ldots \ldots \ldots \ldots \ldots \ldots \ldots .23$

7.1.2 Uptake of Organic Contaminants ..................... 26

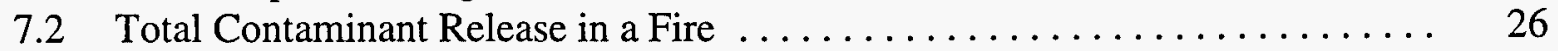




\section{CONTENTS (Cont.)}

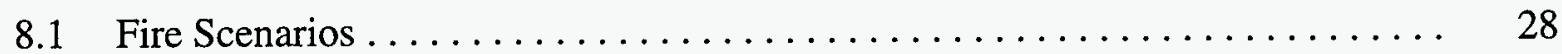

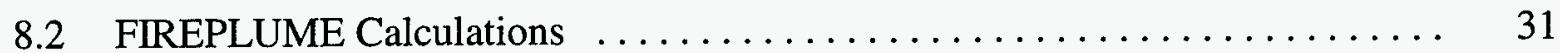

8.3 Soil Deposition from Plume-Borne Contaminants $\ldots \ldots \ldots \ldots \ldots \ldots \ldots$

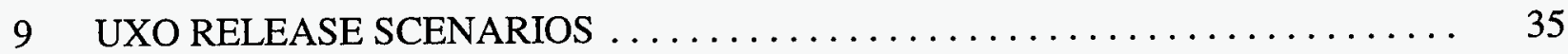

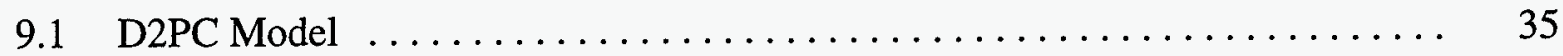

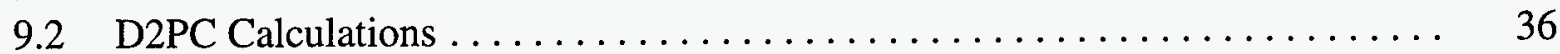

9.3 UXO Release Results . . . . . . . . . . . . . . . . . . . 36

10 RISK ANALYSIS $\ldots \ldots \ldots \ldots \ldots \ldots \ldots \ldots \ldots \ldots \ldots \ldots \ldots \ldots \ldots$

10.1 Screening Action Levels for Chemical Contaminants in Air . . . . . . . . . . 37

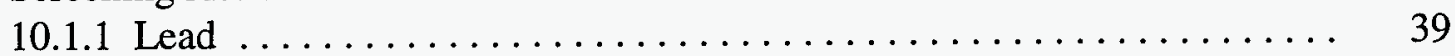

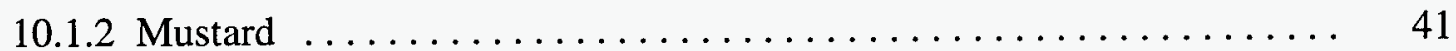

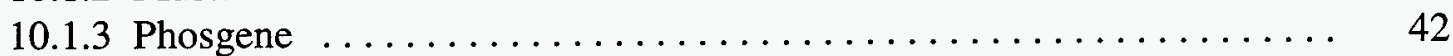

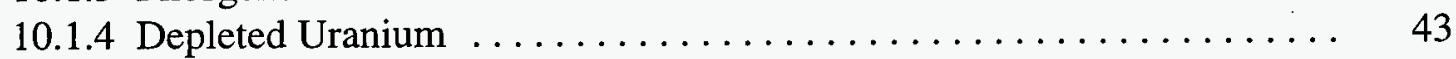

10.2 Comparison of Calculated Plume Values with Screening Levels . . . . . . . . 43

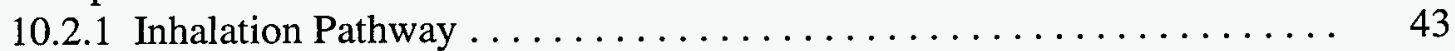

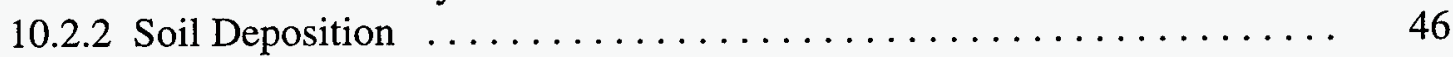

11 DISCUSSION OF RESULTS $\ldots \ldots \ldots \ldots \ldots \ldots \ldots \ldots \ldots \ldots \ldots \ldots$

12 RECOMMENDATIONS $\ldots \ldots \ldots \ldots \ldots \ldots \ldots \ldots \ldots \ldots \ldots \ldots \ldots \ldots \ldots$

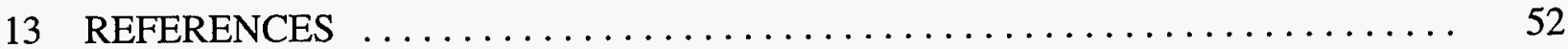

APPENDIX A: FIREPLUME Model Results $\ldots \ldots \ldots \ldots \ldots \ldots \ldots \ldots \ldots \ldots$ A-1

APPENDIX B: Emission Factors for Burning Vegetation $\ldots \ldots \ldots \ldots \ldots \ldots \ldots \ldots \ldots$ B-1

APPENDIX C: Figures $\ldots \ldots \ldots \ldots \ldots \ldots \ldots \ldots \ldots \ldots \ldots \ldots \ldots \ldots \ldots \ldots \ldots \ldots \ldots$

\section{TABLES}

1 Vegetation and Land Cover Areas at APG $\ldots \ldots \ldots \ldots \ldots \ldots \ldots \ldots \ldots$

2 Cover Types and Current Range Areas $\ldots \ldots \ldots \ldots \ldots \ldots \ldots \ldots \ldots \ldots \ldots$ 


\section{TABLES (Cont.)}

3 Contaminant Concentrations in Soil at APG $\ldots \ldots \ldots \ldots \ldots \ldots \ldots \ldots \ldots \ldots \ldots \ldots$

4 Source Values for Chemicals Released from Burning Vegetation $\ldots . \ldots \ldots \ldots \ldots$

5 Total Biomass Available for Consumption in Fire — Forest and Field Areas ..... 22

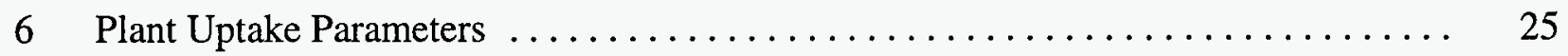

7 Estimated Total Amounts of Contaminants of Concern Released from a

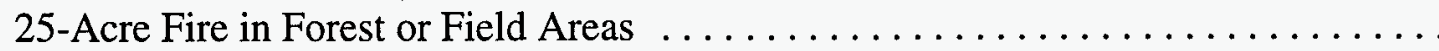

8 Point of Maximum Ground-Level Contaminant Concentration Downwind of a Fire on the Basis of FIREPLUME Modeling Results ...................

9 Maximum Contaminant Concentrations at Ground Level for A, D, and E Atmospheric Stability Classes in Forest and Field Fires as Predicted by the

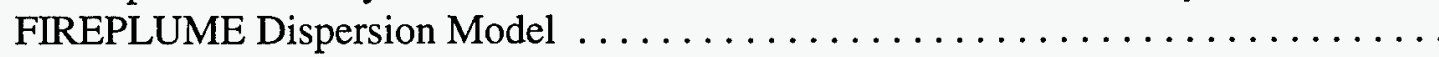

10 Maximum Predicted Contaminant Concentrations in Soil from Deposition and Corresponding Action Levels $\ldots \ldots \ldots \ldots \ldots \ldots \ldots \ldots \ldots \ldots \ldots \ldots \ldots \ldots \ldots \ldots \ldots \ldots$

11 Inhalation Toxicity Values for Contaminants of Concern $\ldots \ldots \ldots \ldots \ldots \ldots \ldots$. 40

12 Screening Action Levels for Contaminants in Air ................... 41

13 Maximum Contaminant Release Concentrations as Predicted by FIREPLUME Compared with Action Levels

A.1 Predicted Normalized Ground-Level Concentrations for Forest Fire, Stability Class A

A.2 Predicted Normalized Ground-Level Concentrations for Forest Fire,

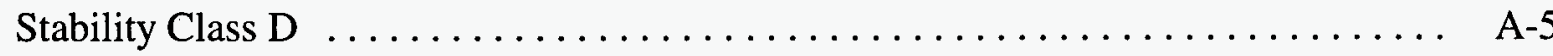

A.3 Predicted Normalized Ground-Level Concentrations for Forest Fire,

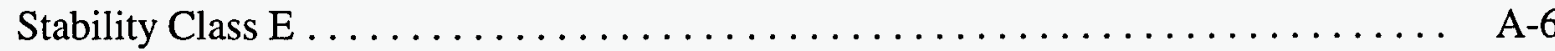

A.4 Predicted Normalized Ground-Level Concentrations for Field Fire, Stability Class A

A.5 Predicted Normalized Ground-Level Concentrations for Field Fire, Stability Class A 


\section{TABLES (Cont.)}

A.6 Predicted Normalized Ground-Level Concentrations for Field Fire, Stability Class E ................................ A

B.1 Emission Concentrations of Constituents in Smoke Condensates of Various Fuels . .

\section{FIGURES}

1 Map of Aberdeen Proving Ground and Surrounding Area $\ldots \ldots \ldots \ldots \ldots \ldots$ C-3

2 Locations of Firing Ranges at APG $\ldots \ldots \ldots \ldots \ldots \ldots \ldots \ldots \ldots \ldots \ldots \ldots$

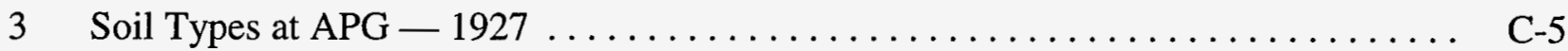

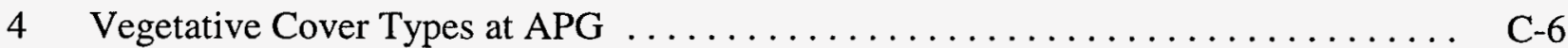

5 Locations of Past Range Fires at APG $\ldots \ldots \ldots \ldots \ldots \ldots \ldots \ldots \ldots \ldots \ldots \ldots \ldots \ldots$

6 Location of Range Fires at Spesutie Island Portion of APG $\ldots \ldots \ldots \ldots \ldots \ldots$ C-8

7 Locations of Range Fires at Aberdeen Area of APG ................. C-9

8 Location of Range Fires at Edgewood Area of APG $\ldots \ldots \ldots \ldots \ldots \ldots \ldots \ldots$ C-10

9 Size Distribution of Reported Range Fires at APG $\ldots \ldots \ldots \ldots \ldots \ldots \ldots \ldots$ C-11

10 Locations of Potential Contaminant Source Sites in the J-Field Study Area $\ldots \ldots \ldots$ C-12

11 Pathways of Contaminants from Testing Projects ................. C-13

12 Cross Section of Smoke Plume for Stability Class A Conditions $\ldots \ldots \ldots \ldots \ldots . . . .6-14$

13 Cross Section of Smoke Plume for Stability Class D Conditions . . . . . . . . . . . C-15

14 Cross Section of Smoke Plume for Stability Class E Conditions $\ldots \ldots \ldots \ldots \ldots$ C-16

15 Map Showing Distribution of Predicted Ground-Level Arsenic Concentrations . . . . C C-17 


\section{NOTATION}

\section{ACRONYMS}

$\begin{array}{ll}\text { AA } & \text { Aberdeen Area } \\ \text { APG } & \text { Aberdeen Proving Ground } \\ \text { ATSDR } & \text { Agency for Toxic Substances and Disease Registry } \\ \text { CR } & \text { plant-to-soil contaminant concentration ratio } \\ \text { DSHE } & \text { Directorate of Safety, Health, and Environment } \\ \text { EA } & \text { Edgewood Area } \\ \text { GPC } & \text { General Physics Corporation } \\ \text { MCLDM } & \text { Monte Carlo Lagrangian Dispersion Model } \\ \text { NBC } & \text { nuclear, biological, and chemical } \\ \text { NPL } & \text { National Priorities List } \\ \text { PEL } & \text { permissible exposure level } \\ \text { RAB } & \text { Restoration Advisory Board } \\ \text { RfC } & \text { reference concentration } \\ \text { RfD } & \text { reference dose } \\ \text { RPDG } & \text { Robbins Point Demolition Ground } \\ \text { TBP } & \text { Toxic Burning Pits } \\ \text { UXO } & \text { unexploded ordnance }\end{array}$

\section{CHEMICALS}

$\begin{array}{ll}\text { As } & \text { arsenic } \\ \mathrm{CG} & \text { carbonyl chloride }\left(\mathrm{COCl}_{2}\right) \text { (phosgene) } \\ \mathrm{DDT} & \text { dichlorodiphenyltrichloroethane } \\ \mathrm{DU} & \text { depleted uranium } \\ \mathrm{HD} & \text { mustard (agent) } \\ \mathrm{Pb} & \text { lead } \\ \mathrm{TCE} & \text { trichloroethylene } \\ \mathrm{U} & \text { uranium }\end{array}$

\section{UNITS OF MEASURE}

$\begin{array}{llll}\text { cal } & \text { calorie(s) } & \mathrm{cm} & \text { centimeter(s) } \\ \mathrm{Ci} & \text { curie(s) } & \mathrm{cm}^{3} & \text { cubic centimeter(s) } \\ \mu \mathrm{Ci} & \text { microcurie(s) } & \mathrm{d} & \text { day(s) } \\ \mathrm{pCi} & \text { picocurie(s) } & { }^{\circ} \mathrm{C} & \text { degree(s) Celsius }\end{array}$




$\begin{array}{ll}\mathrm{ft} & \text { foot (feet) } \\ \mathrm{ft}^{2} & \text { square foot (feet) } \\ \mathrm{g} & \text { gram(s) } \\ \mathrm{in} . & \text { inch(es) } \\ \mathrm{kg} & \text { kilogram(s) } \\ \mathrm{km} & \text { kilometer(s) } \\ \mathrm{L} & \text { liter(s) } \\ \mathrm{dL} & \text { deciliter(s) } \\ \mathrm{m} & \text { meter(s) }\end{array}$

$\begin{array}{ll}\mu \mathrm{m} & \text { micrometer(s) } \\ \mathrm{m}^{3} & \text { cubic meter(s) } \\ \mathrm{mg} & \text { milligram(s) } \\ \mathrm{mi} & \text { mile(s) } \\ \mathrm{min} & \text { minute(s) } \\ \mathrm{mph} & \text { mile(s) per hour } \\ \mathrm{ppm} & \text { part(s) per million } \\ \mathrm{s} & \text { second(s) } \\ \mathrm{yr} & \text { year(s) }\end{array}$




\title{
POTENTIAL HEALTH IMPACTS FROM RANGE FIRES AT ABERDEEN PROVING GROUND, MARYLAND
}

\author{
by \\ G.P. Williams, A.M. Hermes, A.J. Policastro, \\ H.M. Hartmann, and D. Tomasko
}

\begin{abstract}
This study uses atmospheric dispersion computer models to evaluate the potential for human health impacts from exposure to contaminants that could be dispersed by fires on the testing ranges at Aberdeen Proving Ground, Maryland. It was designed as a screening study and does not estimate actual human health risks. Considered are five contaminants possibly present in the soil and vegetation from past human activities at APG - lead, arsenic, trichloroethylene (TCE), depleted uranium (DU), and dichlorodiphenyltrichloroethane (DDT); and two chemical warfare agents that could be released from unexploded ordnance rounds heated in a range fire - mustard and phosgene. For comparison, dispersion of two naturally occurring compounds that could be released by burning of uncontaminated vegetation - vinyl acetate and 2-furaldehyde - is also examined. Data from previous studies on soil contamination at APG are used in conjunction with conservative estimates about plant uptake of contaminants, atmospheric conditions, and size and frequency of range fires at APG to estimate dispersion and possible human exposure. The results are compared with U.S. Environmental Protection Agency action levels. The comparisons indicate that for all of the anthropogenic contaminants except arsenic and mustard, exposure levels would be at least an order of magnitude lower than the corresponding action levels. Because of the compoundingly conservative nature of the assumptions made, we conclude that the potential for significant human health risks from range fires is low. We recommend that future efforts be directed at fire management and control, rather than at conducting additional studies to more accurately estimate actual human health risk from range fires.
\end{abstract}




\section{INTRODUCTION}

Aberdeen Proving Ground (APG), a major U.S. Army testing facility, is located at the northern end of Chesapeake Bay, mostly in Harford County, Maryland. Two small sections on the western edge of the installation are in Baltimore County, Maryland (Figure 1). ${ }^{1}$ Kent County, Maryland, is across the bay to the east, and Cecil County, Maryland, is north of APG. Baltimore, the nearest major city, is about $10 \mathrm{mi}(16 \mathrm{~km})$ west of the northwestern boundary of APG.

APG has a long history as a U.S. Army site for testing artillery and other ordnance, military vehicles, and a variety of other military equipment. The site also includes the principal U.S. Army mechanical maintenance training facilities and serves as the home base for the Maryland National Guard. More than 70 tenant organizations with more than 300 individual mission activities are located at APG.

In the testing and training range areas at APG, fires are occasionally caused by ordnance firing or lightning strikes. Because of APG's long history of weapons testing, there is concern that contaminants have accumulated in the soils and vegetation and could be transported in the smoke plumes produced by such fires to pose a health risk to exposed individuals on and off the site. This study considers the mobilization, transport, and deposition of contaminants produced by range fires and potential health risks of those contaminants. Sources of contamination include residues in and on vegetation from previous weapons testing and chemicals released from burning uncontaminated vegetation and detonation of unexploded ordnance (UXO). Contaminants of concern for this study were selected in consultation with APG personnel and public oversight groups and include arsenic (As), lead $(\mathrm{Pb})$, depleted uranium (DU), trichloroethylene (TCE), dichlorodiphenyltrichloroethane (DDT), vinyl acetate, 2-furaldehyde, and mustard and phosgene chemical agents in UXO.

Although this study did evaluate potential human health risks, the primary objective was to conduct a broad screening to identify important physical and chemical processes that might impact human health and to determine whether a need exists to collect more data or to further study the impact of range fires on human health. In this study, information from previous research at APG was combined with computer modeling to generate a credible worst-case scenario and determine an upper bound for the human health risks that might result from range fires.

Because this study is preliminary and designed to determine the need for a more refined approach, the modeling did not calculate total risk to the population surrounding APG. However, a comparison of the predicted downwind contaminant concentrations to the screening guideline concentrations for each chemical allows the generation of preliminary impact assessments for receptors on and off APG. The bounding-case scenarios modeled consider a "most-exposed"

1 All figures appear at the end of the document in Appendix C. 
individual located at the point of highest contaminant concentration for the duration of the fire. This same receptor would also be present at the point of highest concentration for all subsequent fires.

The remainder of this document discusses the environmental setting at APG, source terms for potential contamination, transport modeling for the contaminants of concern, and comparisons of model-predicted exposure levels with screening action levels based on human health risk.

The environmental setting at APG, as it relates to this study, is summarized in Section 2, and information on characteristics of range fires at the facility is provided in Section 3. Contaminants of concern are identified in Section 4, and their chemical characteristics are outlined in Section 5. Sections 6 and 7 present information on biomass and plant uptake of contaminants that is used in the calculation of contaminant releases during a range fire. Modeling of contaminant releases from burning of contaminated and uncontaminated vegetation is discussed and results presented in Section 8 , and similar information for release of chemical agent contaminants from UXO during a range fire is presented in Section 9. Potential human health risks from the calculated contaminant releases are discussed in Section 10. Section 11 discusses the study results, and Section 12 presents the investigators' recommendations. Finally, references cited in the report are listed in Section 13. Supporting data are presented in Appendix A (FIREPLUME Model Results) and Appendix B (Emission Factors for Burning Vegetation). Figures and illustrations cited in the text are presented in Appendix C. 


\section{ENVIRONMENTAL SETTING}

APG consists of two main areas: the Aberdeen Area (AA) and the Edgewood Area (EA) (Figure 1). Both areas were acquired by the government in 1917. Ammunition testing began at the Aberdeen Area in 1918; more than 400,000 rounds of ammunition were test fired that year. During World War II, the reservation grew with the acquisition of about 5,000 acres at Spesutie Island and the present Churchville Test Area. The Aberdeen Area now includes approximately 25,000 acres and consists of three major subareas: the headquarters and research area, the training and support area, and the test range area. The latter area comprises about $80-85 \%$ of the Aberdeen Area and includes 46 firing ranges (Figure 2), impact areas, vehicular test courses, and munitions storage areas (Davis 1990).

The Edgewood Area includes Gunpowder Neck peninsula between the Bush and Gunpowder Rivers (Figure 1), comprising about 10,000 acres. Carroll Island and Grace's Quarter in Baltimore County are also part of the Edgewood Area and cover an additional 1,200 acres. The Edgewood Area was acquired by the government in 1917 and was first known as Gunpowder Reservation. It became the Edgewood Arsenal in 1918. The installation was designed to produce chemical warfare agents and included gas manufacturing facilities, shell-filling plants, barracks, and artillery ranges. Most of its initial chemical production activities ended with the end of World War I. During World War II, chemical manufacturing was reinstituted, and new manufacturing facilities were developed. Following the war, manufacturing activities at Edgewood were reduced, and research and development missions were emphasized.

Land use in the Edgewood Area is less structured and more spatially disjointed that in the Aberdeen Area. Major functional areas include five firing ranges, a cantonment area, an industrial area, a training area, and a research and development area.

In total, the firing ranges at APG cover approximately 33,000 acres, of which 12,000 acres are covered by water, 4,000 acres are swampy, and 17,000 acres are vegetated uplands. Vegetation control is practiced only along roadways and at firing points; however, 400 acres are routinely cleared to facilitate recovering ordnance rounds (Rynders 1995).

\subsection{CLIMATE AND METEOROLOGY}

The climate at APG is humid, continental. It is characteristically warm, temperate, and rainy; there is no dry season. The summer months have frequent afternoon and evening thunderstorms associated with the warm, moist air from the south. Yearly precipitation averages about 42 in. (Davis 1990). Prevailing winds are from the west to northwest, except in the summer 
months, when the winds are more southerly. The average wind speed is $10 \mathrm{mph}$; velocities of between 50 and $60 \mathrm{mph}$ occur only during severe thunderstorms (Davis 1990).

\section{$2.2 \mathrm{SOIL}$}

Soils at APG are deep and moderately well drained to well drained. Soils that dominate the upland areas are Sassafras, Elkton, Beltsville, Loamy and Clayey Land, and Matapeake-Mattapex Series (Figure 3). The material beneath the surficial soils ranges from sandy, loamy, gravelly, to clayey (Hlohowskyj et al. 1996). Because of high precipitation and the draining capacity of the soils, contaminants could leach through the soil profile and be less available for plant uptake.

Some localized areas of soil at APG are highly contaminated with chemicals such as metals (Jastrow 1995; Hlohowskyj et al. 1996). Before the inception of APG, the land areas were used primarily for agriculture. Some agricultural activities, such as fertilization, may have led to low-level chemical contamination of the soil, depending on the type and quantity of fertilizers and pesticides used. Additional contamination has occurred because of years of weapons testing and munitions disposal operations. Chemical contamination of the soil in some areas is significant and exceeds state or federal standards (Directorate of Safety, Health, and Environment [DSHE] 1994). Areas with such contamination are localized and associated with past range operations. Although the full extent of soil contamination is not known, the soil quality in several locations at APG has been well characterized.

\subsection{VEGETATION}

APG can be divided functionally into two types of zones: security zones (range and test track areas) and developed zones (cantonment, industrial, training, and research and development areas). Large portions of the security zones are not actively landscaped or significantly disturbed by mission activities and contain a variety of terrestrial, wetland, and aquatic vegetation (SWCA 1994). The developed zones in both the Aberdeen Area and the Edgewood Area contain a total of about 7,800 acres of landscaped lawns, buildings, airfields, golf courses, and troop training areas. The extent of vegetative cover types for the various areas at APG is detailed in Table 1.

Much of the Aberdeen Area consists of wetland and forest, although all of the other cover types are also present to some extent. The Edgewood Area is also covered primarily with wetlands and forests. Most of the forested land is within security zones and consists of typical eastern hardwood, pine, and scrub pine species. Approximately 13,000 acres of APG is forested. The most common trees are oak, sweetgum, maple, cherry, and loblolly pine (Davis 1990). These forests contain mostly medium to large trees (15- to 24-in. diameter at breast height [about $4 \mathrm{ft}$ ]). Many of these trees are mature and generally lack an understory (U.S. Department of the Army 1987). 
TABLE 1 Vegetation and Land Cover Areas (acres) at APG

\begin{tabular}{lccccccc}
\hline \multicolumn{1}{c}{ Location } & Forest & Lawn & Old-Field & $\begin{array}{c}\text { Short } \\
\text { Grass } \\
\text { Ranges }\end{array}$ & Wetlands & Bare Soil & $\begin{array}{c}\text { Buildings } \\
\text { and Roads }\end{array}$ \\
\hline Aberdeen Area & & & & & & & \\
Developed & 564 & 1,372 & 50 & 0 & 165 & 51 & 588 \\
$\quad$ Security & 8,154 & 1,148 & 3,426 & 574 & 8,848 & 389 & 623 \\
Edgewood Area & & & & & & & \\
$\quad$ Developed & 1,232 & 1,154 & 130 & 0 & 282 & 11 & 511 \\
$\quad$ Security & 2,423 & 0 & 720 & 694 & 2,343 & 120 & 42 \\
Grace's Quarters & 229 & 0 & 67 & 0 & 162 & 0 & 0 \\
Carroll Island & 44 & 0 & 70 & 0 & 711 & 0 & 0 \\
Pooles Island & 113 & 0 & 15 & 0 & 69 & 0 & 0 \\
Spesutie Island & 209 & 512 & 1 & 0 & 1,006 & 1 & 57 \\
Total & 12,969 & 4,186 & 4,479 & 1,268 & 13,586 & 572 & 1,820 \\
\hline ancludes forested wetlands. & & & & & & \\
Source: Unpublished information, Argonne National Laboratory.
\end{tabular}

Old-field habitat occurs in scattered locations throughout APG. These areas are infrequently mowed and are dominated by grasses and other herbaceous species that are 1 to $3 \mathrm{ft} \mathrm{high}$. These fields occupy approximately 5,750 acres, or $15 \%$ of the land area at APG. Common species in these areas include bluegrass, timothy, yarrow, goldenrod, plantain, and bromegrass. Woody species such as blackberry, honeysuckle, and grape often invade these areas. Although old-field habitat is maintained in some test ranges and in other areas by occasional mowing and burning, the number of infrequently mowed areas increased from $19 \%$ to $23 \%$ between 1976 and 1985 . These areas can be mowed up to twice a year, or often not at all (General Physics Corporation [GPC] 1992).

Cover types in existing range areas can be divided into the same categories discussed above. Table 2 presents specific breakdowns for the various types of range cover. The locations and spatial distribution of different range cover types at APG are detailed in Figure 4. The vegetation types shown in Figure 4 are bare earth, forest, field (both frequently and infrequently mowed), and marsh/shrub. 
TABLE 2 Cover Types and Current Range Areas (acres)

\begin{tabular}{lcccccccc}
\hline & \multicolumn{1}{c}{$\begin{array}{l}\text { Short } \\
\text { Grass } \\
\text { Range Type }\end{array}$} & Forest & Lawn & Old-Field & $\begin{array}{l}\text { Ranges } \\
\text { Bare }\end{array}$ & $\begin{array}{l}\text { Wuildings } \\
\text { and Roads }\end{array}$ & Water \\
\hline Eirect fire & 2,057 & 55 & 1,317 & 184 & 3,783 & 39 & 30 & 2,298 \\
Indirect fire & 2,164 & 107 & 1,358 & 237 & 4,073 & 63 & 51 & 13,913 \\
Static detonation & 2,762 & 346 & 767 & 624 & 2,738 & 172 & 111 & 2,426 \\
$\begin{array}{l}\text { Impact and } \\
\text { recovery fields }\end{array}$ & 37 & 0 & 235 & 155 & 148 & 130 & 1 & 0.3 \\
\hline
\end{tabular}




\section{FIRES AT APG}

Historical information about range fires that have occurred on APG over a 62-month period (January 1992-March 1997) was used to develop a database for this study. ${ }^{2}$ The information was taken from the APG Fire Department records. Over that period, 393 range fires were recorded. These fires were classified as "natural cover fire," "brush fire," "field fire," or "range fire" by the Fire Department. These classifications appear to have been arbitrarily assigned by the personnel who filed the reports.

\subsection{LOCATIONS}

The approximate locations of the range fires reported are plotted (as dots) on maps in Figures 5-8. Although some indication of each fire location was given in individual reports, the specificity varied significantly among fires. For fires occurring on firing ranges, if the approximate location on the range was indicated, the fire location was plotted on or near that spot on the map. When only the range name was given, a point within the range was chosen. This point was selected to be in an area that did not overlay an existing data point. The same rules applied when a fire location was given only in terms of a designated field, testing area, or road on or near which the fire occurred. Points were selected in an attempt to represent several possible fire locations. A serious limitation to the method by which locations were chosen in cases when detailed information was not available is that locations may appear to have been in an area of vegetative cover that was inconsistent with the type that the fire actually burned. The effect of this uncertainty in locations has no impact on the worst-case analysis because the type of vegetation cover was assumed to be either forest or grassland (for those analyses see Section 6).

Fire department records do not specify the type of vegetative cover burned in every fire. In many cases, several types of vegetation are present in one field. If the area chosen from the fire description contained any part that was categorized as bare soil, the fire point was placed in another vegetation type within the same area.

\subsection{SIZE}

The areal extent of each fire was estimated from the APG Fire Department reports. Very little specific information was given about the size of each fire in those reports. About 120 out of 393 (31\%) reported fires were designated as "small," "moderate," or "large." No information is available

\footnotetext{
2 Fires in or adjacent to buildings were not included in the database because they are not relevant to the range areas.
} 
for delineating the size classifications. Of the fires classified, $14 \%$ were large, $0.3 \%$ ( 1 fire) was moderate, and about $86 \%$ were small.

Actual size estimates were given for only 31 of the reported range fires. The average size of these fires was 4 acres, and the range was from $22 \mathrm{ft}^{2}(0.0005$ acre) to 25 acres. Fifty-eight percent of the classified fires were less than one acre in size $\left(43,560 \mathrm{ft}^{2}\right)$, and $84 \%$ were less than five acres (Figure 9).

For this study, a worst-case fire was assumed to burn 25 acres $\left(1.1\right.$ million $\left.\mathrm{ft}^{2}\right)$, although the actual fire records indicate that only two fires this large occurred during the 62-month period of record.

\subsection{DURATION}

The duration of a typical range fire at APG has decreased since 1994, when helicopters started being used to fight fires. Because of the presence of UXO on the ranges, firefighters are not permitted to leave the road to fight a fire. If a fire cannot be reached from the road, the fire is declared to be in a "dudded" area. Before 1994, the fire would have been left to burn out naturally. However, with the current use of helicopters, water can be dropped from the air until the fire is extinguished.

The average duration of a range fire is now about one hour (Jones 1997); an extreme burning time is five hours. When a fire is extinguished by either land or air, it is typically entirely extinguished to prevent smoldering (Jones 1997).

\subsection{NUMBER AND FREQUENCY}

An estimate of the number of range fires occurring annually at APG was required for the analyses in this study. Although the approximate total of 400 fires that occurred at APG over the 1992-1997 period represents an average of 80 fires per year, 84\% of these fires involved less than 5 acres. The worst-case scenario analyzed for this study involves a 25 -acre fire. Fires of this size constituted only about $2 \%$ of the total fires reported at APG, but they made up approximately $7 \%$ of the fires with a reported size. We assumed that this difference reflects a tendency by Fire Department personnel to estimate the size only for larger fires. For the purposes of this study, we assumed that all fires matched this distribution pattern ( $7 \%$ of fires cover about 25 acres). Because the average number of fires in a year is approximately 80 , it was assumed that about five 25 -acre fires occur per year. This assumption also accounts for all of the biomass burned in the smaller fires, most of which are less than an acre in size. This assumption overestimates the total acreage burned in a given year at 125 acres and contrasts with historical records, which report only two fires of this 
size during the 62-month study period. As detailed in Section 7.2, the total acreage burned by a fire is the most significant input into the models used for this study because the most exposed individual is assumed to be present at the point of highest contaminant concentration for the entire duration of each fire. 


\section{CONTAMINANTS OF CONCERN}

Five chemical contaminants derived from range activities (arsenic, lead, DU, TCE, and DDT) and two contaminants released by burning uncontaminated vegetation (2-furaldehyde and vinyl acetate) were examined in this study. In addition, two chemical agents (mustard and phosgene) were also evaluated.

The two chemical agents would be released from UXO on the ranges if the UXO items were "cooked off" or detonated by the heat generated during a range fire. Unlike the other contaminants, these chemical agents were not assumed to have entered the vegetation. Instead, the maximum credible release of each chemical from one ordnance round was estimated in consultation with APG employees (Anderson 1997). These amounts were then used as input into a contaminant transport and dispersion model, D2PC, often used by the Army for calculating contaminant release and transport for such occurrences.

Although actually an unknown factor, the frequency with which unexploded rounds detonate or rupture during a range fire is expected to be small for at least two reasons. First, large areas of the ranges are covered by water or swamps, which insulate unexploded rounds from heat. Second, rounds lying on a dry surface will probably not be exposed to the fire for enough time to permit heat transfer through the shell casing to cause heat-sensitive areas to reach sufficiently high temperatures to detonate or rupture.

For this study, the temperature of the fire was assumed to be sufficient to detonate the unexploded rounds. No effort was made to determine the probability that a given type of fire would cook-off a UXO round. As a worst-case scenario, the probability of this occurrence was assumed to be 1.0. APG Fire Department records do not indicate that any chemical agent rounds have actually been detonated by range fires during the study period; therefore, the actual probability of such an occurrence is likely to be significantly below the value of 1.0 that we assumed for this study.

\subsection{SOIL CONCENTRATIONS}

Chemical contaminants of concern assumed to be found in and on vegetation at APG include lead, arsenic, TCE, DU, and DDT. For the purpose of this study, it was necessary to estimate the amounts of such chemicals that would be released during a range fire. Information on the soil concentrations of these chemicals was used in these estimates. The information was obtained from several studies previously completed at APG. The concentrations used in this study are listed in Table 3. These values represent high, but realistic, concentrations known for APG soils. 
For several reasons, J-Field was chosen as the representative site for obtaining contaminant levels for lead and arsenic. J-Field is heavily contaminated with metals, extensive soil contamination and vegetation data are available, and plant-uptake studies for several of the contaminants of concern have been conducted at J-Field.

J-Field is located on the southern end of the Gunpowder Neck peninsula within the Edgewood Area of APG (Figure 1). Since the 1940s, J-Field has been the location of many open burning and detonation activities for APG. Figure 10 illustrates the locations of chemical contaminant sources at J-Field. Sampling at J-Field has shown that the soils are highly contaminated with many inorganic compounds (mostly metals) and organic compounds (Yuen et al. 1996).

Samples of soil and plants were
TABLE 3 Contaminant Concentrations in Soil at APG

Contaminant Concentration $(\mathrm{mg} / \mathrm{kg})$

Lead $^{\mathrm{a}}$ 351

Arsenic $^{\mathrm{a}}$ 24

$\mathrm{TCE}^{\mathrm{b}}$

$\mathrm{DU}^{\mathrm{c}}$ 41.5

DDT $^{\mathrm{d}}$ 0.0022

${ }^{a}$ Lead and arsenic soil concentrations obtained from Jastrow (1995).

b TCE soil concentration from Hlohowskyj et al. (1996).

c The DU concentration from Ebinger et al. (1996), converted to $\mathrm{mg} \mathrm{U} / \mathrm{kg}$ soil on the basis of the activity of $0.4 \mu \mathrm{Ci} / \mathrm{g}$ : $16.6 \mathrm{pCi} / \mathrm{g}$ soil $\times 1 / 0.4 \mu \mathrm{Ci} / \mathrm{g} \mathrm{U}=4.15$ $\times 10^{-5} \mathrm{~g} \mathrm{U} / \mathrm{g}$ soil $=41.5 \mathrm{mg} / \mathrm{kg}$.

${ }^{d}$ DDT soil concentration is from General Physics Corp. (1997). analyzed for contaminant levels in a bioremediation study done in the marsh and upland areas near the Toxic Burning Pits (TBP) area at J-Field (Jastrow 1995). The average lead and arsenic concentrations reported in that study were used for the current analysis (Table 3). The arsenic concentration is total arsenic in the soil, whereas the lead concentration represents only the lead that is in the soil solution and available for uptake by plant roots. The Jastrow study, along with others, demonstrated that there is a positive correlation between lead concentrations in plants and available lead concentrations in the soil, but not with total lead in the soil (Jastrow 1995). However, a direct relationship between plant arsenic concentrations and both soluble and total arsenic in the soil is often seen in arsenic studies (Kabata-Pendias 1992).

Soil samples collected at J-Field in 1996 (Hlohowskyj et al. 1996) provided the soil TCE concentration used for this study (Table 3). The DU soil concentration values given in Table 3 were obtained from a previous health assessment study that specifically examined DU at APG (Ebinger et al. 1996). On the basis of the distribution of DU concentrations, the mean DU soil concentration of $16.6 \mathrm{pCi} / \mathrm{g}$ was used for this range fire study. The mean value was used as an upper bound for the 125 contaminated acres assumed to be burned in range fires each year. DDT concentrations were obtained from a recent study at Carroll Island (General Physics Corp. 1997). 
Other lead, arsenic, and TCE values are also reported in the Remedial Investigation Report for J-Field (Yuen at al. 1996) and other studies performed for the entire APG. The average contaminant concentrations given in those reports are consistently lower than the values given in Table 3. On the other hand, individual samples exceeding the values listed in Table 3 were also reported. Of note were the extremely high concentrations found inside the TBP of J-Field. These high values from the TBP were considered to be overly conservative for use in this study for several reasons: (1) areas contaminated to this degree are smaller than the 125-acre area assumed in our study to be burned each year, (2) the TBP area is considered the most contaminated area of J-Field, and possibly of the entire Aberdeen Area, and thus is not representative of conditions elsewhere at APG, (3) none of the metal contamination was present in extractable form, and (4) the highest soil concentrations were often found in areas that do not sustain vegetation and would not, therefore, be releasing contaminants through burning of vegetation.

\subsection{CHEMICALS RELEASED FROM BURNING VEGETATION}

The two chemicals released during burning of uncontaminated vegetation that could produce notable health concerns if emitted in sufficiently high concentrations are 2-furaldehyde and vinyl acetate (Table 4). Information about chemical releases from burning uncontaminated vegetation (Appendix B) was obtained from a study measuring such emissions on a per unit of biomass basis (McKenzie et al. 1995). Separate estimates of contaminant releases were made for forest and field land cover types on the basis of release amounts calculated for burning wood and litter, respectively. Because these data were not specifically obtained for the forest type found at APG, all of the release amounts were multiplied by a factor of five to provide conservative estimates for the vegetation occurring at APG (Richards 1997).

Relative to the release of contaminants of concern from burning contaminated vegetation, all of the arsenic, lead, TCE, DU, and DDT present in a plant was assumed to be released during a range fire. The amount of each contaminant present in the vegetation was estimated by using the plant uptake ratios discussed in Sections 5 and 7. This assumption (release of all contaminants from a plant) means that no residual metal contamination would be left in the ash; all the metal would be released to the fire plume. The assumption was also made that the fire would not degrade or destroy the organic contaminants. These assumptions result in release estimates for these contaminants that are higher than might actually be expected to occur. On the other hand, these assumptions ignore any breakdown products that might be harmful. Ignoring breakdown products was considered to be justifiable because any quantities of breakdown products would be at lower concentrations than the parent chemical. 


\subsection{CHEMICALS RELEASED FROM UXO DETONATION}

Upon recommendation of the APG Directorate of Safety, Health and Environment (DSHE) and the APG Restoration Advisory Board (RAB), the chemicals mustard and phosgene were evaluated for potential release from detonating or rupturing UXO during a fire. The likelihood of such an occurrence (fire detonation or rupture of UXO) is unknown, and calculating the probability or frequency of such an occurrence was beyond the scope of this project. For the purpose of creating a worst-case scenario, it was assumed that a UXO round would be located in the fire area and that the heat of the range fire would detonate that round. Such an event was assumed to occur once a year at APG. The maximum credible releases used for this study are $12.72 \mathrm{~kg}$ of phosgene from a Livens projectile and $2.72 \mathrm{~kg}$ of mustard from a 4.2-in. mortar round (Anderson 1997).
TABLE 4 Source Values for

Chemicals Released from Burning Vegetation ${ }^{\text {a }}$

\begin{tabular}{lc}
$\begin{array}{c}\text { Cover Type/ } \\
\text { Chemicals }\end{array}$ & $\begin{array}{c}\text { Mass } \\
\text { Released (kg) }\end{array}$ \\
\hline & \\
Forest & \\
2-Furaldehyde & 8,080 \\
Vinyl acetate & 29,600 \\
Field & \\
2-Furaldehyde & 292 \\
Vinyl acetate & 143 \\
\hline
\end{tabular}

a Emissions are estimated on the basis of emission factors of components in smoke condensates (McKenzie et al. 1995), multiplied by the total biomass estimated for this study in each cover type. 


\section{CHEMICAL CHARACTERISTICS}

The following sections describe the chemical properties of the seven contaminants of concern in this analysis: arsenic, lead, depleted uranium, trichloroethylene (TCE), dichlorodiphenyltrichloroethane (DDT), mustard agent, and phosgene.

\subsection{ARSENIC}

Arsenic exists in four different oxidation states in the natural environment; it typically occurs in the divalent state in soil solution. Behaving similarly to phosphate, it is fixed (taken from a readily available form to a less readily available form) in the soil by iron, aluminum, and calcium (Berry and Wallace 1974; Dvorak et al. 1978).

Arsenic moves down through the soil column with leaching water in sandy soils. The strong sorption by clays, hydroxides, and organic matter greatly limits this migration (Kabata-Pendias 1992). Background arsenic concentrations at APG range from 0.25 to $3.7 \mathrm{mg} / \mathrm{kg}$ (ICF-Kaiser

Engineers 1995). Arsenic soil contamination at the TBP area may be the result of the disposal and decontamination of lewisite and adamasite - chemical agents used during WWI (Hlohowskyj et al. 1996). Uptake of arsenic by plants has been perceived as a passive process in which the arsenic moves along with water flow into the plant. As a result, linear relationships between plant concentrations and soil concentrations have been observed for both total and soluble forms of the metal. With increasing concentrations of arsenic in the soil, the highest arsenic concentrations within the plant are found in old leaves and roots (Kabata-Pendias 1992).

Arsenic toxicity depends on its chemical form and oxidation state, inorganic forms generally being more toxic than organic forms (Eisler 1988a). In humans, high oral doses (e.g., greater than about $0.3 \mathrm{ppm}$ in food or water) can cause a variety of adverse health effects, such as irritation of the stomach and intestines, decreased production of blood cells, and abnormal heart rhythms. Doses greater than about $60 \mathrm{ppm}$ can cause death (ATSDR 1993a). Chronic low-level oral exposures are associated with increased incidence of cancer of the liver, bladder, kidney, and lung; increased lung cancer incidence is also associated with inhalation of inorganic arsenic. Inorganic arsenic is classified as a known human carcinogen by the U.S. Environmental Protection Agency (EPA 1997).

\subsection{LEAD}

Lead is a common contaminant at munition demolition sites. At J-Field, it is widely distributed in the Pushout Areas of the TBP (Hlohowskyj et al. 1996). 
Lead is much less mobile than other metals, such as arsenic, and is typically unavailable to plants. Relative metal solubility decreases with increasing total metal content of the soil and higher soil $\mathrm{pH}$ because a decrease in soil $\mathrm{pH}$ (increase in soil acidity) also decreases the adsorption of metal to soil particles, thereby making the metal more mobile and possibly more available for plant uptake (Kabata-Pendias 1992).

Lead often moves down through the soil column with water, but generally remains bound within the top few feet of soil. The characteristic localization of this metal near the soil surface often depends on the accumulation of organic matter, which binds the metal, at shallow depths (Yuen et al. 1996).

Plants are able to uptake lead from the soil when it is in solution. Generally, a direct relationship exists between an increasing amount of lead in the plant tissue and the amount of available, or soluble lead, in the soil solution (Kabata-Pendias 1992; Jastrow 1995). Lead typically accumulates in the roots of plants, with very limited translocation to plant tops. Results of studies of Phragmites australis at J-Field corroborated the direct relationship between plant lead concentrations and available lead in the soil. The calculated plant:soil concentration ratios are up to an order of magnitude higher for roots than plant tops, emphasizing the limited translocation of lead to aboveground plant parts (Jastrow 1995).

Lead deposition on plant surfaces usually does not affect transpiration across a plant's lipophilic surface; however, lead volatilization may decrease during a fire (Eisler 1988b). Because of precipitation, however, the lead deposited on these plant surfaces could be removed shortly after deposition, and volatilization would not be affected.

Reported effects of lead poisoning in mammals include altered structure and function in kidneys, bones, and the hematopoietic (blood-forming) and central nervous systems, as well biochemical, histopathological, teratogenic, and reproductive effects (Eisler 1988b). High oral or inhalation doses of lead can cause anemia, severely damage the brain and kidneys, damage the male reproductive system, and cause abortions (ATSDR 1993b). Chronic lower-level exposures cause premature births and decreased mental ability in exposed infants and children. Exposures to some inorganic lead compounds have been associated with kidney tumors in rats and mice; inorganic lead compounds are classified as probable human carcinogens by the EPA (1997).

\subsection{DEPLETED URANIUM}

Depleted uranium (DU) is the waste product of uranium enrichment processes and is defined as uranium that has less than $0.711 \%$ of the isotope uranium-235. DU consists principally of uranium-238, with trace amounts of uranium-235. Although it is less radioactive than natural 
uranium, DU metal is pyrophoric (able to ignite spontaneously) and extremely dense (Los Alamos National Laboratory 1996). Military specifications require that DU used by the Department of the Defense (DOD) must have $0.334 \%$ or less uranium-235, and DU actually used by the DOD has only $0.2 \%$ uranium-235 (Rynders 1995).

The DU at APG is derived from the testing of penetrators made of depleted uranium. This testing began in the 1970s. Test firing has been primarily limited to the B-3 Range and Ford's Farm at APG; initial studies were performed primarily for antitank munitions. Testing in 1990 involved the firing of approximately 9,000 rounds (Davis 1990). The penetrators used in the testing are composed of $99.25 \%$ uranium and $0.75 \%$ titanium, by weight, and are constructed of an alloy material called Stallaboy (Davis 1990).

Potential threats to human health from DU are radioactivity and toxic chemical hazards, with the chemical hazards posing the highest risk (Davis 1990). If inhaled in soluble form, compounds of DU can cause chemical toxicity to the kidney. Radioactive dangers are less for compounds of DU than for natural uranium. One gram of natural uranium emits $0.68 \mu \mathrm{Ci}$ of radiation, while DU emits $0.36 \mu \mathrm{Ci}$ of radiation per gram. This difference is due mostly to the removal of radioactive products during the enrichment processes that produce DU (Davis 1990).

\subsection{TRICHLOROETHYLENE}

Trichloroethylene, also trichloroethene, TCE, or TRCLE, is a volatile, halogenated hydrocarbon that was selected as the example solvent for this study. The halogenation of this chemical makes it less flammable, more stable, more hydrophobic, and more troublesome environmentally than other hydrocarbons (Mackay 1991). Its main danger may be a result of its high affinity to partition out of water and into target organisms. This affinity is shown by the compound's octanol-water partition coefficient, or the concentration of the chemical in octanol divided by the concentration of the chemical in water (Travis and Arms 1988). This ratio, which for TCE is 240, serves as a measure of a chemical's lipophilicity, or tendency to partition out of water and into lipids. The higher this ratio, or the more lipophilic a chemical, the greater its chances of passing through the lipid barrier surrounding a plant.

Unlike metals, a major factor with organic contaminants is the age of the contamination, especially for chlorinated solvents like TCE. These contaminants may be affected by phytodegradation, which is the plant-assisted breakdown of the chemical to less or nontoxic degradation products, as well as in-situ degradation in the soil water.

Studies show a direct relationship between the amount of water available to a plant and the uptake of TCE and/or its metabolites (Kabata-Pendias 1992). Uptake of organic compounds from soil by plants is mainly affected by three parameters: (1) the physicochemical properties of the 
compound, (2) the environmental conditions, and (3) the plant characteristics. Assuming that the environmental conditions and plant types are constant across APG, water uptake generally will be the determining factor for the uptake of TCE. Increased water flow increases bulk transport through a plant because of evapotranspiration, which is the driving force behind translocation.

TCE is hydrophobic, and only trace amounts of the compound will dissolve in water. Persistent in nature, its half-life depends entirely on the existing form, which in turn depends on the microbes present. Health hazards associated with TCE include headaches and dizziness when it is inhaled, even in moderate amounts. Animals chronically exposed to TCE can have enlarged livers. TCE has been classified as a possible or probable human carcinogen by the EPA (1996).

\subsection{DDT}

For this study, the anthropogenic pesticide tested was $4,4^{\prime}$-DDT. The source of this chemical at APG was previously widespread spraying for insects and other pests. This source has been eliminated because the use of DDT has been banned in the United States since 1972.

The process of DDT breakdown in the soil is not completely understood, and some uncertainty exists about the time required for it to occur. Certain studies have indicated that the effective half-life for DDT in the soil is two years; other studies indicate that breakdown of this compound may take more than 15 years. DDT can evaporate from the soil surface and enter the air, or be broken down by the sun (photolysis) and certain microorganisms. DDT does not move readily in the environment, especially in the soil, where it is readily adsorbed to soil particles. It can, however, be taken up by some plants growing in contaminated soils (ATSDR 1992a). DDT volatilizes more readily than its breakdown products and has an estimated volatilization half-life of 100 days (Sleicher and Hopcraft 1984).

DDT and its breakdown products enter the body primarily through ingestion, depending on the concentration in the food consumed. Small amounts can enter the body through the air. However, the particles are usually too large to cross into the lungs and are typically coughed up. DDT exposure generally results in detrimental effects to the nervous system. However, these effects are seen at very high concentrations (on the order of $571 \mathrm{ppm}$ ). No effects have been seen in people exposed to amounts up to $22 \mathrm{ppm}$ for 18 months (ATSDR 1992a). DDT is classified as a probable human carcinogen by the EPA (1997).

\subsection{MUSTARD}

Mustard (HD) is a blister agent that has delayed effects. Most of the HD in mustardcontaining munitions is material that was distilled before loading and, therefore, originally was pure. 
HD that is confined for a long time in sealed containers can undergo thermal degradation to 1,4-dithiane and 1,2-dichloroethane (Bell et al. 1927). The thermal decomposition products of HD increase with time during storage.

The melting point of mustard $\left(58^{\circ} \mathrm{F}\right)$ is high enough that for portions of the year it will be a solid and unable to flow through holes in corroded containers. Even above this melting point, HD may not readily move through corrosion holes, because of the formation of a polymer skin at the water/organic interface.

The primary acute effects of mustard are severe irritation of the eyes and respiratory tract and blistering of the skin. Inhalation and dermal exposure are the primary pathways of concern, because mustard degrades very quickly in water. The Department of Health and Human Services and the International Agency for Research on Cancer have classified mustard as carcinogenic (ATSDR 1992b).

\subsection{PHOSGENE}

Phosgene, $\mathrm{CG}$, or carbonyl chloride $\left(\mathrm{COCl}_{2}\right)$ is an extremely volatile chemical that reacts with water to form hydrogen chloride and carbon dioxide with a half-life of 0.12 second. Therefore, $\mathrm{CG}$ can only survive long term in a sealed container. The main toxic effect of phosgene exposure is pulmonary edema (abnormal accumulation of fluid in the lungs), which often proves fatal. 


\section{BIOMASS INFORMATION/ VEGETATION SURVEYS}

The total quantity of contaminants mobilized by a fire depends on the type of vegetation in the area in which the fire occurs and the types and concentrations of contaminants present in the aboveground plant parts. This section describes the biomass available for contaminant mobilization; Section 7 describes the potential plant uptake for organic and inorganic contaminants of concern.

Biomass estimates were made for the different vegetation types in which fires have occurred at APG. Because of large uncertainties, the various cover types previously described in Tables 1 and 2 were combined into two categories: forest and field.

Because specific information on forest biomass was not available for APG, the data needed for this analysis were estimated on the basis of a typical southeastern United States deciduous forest. Because of the abundance of sweetgum and red maple in the APG area, the representative forest type chosen was defined as "Mixed Hardwood" dominated by the "Acer-Nyssa association." An average aboveground biomass of $7.9 \times 10^{4} \mathrm{~kg} /$ acre has been estimated for this forest type (Barbour and Billings 1988). For the purposes of this study, 100\% of the available biomass was assumed to be consumed by the fire. We assumed that no residues from the contaminants would remain in the ash from the fire. The total amount of forest biomass available for consumption in each fire was estimated on the basis of a fire covering 25 acres; details are provided in Table 5.

All vegetation other than forest was classified as field for biomass calculations. Field biomass estimates were based on previous upland biomass samples taken from J-Field by Hlohowskyj et al. (1996). Field vegetation includes grass species, reeds (typical of marsh and shrub/marsh areas), shrubs, forbs, and other herbaceous species. Data were taken from samples in five areas: the Toxic Burning Pits, South Beach Trench, Robbins Point Demolition Ground, Robbins Point Tower Site, and the Riot Control Pit. The values were averaged for each of the five areas. The maximum average biomass $(2,280 \mathrm{~kg} / \mathrm{acre})$ was measured at the Robbins Point Demolition Ground (RPDG) (Hlohowskyj et al. 1996). The low frequency of mowing in this area (about once a year) permits more biomass to accumulate and increases plant exposure to soil contaminants over that in areas that are more frequently mowed. For this study, all of the field biomass available (Table 5) was assumed to be consumed by the fire, again leaving no contaminant residues in the ash.

Because the biomass information being used is from a heavily contaminated area (J-Field), the question could arise whether the vegetation biomass might be less because of the presence of contamination and its impact on plant growth. As a control, a reference point in an uncontaminated area was chosen to compare biomass production in areas with and without soil contamination (Hlohowskyj et al. 1996). The control study area is in Gunpowder Falls State Park. It was selected because of its similar natural soil conditions and mowing regimen. A Mann-Whitney similarity test completed for that study indicated that the Robbins Point Demolition Ground and the reference point 
TABLE 5 Total Biomass Available for

Consumption in Fire - Forest and Field Areas $^{\mathrm{a}}$

\begin{tabular}{lccr}
\hline $\begin{array}{c}\text { Average } \\
\text { Cover } \\
\text { Type }\end{array}$ & $\begin{array}{c}\text { Maximum } \\
(\mathrm{kg} / \mathrm{acre})\end{array}$ & $\begin{array}{c}\text { Total } \\
\text { Fire Size } \\
\left(\mathrm{F}_{\mathrm{m}}\right)(\mathrm{acres})\end{array}$ & $\begin{array}{c}\text { Biomass } \\
\left(\mathrm{B}_{\mathrm{T}}\right)(\mathrm{kg})\end{array}$ \\
\hline Field & 2,280 & 25 & 57,000 \\
Forest & 79,000 & 25 & $1,980,000$ \\
\hline
\end{tabular}

a The symbols $\mathrm{B}_{\mathrm{a}}, \mathrm{F}_{\mathrm{m}}$, and $\mathrm{B}_{\mathrm{T}}$ are used to represent these parameters in Equation 5 in Section 7.2.

did not significantly differ in the amount of vegetative biomass (Hlohowskyj et al. 1996). This result indicates that the biomass production at RPDG was not significantly affected by soil contamination, and, therefore, the biomass measured there can be used to represent the biomass for the majority of the field areas at APG. 


\section{PLANT UPTAKE AND RELEASE MODELS}

The following sections discuss the methods used to estimate plant uptake of the contaminants of concern and the subsequent release of those contaminants during a range fire.

\subsection{ESTIMATING PLANT UPTAKE OF CHEMICALS}

Soil contaminants can be taken up by plant roots and possibly translocated to aboveground plant tissues (Figure 11). A less significant contribution to total plant contamination can arise from splashing of contaminants in the soil onto plant surfaces by rain (rainsplash). Although equations exist to estimate contamination by rainsplash, the quantities were considered negligible for this case and were, therefore, excluded from our calculations.

Contaminant concentrations in plant tissue were estimated on the basis of known soil concentrations, mathematical uptake models from studies reported in the literature, and field studies done at J-Field (Jastrow 1995). Determining the amount of a contaminant that a plant uptakes is an extremely complex task. Uptake depends on the contaminant's state and characteristics, the physiological parameters of the plant, and the soil and atmospheric conditions (Dvorak et al. 1978; Kabata-Pendias 1992; Hope 1995; Jastrow 1995). The uptake ratios used for this study are in the form of plant:soil uptake ratios. This methodology assumes a linear relationship between contaminant values in the soil and values in the plant tissue. This method may overestimate the uptake at high soil contamination levels, because uptake ratios may be nonlinear. Uptake ratios may be higher for lower soil concentrations and decrease as soil concentrations increase. Any unknown parameters needed for estimating plant uptake were assumed to have values that would result in reasonable maximum uptake.

\subsubsection{Uptake of Inorganic Contaminants}

Many plants have the ability to uptake metals, even those not required as nutrients. In some cases, plants can also accumulate contaminants in their tissue. To uptake and accumulate a metal, plants chelate the metal, which makes it less toxic to the plant, and then move the metal from the roots to the shoots. The highest concentration of metals is generally found in plant roots (Jastrow 1995; Kabata-Pendias 1992), but concentrations in aboveground shoots can be higher. Previous field studies at J-Field did not indicate the presence of any plants that had contaminant concentrations in excess of the soil values. This study focuses on the aboveground plant parts and contaminant concentrations because they are subject to burning in a range fire. 
The following equation (from Hlohowskyj et al. 1996) was used to estimate the concentrations of arsenic, lead, and DU in the aboveground plant parts:

$$
C_{p}=C R \times C_{s} \text {, }
$$

where

$$
\begin{aligned}
& \mathrm{C}_{\mathrm{p}}=\text { contaminant concentration in plant tissue }(\mathrm{mg} / \mathrm{kg}) \text {, } \\
& \mathrm{CR}=\text { plant-to-soil concentration ratio, and } \\
& \mathrm{C}_{\mathrm{s}}=\text { contaminant concentration in the soil }(\mathrm{mg} / \mathrm{kg}) \text {. }
\end{aligned}
$$

The concentration ratio, $\mathrm{CR}$, is defined as the ratio of the average concentration of the contaminant in the plant to the average contaminant concentration in the soil (Dvorak et al. 1978). This method is widely used to estimate plant concentrations on the basis of known soil values. This procedure is commonly used for preliminary studies when detailed plant and soil samples are not available for more sophisticated models. The ratio, however, does not incorporate the differences in soil $\mathrm{pH}$, soil type, cation exchange capacity, plant species, and other environmental conditions that might be different from those used to obtain the $C R$ values. The $C R$ values themselves depend on the type of inorganic compound, as well as on environmental conditions. The highest ratios consistent with APG field conditions were chosen for this study. The assumptions of this uptake model (Vaughn et al. 1975) are as follows:

- $\mathrm{CR}$ values depend on the available contaminant concentration.

- $\quad$ R generally decreases with increasing soil concentration.

- $\mathrm{CR}$ appears to reach a maximum at a low level $(<1 \mathrm{ppm})$, when saturation kinetics are applied, and decreases beyond this point.

- CR values assume that uptake is entirely an energy-dependent process in which plants accumulate ions from solution against a concentration gradient.

- Uptake of a contaminant from the soil remains constant, in excess of the individual saturation point for the plant and chemical. Thus, plant tissue concentrations estimated using this model may exceed actual maximum values for the plant. 
The CR values used here (Table 6) for lead and arsenic ( 0.45 and 0.14 , respectively) were taken from studies by Hodgson (1970). These values are more conservative by an order of magnitude than those listed in the Chemical Database for Multimedia Environmental Assessment System (Strenge and Peterson 1989), which gives values of 0.068 and 0.02 for lead and arsenic, respectively.

Concentration ratios derived from actual plant and soil lead concentrations measured at J-Field confirm the conservative nature of the ratio chosen for lead. In the J-Field bioremediation study, the ratios range from 0.013 to 0.065 for Phragmites australis, a common reed that is known to have high uptake ratios. This ratio is far below the CR of 0.45 for lead used in this study (Jastrow 1995). Although even larger values were available from Vaughn et al. (1975), they were rejected for this study because (1) Vaughn's values were for plants grown under laboratory, hydrophobic conditions and cannot be applied to field conditions, and (2) actual field data are an order of magnitude below the values used for this study.

Higher total plant CR values were used for this study as an upper-bound estimate of plant uptake and reflect root values, even though only the aboveground portion of the plant will be burned. The aboveground plant tissues typically have lower CR values than the total plant values used in this study. This fact is particularly important for estimating lead uptake, because extensive research in the behavior of lead indicates that it accumulates mainly in the roots and nodules, with very little actually translocated to the plant tops (Kabata-Pendias 1992; Jastrow 1995; and Hlohowskyj et al. 1996). Thus, the total plant accumulation is typically much higher than the amount of the contaminant that is available for burning. The ratios calculated in the Jastrow (1995) study were an order of magnitude higher for the roots than those for the shoots.

\section{TABLE 6 Plant Uptake Parameters ${ }^{\mathrm{a}}$}

\begin{tabular}{lccc}
\hline Chemical & $\begin{array}{c}\text { Soil Concentration }\left(\mathrm{C}_{\mathrm{s}}\right) \\
(\mathrm{mg} / \mathrm{kg})\end{array}$ & $\begin{array}{c}\text { Plant-to-Soil } \\
\text { Concentration Ratio }\left(\mathrm{K}_{\mathrm{ps}}\right) \\
(\mathrm{CR})\end{array}$ & $\begin{array}{c}\text { Estimated Plant } \\
\text { Concentration }\left(\mathrm{C}_{\mathrm{p}}\right) \\
(\mathrm{mg} / \mathrm{kg})\end{array}$ \\
\hline Lead & 351 & 0.45 & 158 \\
Arsenic & 24 & 0.14 & 3.36 \\
DU & 41.5 & 0.0025 & 0.104 \\
TCE & 2.8 & 0.32 & 0.896 \\
DDT & 0.0022 & 0.002 & $4.4 \times 10^{-6}$ \\
\hline
\end{tabular}

a Lead and arsenic concentrations ratios (CR) are based on work done by Hodgson (1970). DU CR, TCE $\mathrm{K}_{\mathrm{ow}}$, and DDT $\mathrm{K}_{\mathrm{ow}}$ values (used in calculating $\mathrm{K}_{\mathrm{ps}}$ ) were taken from Strenge and Peterson (1989). $C_{P}$ values are the product of $C_{S}$ and $C R$ (or $K_{p s}$ for organic materials); see Section 7.1. for details and calculations. 
The CR used for DU is 0.0025 (Strenge and Peterson 1989; NCRP 1984; Ebinger et al. 1996). All isotopes from uranium-233 to uranium- 239 were listed with the same uptake ratio. The same caveats and assumptions detailed above also apply to $C R$ values for $D U$.

\subsubsection{Uptake of Organic Contaminants}

Estimated uptakes for the two organic contaminants (TCE and DDT) were calculated with a model in which $\mathrm{CR}$ is replaced by $\mathrm{K}_{\mathrm{ps}} . \mathrm{K}_{\mathrm{ps}}$ is similar to $\mathrm{CR}$ and is a function of the octanol-water partition coefficient $\left(\mathrm{K}_{\mathrm{ow}}\right)$ of the organic contaminant. This model can be expressed as (Hope 1995):

$$
\begin{gathered}
C_{p}=K_{p s} \times C_{S} \\
K_{p s}=7.7 x K_{o w}{ }^{-0.58,}
\end{gathered}
$$

where

$$
\begin{aligned}
\mathrm{C}_{\mathrm{p}}= & \text { contaminant concentration in the plant }(\mathrm{mg} / \mathrm{kg}) \\
\mathrm{C}_{\mathrm{s}}= & \text { contaminant concentration in the soil }(\mathrm{mg} / \mathrm{kg}) \text {, and } \\
\mathrm{K}_{\mathrm{ps}}= & \begin{array}{l}
\text { plant-soil partition coefficient for soil to above-ground plant parts } \\
\text { (unitless). }
\end{array}
\end{aligned}
$$

The $\mathrm{K}_{\mathrm{ow}}$ value for TCE is 240 (Strenge and Peterson 1989), which gives a $\mathrm{K}_{\mathrm{ps}}$ value of 0.32 . The $\mathrm{K}_{\mathrm{ow}}$ for DDT is $1.6 \times 10^{6}$ (Strenge and Peterson 1989); the associated $\mathrm{K}_{\mathrm{ps}}$ value is 0.002 .

\subsection{TOTAL CONTAMINANT RELEASE IN A FIRE}

To estimate the total amount of contamination released during a 25 -acre range fire, the calculated plant contaminant concentrations were combined with the vegetation biomass information and fire data (Table 7). The total mass of contaminant released during a fire was calculated with the following equation:

$$
C_{T}=C_{p} \times B_{T},
$$

where

$$
B_{T}=B_{a} \times F_{m}
$$


and

$$
\begin{aligned}
& \mathrm{C}_{\mathrm{T}}=\text { total contaminant release }(\mathrm{kg}), \\
& \mathrm{C}_{\mathrm{p}}=\text { estimated plant concentration }(\mathrm{mg} / \mathrm{kg}), \\
& \mathrm{B}_{\mathrm{T}}=\text { total biomass }(\mathrm{kg}), \\
& \mathrm{B}_{\mathrm{a}}=\text { average biomass amount }(\mathrm{kg} / \mathrm{acre}), \text { and } \\
& \mathrm{F}_{\mathrm{m}}=\text { maximum size of fire }(25 \text { acres }) .
\end{aligned}
$$

As mentioned previously, a bounding-case fire was assumed to consume all of the available biomass and release all of the contaminants contained in the plant tissues. The fire was assumed to be $100 \%$ efficient, with no contamination left after the burn.

TABLE 7 Estimated Total Amounts of Contaminants of Concern Released from a 25-Acre Fire in Forest or Field Areas ${ }^{\mathrm{a}}$

\begin{tabular}{lccc}
\hline Cover Type/ & $\begin{array}{c}\text { Estimated Plant } \\
\text { Concentration }\left(\mathrm{C}_{\mathrm{P}}\right)^{\mathrm{b}} \\
(\mathrm{mg} / \mathrm{kg})\end{array}$ & $\begin{array}{c}\text { Total } \\
\text { Biomass }\left(\mathrm{B}_{\mathrm{T}}\right)^{\mathrm{c}} \\
(\mathrm{kg})\end{array}$ & $\begin{array}{c}\text { Total Contaminant } \\
\text { Amount Released }\left(\mathrm{C}_{\mathrm{T}}\right) \\
(\mathrm{kg})\end{array}$ \\
\hline Field & & & \\
Lead & $1.58 \times 10^{2}$ & $5.7 \times 10^{4}$ & 9.03 \\
Arsenic & 3.36 & $5.7 \times 10^{4}$ & 0.19 \\
DU & 0.104 & $5.7 \times 10^{4}$ & $5.93 \times 10^{-3}$ \\
TCE & 0.896 & $5.7 \times 10^{4}$ & 0.05 \\
DDT & $4.4 \times 10^{-6}$ & $5.7 \times 10^{4}$ & $2.51 \times 10^{-7}$ \\
Forest & & & \\
Lead & $1.58 \times 10^{2}$ & $1.98 \times 10^{6}$ & $3.10 \times 10^{2}$ \\
Arsenic & 3.36 & $1.98 \times 10^{6}$ & 6.62 \\
DU & 0.104 & $1.98 \times 10^{6}$ & 0.206 \\
TCE & 0.896 & $1.98 \times 10^{6}$ & 1.77 \\
DDT & $4.4 \times 10^{-6}$ & $1.98 \times 10^{6}$ & $1.13 \times 10^{-5}$ \\
\hline
\end{tabular}

a The maximum fire size, assumed to be 25 acres, was multiplied by the average biomass, in $\mathrm{kg} / \mathrm{acre}$, for J-Field and for a typical southeastern forest biomass to estimate the total biomass available $\left(\mathrm{B}_{\mathrm{T}}\right)$, in $\mathrm{kg}$, to be burned in a 25 -acre fire.

b See Table 6.

c See Table 5 . 


\section{FIREPLUME MODEL}

The computer model FIREPLUME (Brown et al. 1997) was used to estimate contaminant concentrations in smoke plumes originating from range fires. FIREPLUME is an extension of the Monte Carlo Lagrangian Dispersion Model (MCLDM) developed over the past 10 years to evaluate atmospheric dispersion of contaminants. MCLDM was originally developed to predict dispersion of military smoke (fog oil and hexachloroethane) from generators and smoke pots located near the ground; the model was later extended to include all passive releases. The evolution of the present model began with a study of dispersion under convective conditions that can arise during a fire (Liljegren 1989). Results of the Monte Carlo model developed for that application compared well with available field and laboratory data for such conditions. A particularly valuable feature of the model was its ability to match the rising centerline phenomenon that has been observed with plumes from surface releases under convective conditions (e.g., water tank data by Willis and Deardorff [1974]). Brown (1997) extended the model to treat dispersion in stable and near-neutral conditions and refined the Monte Carlo modeling in the surface layer to obtain a better estimate of ground-level concentrations.

The current version of FIREPLUME predicts ground-level concentrations resulting from releases of hazardous materials from instantaneously discharged thermals, fires, or passive releases. Releases during smoldering or cool-down phases of fires can also be included. The FIREPLUME model consists of two parts: a Monte Carlo dispersion model and a puff dispersion model. The Monte Carlo portion estimates dispersion of both buoyant and nonbuoyant releases in the atmospheric boundary layer. The puff dispersion model is a post-processor to the Monte Carlo model. The puff model uses MCLDM-generated estimates of vertical dispersion, together with standard Gaussian relationships for horizontal dispersion, to estimate the ground-level concentration for a time-dependent release rate and a specific averaging time. For time-varying releases, the puff model is required because MCLDM provides only steady-state results (Brown 1997).

\subsection{FIRE SCENARIOS}

Because of the presence of high fuel moisture, high ambient humidities, and a primarily deciduous forest canopy at APG, forest fires there are generally smaller than those that occur in western forests. As a result, these fires at APG have the potential to affect areas immediately downwind of the fire location with high concentrations of fire combustion products.

To estimate any adverse risk to APG personnel and the public from a range fire, a scenario was developed that represents a conservative, yet realistic, consequence of a fire started by lightning, artillery firing, or other accidental means. The conservative approach was selected to define the highest average concentrations for the contaminants of concern expected to occur downwind of a fire 
of realistic size in comparison with fires that have actually occurred. The conservatism built into this analysis defines a bounding case scenario and, therefore, overestimates potential impacts from any one individual fire.

The primary fire scenario is represented by a $100-\mathrm{m}$ line source of fire occurring in either 25 acres of forest or grassland. It is assumed that the APG Fire Department uses helicopter water drops to extinguish the fire within one hour of ignition, after the fire consumes the entire 25 acres. Emission rates of toxic pollutants were estimated from data for burning vegetation and from the amounts of toxins expected in plants at APG. In these fires, some smoldering of the fire remnants will occur before the Fire Department arrives and after the fire is extinguished. However, for this analysis the assumption was made that the fire completely consumes all available biomass and releases all available contaminants during this one-hour period, mobilizing the entire mass of contaminants present in the biomass burned.

The FIREPLUME model requires information on site meteorology. Because it was unclear at the outset of the study which atmospheric conditions would constitute the worst case, the following meteorological conditions were considered:

- Class A stability, representing a case with low wind speed and strong vertical mixing, typical of a clear summer afternoon with low winds;

- Class D stability, representing neutral conditions (on the slightly stable side), typical of late afternoon or early morning overcast periods with moderate winds; and

- Class E stability, representing a nighttime case with partial cloud cover and moderate winds.

It is important to note that strongly stable nighttime conditions, such as those represented by $\mathrm{F}$ stability, are not the worst case because under those conditions fire plumes rise above the atmospheric boundary layer and do not disperse back down to ground level until fumigation of the boundary layer about an hour after sunrise. Although a case of F stability was evaluated in our analysis, the results were not included in the report because resulting ground-level concentrations of contaminants were well below those predicted for the other cases.

The fire temperature assumed for both the grassland and forest cases was $175^{\circ} \mathrm{C}$. The instantaneous diameter of the line source was assumed to be $7.5 \mathrm{~m}$ and $15 \mathrm{~m}$, respectively, for the forest and grassland fires. Twenty-minute and 60-minute averages of pollutant concentrations were estimated at various downwind points from the fire. Calculated center-line values for the contaminants of concern are discussed in Section 8.2. Parameters were chosen to match likely field conditions that would result in the highest peak contaminant concentrations. The cool fire 
temperature would produce a smoke plume that would not rise as high or undergo as much dispersion as a plume from a hotter fire. The small source area would result in a more concentrated plume, yielding higher maximum calculated ground-level concentration values.

Validation of the FIREPLUME results was based on a favorable comparison of calculated values with the following observed field conditions:

- The plume rise over the immediate fire location (i.e., within a few hundred meters of the source) is between 30 and $60 \mathrm{~m}$ for most cases. This prediction qualitatively matches the average height of about $45 \mathrm{~m}$ observed by APG firefighters. Of course, the plume rises higher than $45 \mathrm{~m}$ farther downwind and at locations off the APG site.

- Residents on the eastern shore of Chesapeake Bay can smell the smoke as the plume passes by their homes. This phenomenon occurs as the plume disperses back to ground level after rising because of atmospheric turbulence. The results of the calculations (Section 8.2) indicate that for the forest fire case, Class $\mathrm{E}$ atmospheric stability provides the most rapid return of the plume to ground level (known as plume touchdown) $(\sim 750 \mathrm{~m}$ from the fire location), and that Class D stability provides the most rapid touchdown for the grassland case $(<300 \mathrm{~m})$. For all cases, significant plume material was present at ground level within $1,200 \mathrm{~m}$ of the fire location, indicating that persons farther than $1,200 \mathrm{~m}$ from the fire (including those on the eastern shore) would smell smoke.

- Plume shreds are sometimes seen $10-15 \mathrm{~km}$ downwind of the fire location during stable conditions when the fire plume rises beyond the region of strong shear-generated turbulence near the ground. The same effect can occur during the mid-to-late afternoon when a buoyant plume penetrates the inversion capping the atmospheric boundary layer, trapping material in a thin layer immediately above the inversion. This effect is not observed in the morning and early afternoon because the inversion is actively growing during this period. Because the FIREPLUME model only calculates concentrations within the atmospheric boundary layer, the model does not directly predict these phenomena. However, the model is consistent with the atmospheric boundary layer physics responsible for these effects. 


\subsection{FIREPLUME CALCULATIONS}

The different meteorological conditions for the three atmospheric stabilities (Classes A, D, and E) used for the FIREPLUME calculations produced unique plume estimates for each case, as seen in the cross-sectional diagrams shown in Figures 12-14. As shown in these figures, the assumed windspeeds were 2,5 , and $3 \mathrm{~m} / \mathrm{s}$ for Classes $\mathrm{A}, \mathrm{D}$, and $\mathrm{E}$, respectively. These figures illustrate the previously discussed rising centerline of the plumes. Each smoke plume initially rises as it moves downwind from the fire, making the ground concentrations close or equal to zero for some distance away from the fire. As the plume disperses back toward the ground because of atmospheric turbulence, the ground concentrations increase, reach a maximum at a distance $l$, and then, because of mixing and dispersion, decrease at points farther downwind.

The distance along the centerline to the point of maximum ground concentration, $l$, depends on the stability class of the fire (A, D, or E) and the fire type (forest or field). The $l$ values for various sets of conditions are listed in Table 8 . For a forest fire, the point of maximum ground concentration is $3,500 \mathrm{~m}$ downwind of the fire for stability Class A, 2,500 m for Class D, and $1,750 \mathrm{~m}$ for Class $\mathrm{E}$. For a field fire, these distances are $1,250,1,000$, and $700 \mathrm{~m}$, respectively.

As previously mentioned, the actual "plume touchdown points" occur within $1,200 \mathrm{~m}$ of the fire in forest conditions for all stability classes. The mixing height, $Z i$, is at $500 \mathrm{~m}$ for the day scenarios (A and D stability classes) and $140 \mathrm{~m}$ for the nighttime scenario (Class E). During a nighttime fire, an inversion layer, or a region of sharp temperature gradient, retards the vertical motion of the plume. At the height of this inversion layer, the plume is not completely stopped, but its upward movement is significantly hindered. The maximum plume rise directly above the fire source, $h$, is between 30 and $60 \mathrm{~m}$ for most stabilities.

TABLE 8 Point of Maximum Ground-Level Contaminant Concentration Downwind of a Fire on the Basis of FIREPLUME Modeling Results

\begin{tabular}{lccc}
\hline & \multicolumn{2}{c}{$\begin{array}{c}\text { Downwind Distance (m) of } \\
\text { Maximum Ground-Level } \\
\text { Concentration, by Stability Class }\end{array}$} \\
\cline { 2 - 4 } $\begin{array}{c}\text { Type } \\
\text { of Fire }\end{array}$ & A Stability & D Stability & E Stability \\
\hline Forest & 3,500 & 2,500 & 1,750 \\
Field & 1,250 & 1,000 & 1,250 \\
\hline
\end{tabular}


FIREPLUME concentrations were predicted from 0 to $20,000 \mathrm{~m}$ downwind of the fire. Because the predicted concentrations are time dependent, average contaminant concentrations were calculated for 20- and 60-minute intervals (20- and 60-minute moving averages). For generality, FIREPLUME calculates a normalized contaminant concentration, that is, the contaminant concentration at a point $(X, Y)$ divided by its initial concentration $(C(X=0, Y=0))$. Tabulated values of the average time-normalized concentrations are given in Appendix A.

Using the centerline concentrations ( $Y=0)$, we calculated additional concentrations at distances from 0 to $3,000 \mathrm{~m}$ perpendicular to the centerline by assuming that as the plume travels downwind, it expands laterally and maintains a Gaussian profile (Turner 1969). That is,

$$
C(X, Y)=C(X, Y=0) e^{-\left(\frac{Y}{\sqrt{2} \sigma_{X, Y}}\right)^{2}},
$$

where

$$
\begin{aligned}
& \mathrm{X}=\text { downwind distance } \\
& \mathrm{Y}=\text { perpendicular distance from the centerline, and } \\
& \sigma_{\mathrm{X}, \mathrm{Y}}=\text { standard deviation in the Gaussian plume. }
\end{aligned}
$$

Tabulated values for the plume's standard deviation as a function of $\mathrm{X}$ and $\mathrm{Y}$ are given in Appendix A. As indicated in that appendix, as the plume moves downwind, its width and, hence, standard deviation $\left(\sigma_{\mathrm{X}, \mathrm{Y}}\right)$ increase.

Because FIREPLUME calculates the normalized concentration of a contaminant in a plume, actual concentrations are obtained by multiplying this normalized concentration by the initial contaminant concentration (Table 7). The maximum ground-level concentrations predicted by FIREPLUME for the contaminants of concern along the centerline are listed in Table 9 for both the 20- and 60-minute time-averaging periods. The 20-minute values for $\mathrm{E}$ stability produced the highest predicted ground-level concentrations for both forest and field fire scenarios. The calculations indicate that a forest fire would produce higher concentrations than a field fire for all of the contaminants.

Figures 15 illustrates an aerial view of predicted ground concentrations of the smoke plumes on a map of APG. Figure 15 represents a Class E stability forest fire on the Aberdeen Area between the Main Front Area and Trench Warfare ranges, where approximately 20\% of the reported fires occurred. The figure shows the 20-minute averaged ground-level concentrations for arsenic in the fire plume. The plume's direction coincides with prevailing APG winds that transport the 
TABLE 9 Maximum Contaminant Concentrations $\left(\mathrm{mg} / \mathrm{m}^{3}\right)$ at Ground Level for A, D, and E Atmospheric Stability Classes in Forest and Field Fires as Predicted by the FIREPLUME Dispersion Model $^{\mathbf{a}}$

\begin{tabular}{|c|c|c|c|c|c|c|c|}
\hline \multirow[b]{2}{*}{ Contaminant } & \multirow{2}{*}{$\begin{array}{c}\text { Time } \\
\text { Average } \\
\text { (min) }\end{array}$} & \multicolumn{3}{|c|}{ Forest Fire Scenarios } & \multicolumn{3}{|c|}{ Field Fire Scenarios } \\
\hline & & A Stability & D Stability & E Stability & A Stability & D Stability & E Stability \\
\hline \multirow[t]{2}{*}{ Lead } & 20 & $5.08 \times 10^{-2}$ & $4.65 \times 10^{-2}$ & $9.70 \times 10^{-2}$ & $2.40 \times 10^{-3}$ & $4.94 \times 10^{-3}$ & $1.55 \times 10^{-2}$ \\
\hline & 60 & $4.77 \times 10^{-2}$ & $4.62 \times 10^{-2}$ & $9.62 \times 10^{-2}$ & $2.33 \times 10^{-3}$ & $4.92 \times 10^{-3}$ & $1.55 \times 10^{-2}$ \\
\hline \multirow[t]{2}{*}{ Arsenic } & 20 & $1.09 \times 10^{-3}$ & $9.93 \times 10^{-4}$ & $2.07 \times 10^{-3}$ & $5.05 \times 10^{-5}$ & $1.04 \times 10^{-4}$ & $3.44 \times 10^{-4}$ \\
\hline & 60 & $1.02 \times 10^{-3}$ & $9.86 \times 10^{-4}$ & $2.05 \times 10^{-3}$ & $4.90 \times 10^{-5}$ & $1.04 \times 10^{-4}$ & $3.42 \times 10^{-4}$ \\
\hline \multirow[t]{2}{*}{ DU } & 20 & $3.44 \times 10^{-5}$ & $3.15 \times 10^{-5}$ & $6.58 \times 10^{-5}$ & $1.60 \times 10^{-6}$ & $3.28 \times 10^{-6}$ & $1.08 \times 10^{-5}$ \\
\hline & 60 & $3.23 \times 10^{-5}$ & $3.13 \times 10^{-5}$ & $6.51 \times 10^{-5}$ & $1.55 \times 10^{-6}$ & $3.27 \times 10^{-6}$ & $1.08 \times 10^{-5}$ \\
\hline \multirow[t]{2}{*}{ TCE } & 20 & $2.90 \times 10^{-4}$ & $2.66 \times 10^{-4}$ & $5.54 \times 10^{-4}$ & $1.33 \times 10^{-5}$ & $2.74 \times 10^{-5}$ & $9.06 \times 10^{-5}$ \\
\hline & 60 & $2.73 \times 10^{-4}$ & $2.64 \times 10^{-4}$ & $5.49 \times 10^{-4}$ & $1.29 \times 10^{-5}$ & $2.72 \times 10^{-5}$ & $9.00 \times 10^{-5}$ \\
\hline \multirow[t]{2}{*}{ DDT } & 20 & $2.00 \times 10^{-9}$ & $2.00 \times 10^{-9}$ & $3.54 \times 10^{-9}$ & $6.68 \times 10^{-11}$ & $1.37 \times 10^{-10}$ & $4.55 \times 10^{-10}$ \\
\hline & 60 & $2.00 \times 10^{-9}$ & $2.00 \times 10^{-9}$ & $3.51 \times 10^{-9}$ & $6.48 \times 10^{-11}$ & $1.37 \times 10^{-10}$ & $4.52 \times 10^{-10}$ \\
\hline \multirow[t]{2}{*}{ 2-Furaldehyde } & 20 & 1.33 & 1.21 & 2.51 & $7.77 \times 10^{-2}$ & $1.60 \times 10^{-1}$ & $5.29 \times 10^{-1}$ \\
\hline & 60 & 1.24 & 1.20 & 2.48 & $7.56 \times 10^{-2}$ & $1.59 \times 10^{-1}$ & $5.26 \times 10^{-1}$ \\
\hline \multirow[t]{2}{*}{ Vinyl acetate } & 20 & 4.85 & 4.44 & 9.27 & $3.80 \times 10^{-2}$ & $7.82 \times 10^{-2}$ & $2.59 \times 10^{-1}$ \\
\hline & 60 & 4.55 & 4.41 & 9.18 & $3.69 \times 10^{-2}$ & $7.79 \times 10^{-2}$ & $2.57 \times 10^{-1}$ \\
\hline
\end{tabular}

a See Table 8 for the distance downwind of the fire associated with each of the stabilities.

plumes to the southeast. The change of color (from black to gray) represents the decreasing contaminant concentration downwind from the source.

\subsection{SOIL DEPOSITION FROM PLUME-BORNE CONTAMINANTS}

Upon contact with the ground, contaminants in the smoke plume are deposited on the soil. A rate of deposition is required to calculate the resulting soil concentrations. For this study, a conservative (high) deposition rate of $5 \mathrm{~cm} / \mathrm{s}$ was used for smoke particles ranging between 1 and $5 \mu \mathrm{m}$ in size (Brown 1997). Because deposition was assumed to occur over a period of one hour (the same as the duration of the fire) at the maximum concentration rate, the projected deposited concentrations are expected to be conservative. Once deposited, the contaminants were then assumed 
to $\mathrm{mix}$ with the top $1 \mathrm{~cm}$ of the soil to produce a final soil concentration. This process can be represented by the following equation:

$$
D=\frac{M R \times D R \times 3600 s}{S D}
$$

where

$$
\begin{aligned}
& D=\text { deposition }(\mathrm{ppm}[\mathrm{g} \text { contaminant } / \mathrm{kg} \text { soil }]) \\
& M R=\text { maximum contaminant release concentration }\left(\mathrm{g} / \mathrm{cm}^{3}\right) \\
& D R=\text { deposition rate }(5 \mathrm{~cm} / \mathrm{s}), \text { and } \\
& S D=\text { soil density }\left(1.8 \mathrm{~g} / \mathrm{cm}^{3}\right)
\end{aligned}
$$

The maximum soil values for each contaminant calculated with Equation 7 are given in Table 10 . Table 10 also details the suggested action levels for each of these contaminants. As shown by the table, soil contamination that results from deposition is well below any of the action levels. Because of these low values, exposure pathways other than inhalation were not considered.

TABLE 10 Maximum Predicted Contaminant

Concentrations in Soil from Deposition and Corresponding Action Levels

\begin{tabular}{lcc}
\hline & $\begin{array}{c}\text { Maximum } \\
\text { Estimated Soil } \\
\text { Concentration } \\
\text { from Deposition } \\
(\mathrm{mg} / \mathrm{kg})\end{array}$ & $\begin{array}{c}\text { Suggested Soil } \\
\text { Contamination } \\
\text { Action Levels } \\
(\mathrm{mg} / \mathrm{kg})\end{array}$ \\
\hline Lead & & \\
Arsenic & $9.70 \times 10^{-4}$ & 400 \\
DU & $2.10 \times 10^{-5}$ & 380 \\
TCE & $6.58 \times 10^{-7}$ & Not given \\
DDT & $6.00 \times 10^{-6}$ & 58 \\
2-Furaldehyde & $3.51 \times 10^{-11}$ & 1.9 \\
Vinyl acetate & $5.29 \times 10^{-3}$ & Not given \\
\hline
\end{tabular}

a Sources: EPA (1994a, 1995c). 


\section{UXO RELEASE SCENARIOS}

The UXO release scenario for this study matches as closely as possible the actual range fire modeling scenario. For this scenario, a round of UXO is assumed to "cook-off" during a range fire, releasing chemical warfare agent. This agent is carried up with the rising plume from the range fire and reaches some maximum concentration level downwind of the fire. This scenario results in lower concentrations than would result if the UXO round was detonated without a fire present, because the rising plume from the fire would carry the agent aloft and mix and disperse it before it came in contact with the ground. As described in Section 4.3, the maximum credible release from one UXO round is $12.72 \mathrm{~kg}$ of phosgene from a Livens projectile and $2.72 \mathrm{~kg}$ of mustard from a 4.2 -in. mortar.

The release of agent from the selected rounds in an event assumed to occur once a year was modeled with both the FIREPLUME and the D2PC codes. FIREPLUME predicted maximum release concentrations of $4.6 \times 10^{-3} \mathrm{mg} / \mathrm{m}^{3}$ and $2.2 \times 10^{-2} \mathrm{mg} / \mathrm{m}^{3}$ for mustard gas and phosgene, respectively. The corresponding concentrations predicted by D2PC were $3.4 \times 10^{-3} \mathrm{mg} / \mathrm{m}^{3}$ for mustard and $1.6 \times 10^{-2} \mathrm{mg} / \mathrm{m}^{3}$ for phosgene.

\subsection{D2PC MODEL}

A review of nuclear, biological, and chemical agent (NBC) models in 1996 by DOD recommended that $\mathrm{D} 2 \mathrm{PC}$ be used in modeling accidental chemical agent releases from chemical agent depots (Gibbs and Miller 1996). This model has been used by the Army for the past 10 years in various forms, starting with the earlier-developed D2 model.

D2PC predicts the dispersion of chemical agents for accident scenarios involving a variety of munitions, agents, and meteorological conditions. The model predicts a straight-line plume in each case on the basis of Gaussian dispersion theory. A recently developed puff version of the model allows each puff from the release to be sent downwind as the wind changes with time. The older D2PC cigar-shaped plume has been used to make predictions for this fire case because timedependent wind information is used here. A bounding case analysis is needed to evaluate the impacts if a phosgene- or mustard-containing round releases its contents during a range fire. The D2PC model predicts the impacts of a UXO agent in a fire and its downwind consequences. The model is menu-driven and requests information on the site, weather, munition, agent, and type of release, including explosion. Predictions can be made in terms of concentration or dosage contours.

The D2PC model uses a different approach than that used in FIREPLUME (Section 8.2). FIREPLUME uses modern boundary-layer meteorological methods, while the D2PC model uses the traditional Pasquill-Gifford stability class approach. The FIREPLUME model has an infinite number of meteorological conditions that could be represented; the D2PC has a finite number of 
meteorological conditions because of the classification of atmospheric conditions into A-F stability classes.

\subsection{D2PC CALCULATIONS}

The D2PC model was run for both the phosgene and mustard UXO cases. In the release scenarios, an explosion of the UXO (caused by heat from the range fire) leads to the release of the agent. The agent was treated as a tracer in the dispersion analysis. The fire option was used in the D2PC model. Reasonable assumptions as to fire diameter and caloric heat rate $(\mathrm{cal} / \mathrm{s})$ of the fire were required; the model used those inputs to predict plume rise and downwind dispersion of the agent. The presence of the fire led to buoyant rise of the plume, which helped reduce impacts at ground level. The plume rise predicted by D2PC was similar to the rise predicted by the FIREPLUME runs for toxic chemical releases. This similarity would be expected because the fire provides the predominant buoyancy in both toxic chemical and UXO release cases. Predictions were averaged over one hour to match the duration of the fires assumed for this study (Jones 1997).

The D2PC model provided results in both the $\mathrm{D}$ and $\mathrm{E}$ stability cases, which were also used in the FIREPLUME runs. D2PC could not make predictions for the A stability case; however, impacts for that case would be low because of the strong mixing that occurs during such atmospheric conditions. In the D2PC runs, the D and E stability cases led to maximum concentrations that were slightly lower than those predicted by FIREPLUME. D2PC was expected to be more conservative than FIREPLUME since D2PC's modeling methodology is less complex and D2PC was developed to provide conservative estimates of plume predictions. In this use, however, D2PC appears to yield results very similar to those of FIREPLUME, although slightly less conservative.

\subsection{UXO RELEASE RESULTS}

The results from the FIREPLUME model and the D2PC model agree to within $40 \%$, with FIREPLUME predicting higher concentrations for both mustard and phosgene $\left(4.6 \times 10^{-3} \mathrm{mg} / \mathrm{m}^{3}\right.$ and $2.2 \times 10^{-2} \mathrm{mg} / \mathrm{m}^{3}$, respectively, compared with D2PC results of $3.4 \times 10^{-3} \mathrm{mg} / \mathrm{m}^{3}$ for mustard and $1.6 \times 10^{-2} \mathrm{mg} / \mathrm{m}^{3}$ for phosgene). For the purposes of this study, we feel that FIREPLUME does a better job of modeling the convective transport of the agents due to the fire. D2PC was not designed to address these types of scenarios, although, as the results show, it does predict values close to those we feel are correct. The calculated UXO concentrations are compared with screening levels in Section 10.2. 


\section{RISK ANALYSIS}

Because this study is a preliminary assessment of possible risks to human health resulting from range fires at APG, risk assessments were performed only for the inhalation exposure pathway. That pathway provides the most direct impact to an exposed receptor, and calculating the risk for that exposure pathway provides an indication of the significance of other potential pathways that could be included in future studies. Other pathways, such as ingestion, are deemed to present low risk because of the low estimated soil contamination that would result from the fires.

Risk assessment calculations typically evaluate carcinogenic (cancer) and noncarcinogenic (noncancerous) risks in terms of risk factors and hazard indices, respectively. In evaluating impacts at a National Priority List (NPL) site, the EPA (1990) has established an acceptable risk range of $1 \times 10^{-4}$ to $1 \times 10^{-6}$ (i.e., one in 10,000 to one in $1,000,000$ ); acceptable hazard indices have values less than 1.0. Rather than calculating the actual risk values and hazard indices associated with the contaminants of concern, for this study we calculated screening action levels. These values, as discussed in Section 10.1, represent the maximum airborne contaminant concentrations for single contaminants that would result in acceptable risk values and hazard indices. Concentrations less than the screening action level are considered to present negligible risk of human health impacts. However, the screening action levels address toxicity for individual contaminants only. Calculation of the potential (if any) for additive or synergistic effects from exposures to multiple contaminants is considered beyond the scope of this study.

\subsection{SCREENING ACTION LEVELS FOR CHEMICAL CONTAMINANTS IN AIR}

The screening action levels for air concentrations of the contaminants of concern were calculated by using exposure assumptions specific to the APG range-fire scenarios. When uncertainties in exposure and/or toxicity existed, the methods and assumptions used in calculating the screening action levels were designed to ensure that the potential for adverse health impacts would not be underestimated.

The screening action levels for noncarcinogenic chemical contaminants in air were calculated as threshold-level concentrations below which adverse human health effects would be unlikely. For chemicals known or suspected of causing cancer in humans, a range of screening action level concentrations was developed corresponding to increased lifetime cancer risks of between 1 in 10,000 and 1 in 1,000,000 (EPA 1990). The modeled air concentrations at the exposure location of the human receptor being evaluated were compared with screening action level concentrations to determine if adverse health impacts might be expected. 
For purpose of these calculations, it was assumed that the reasonable maximum exposure would occur to an individual located at the point of highest ground-level concentration. The worstcase scenario modeled was for a fire destroying 25 acres of vegetation.

The actual receptors inhaling contaminants from APG range fires would be different for each fire, depending on the fire location and size, the wind direction, and other meteorological conditions at the time of the fire. However, for exposure to most of the contaminants, it was assumed that the same receptor would be located at the point of highest ground-level contamination for each of the five annual 25-acre fires modeled for this study. It was further assumed that this exposure rate (five times per year) would continue for 12 years for a child and 30 years for an adult. (These durations are explained in detail below.) Therefore, in the calculation of screening action levels, the receptor was assumed to be exposed to emissions from five 25 -acre fires annually, with each exposure lasting one hour (the average duration of fires [Jones 1997]), for an exposure duration of either 12 or 30 years. For exposure to UXO contaminants (mustard and phosgene), it was assumed that the receptor would be exposed to emissions from one 25 -acre fire annually.

In the evaluation of fire impacts, the characteristics of the human receptor may be of significance, depending on the potential exposure location. For example, if fire impacts were evaluated for a restricted on-site area, it would be most appropriate to evaluate an adult worker. However, if the potential exposure location were a residential area, it would be more protective to evaluate potential exposures of children, who can be more sensitive to the effects of toxic substances because of differences in size, metabolism, and exposure potential. Therefore, screening action levels for most contaminants of concern were calculated for both adults and children. For noncarcinogens, the differences between adult and child screening action levels are large; calculated screening action levels for children are about half of those for adults. For carcinogens, screening action levels for children are slightly higher than those for adults, mainly because of differences in EPArecommended assumptions on the averaging time.

The basic equation used to calculate screening action levels for most of the contaminants of concern is based on EPA (1991b) guidance for calculating preliminary remediation goals. The equation is given as:

$$
\text { Screening Action Level }=\frac{(R f D \text { or } R / S F) \times B W \times A T}{I \times A \times E D},
$$

where

$$
\begin{aligned}
\mathrm{RfD}= & \text { inhalation reference dose }(\mathrm{mg} / \mathrm{kg} \cdot \mathrm{d}) ; \text { used for noncarcinogens; } \\
& \text { calculated from reference concentration }\left(\mathrm{mg} / \mathrm{m}^{3}\right) \text { as: } \\
& \left(\mathrm{RfC} \times 20 \mathrm{~m}^{3} / \mathrm{d}\right) / 70 \mathrm{~kg}
\end{aligned}
$$


$\mathrm{R}=$ acceptable risk level for carcinogens: range of $10^{-6}$ to $10^{-4}$

$\mathrm{SF}=$ slope factor $(\mathrm{mg} / \mathrm{kg} \cdot \mathrm{d})^{-1}$, used for carcinogens;

$\mathrm{BW}=$ body weight: $70 \mathrm{~kg}$ for adult, $24 \mathrm{~kg}$ average for child age 0-12 $\mathrm{yr}$ (recommended values from EPA 1995a);

$\mathrm{AT}=$ averaging time: $30 \mathrm{yr} \times 365 \mathrm{~d} / \mathrm{yr}$ (noncarcinogens-adult); $12 \mathrm{yr} \times$ $365 \mathrm{~d} / \mathrm{yr}$ (noncarcinogens-child); $70 \mathrm{yr} \times 365 \mathrm{~d} / \mathrm{yr}$ (carcinogens-adult or child);

$I$ = inhalation rate: $1.7 \mathrm{~m}^{3} / \mathrm{h}$ for adult, $1.2 \mathrm{~m}^{3} / \mathrm{h}$ for child (recommended values for individuals at moderate activity levels, EPA 1995a);

$\mathrm{A}=$ absorption factor: default of 1 ; and

$\mathrm{ED}=$ exposure duration: $1 \mathrm{~h} / \mathrm{d} \times 5 \mathrm{~d} / \mathrm{yr} \times 30 \mathrm{yr}$ (adult); $1 \mathrm{~h} / \mathrm{d} \times 5 \mathrm{~d} / \mathrm{yr} \times 12 \mathrm{yr}$ (child) (for UXO contaminants, $1 \mathrm{~d} / \mathrm{yr}$ was used).

Exposure assumptions were based on guidance available from EPA documents (EPA 1989, 1991a, 1995a).

Reference concentrations or slope factors for most of the contaminants of concern (Section 4) are available from the EPA (1995b, 1996, 1997) (as listed in Table 11). Exceptions include lead, mustard, phosgene, and uranium. The methods used to calculate screening action levels for these exception substances are discussed below. Screening action levels for all of the contaminants of concern are given in Table 12 .

\subsubsection{Lead}

Lead is ubiquitous in the environment, found at varying levels in water, soil, food, household products such as paint and some older cooking utensils, and in the air. Because lead absorption can occur from exposure to any of these sources, the EPA has developed a model to account for expected background exposures to lead when evaluating any new potential source of lead exposure (EPA 1994b). This model estimates lead concentrations in blood associated with varying exposure levels for children up to 7 years old, the most sensitive potentially exposed population. For our analysis, the EPA model was run with default assumptions on intake of lead from water, soil, food, and other sources. The assumed inhalation rate was set to $1.2 \mathrm{~m}^{3} / \mathrm{h}$, a rate consistent with moderate activity levels in children (EPA 1995a). 
TABLE 11 Inhalation Toxicity Values for Contaminants of Concern

\begin{tabular}{|c|c|c|c|c|c|c|}
\hline Substance $^{\mathrm{a}}$ & $\begin{array}{c}\text { CAS } \\
\text { Number }\end{array}$ & $\begin{array}{c}\text { Chronic } \\
\text { Inhalation } \\
\operatorname{RfC}\left(\mathrm{mg} / \mathrm{m}^{3}\right)\end{array}$ & $\begin{array}{c}\text { Inhalation } \\
\text { RfD } \\
(\mathrm{mg} / \mathrm{kg} \cdot \mathrm{d})\end{array}$ & $\begin{array}{l}\text { Inhalation } \\
\text { Unit Risk } \\
\left(\mu \mathrm{g} / \mathrm{m}^{3}\right)^{-1}\end{array}$ & $\begin{array}{l}\text { Inhalation } \\
\text { Slope Factor } \\
(\mathrm{mg} / \mathrm{kg} \cdot \mathrm{d})^{-1}\end{array}$ & $\begin{array}{c}\text { Carcinogen } \\
\text { Group }\end{array}$ \\
\hline Lead & $7439-92-1$ & $N A^{c}$ & NA & $\mathrm{NA}$ & NA & NA \\
\hline Arsenic & $7440-38-2$ & NA & $\mathrm{NA}$ & $4.3 \times 10^{-3}$ & 15.05 & $\mathrm{~A}$ \\
\hline Uranium (DU) & NA & NA & $3 \times 10^{-4}$ & NA & NA & NA \\
\hline TCE & $79-01-6$ & NA & NA & $\mathrm{NA}$ & $6 \times 10^{-3}$ & $\mathrm{~B}-\mathrm{C}$ \\
\hline DDT & $50-29-3$ & NA & NA & $9.7 \times 10-5$ & $3.4 \times 10^{-1}$ & $\mathrm{~B} 2$ \\
\hline 2-Furaldehyde ${ }^{d}$ & 98-01-1 & $5 \times 10^{-2}$ & $1.4 \times 10^{-2}$ & NA & NA & NA \\
\hline Vinyl acetate & $108-05-4$ & $2 \times 10^{-1}$ & $5.7 \times 10^{-2}$ & $\mathrm{NA}$ & NA & NA \\
\hline Mustard gas & $505-60-2$ & NA & NA & NA & $300^{e}$ & 1 \\
\hline Phosgene $e^{f}$ & $75-44-5$ & NA & NA & $\mathrm{NA}$ & NA & NA \\
\hline
\end{tabular}

a Toxicity data for arsenic, DDT, and vinyl acetate obtained from EPA (1997); toxicity data for TCE from EPA (1996); toxicity data for 2-furaldehyde from EPA (1995b). Toxicity data for uranium based on adjusted permissible exposure level (29 CFR 1910), see text.

b Carcinogen groups: Group A - human carcinogen; Group B - probable human carcinogen; Group C possible human carcinogen; Group 1 - known carcinogen.

c NA = not applicable.

d 2-Furaldehyde also known as furfural.

e Slope factor for mustard taken from EPA (1991c).

$f$ Phosgene is a direct-acting toxin of the lower respiratory tract that causes pulmonary edema; available data are insufficient to calculate an RfC.

The current recommended limit for blood lead levels in children is $10 \mu \mathrm{g} / \mathrm{dL}$. A screening action level for lead of $1.5 \mathrm{mg} / \mathrm{m}^{3}$ was calculated as the air concentration that would result in blood lead levels of less than $10 \mu \mathrm{g} / \mathrm{dL}$ for $90 \%$ or more of the exposed population. This value produced calculated mean blood lead levels for children aged 0 to 7 years that ranged from 3.8 to $6.0 \mu \mathrm{g} / \mathrm{dL}$. The actual air concentration input into the model was $1 \mu \mathrm{g} / \mathrm{m}^{3}$; this value was multiplied by the factor of $[(24 \mathrm{~h} / \mathrm{d} \times 365 \mathrm{~d} / \mathrm{yr}) / 5 \mathrm{~h} / \mathrm{yr}]$, to adjust the exposure duration assumed in the model to a value appropriate for modeling exposures from APG range fires.

No separate screening action level was calculated to evaluate adult exposures to lead. The EPA model is not applicable for adult exposures, and other methods for calculating potential health impacts from adult exposures were not located. Because adults do not absorb lead as efficiently as children and because some of the adverse developmental effects of concern for children would not be applicable to adults, the screening action level calculated for children would certainly also be protective for adults. In the absence of further quantitative evaluation tools for adult lead exposures 
TABLE 12 Screening Action Levels for Contaminants in Air

\begin{tabular}{|c|c|c|c|c|c|c|}
\hline \multirow[b]{3}{*}{ Substance } & \multirow{2}{*}{\multicolumn{2}{|c|}{$\begin{array}{l}\text { Noncarcinogen } \\
\text { Screening Action } \\
\text { Level }\left(\mathrm{mg} / \mathrm{m}^{3}\right)\end{array}$}} & \multicolumn{4}{|c|}{ Carcinogen Screening Action Level $\left(\mathrm{mg} / \mathrm{m}^{3}\right)$} \\
\hline & & & \multicolumn{2}{|c|}{ Child } & \multicolumn{2}{|c|}{ Adult } \\
\hline & Child & Adult & Low End & High End & Low End & High End \\
\hline Lead $^{\mathrm{a}}$ & 1.5 & $\mathrm{NA}^{\mathrm{b}}$ & NA & NA & NA & NA \\
\hline Arsenic & NA & $\mathrm{NA}$ & $5.7 \times 10^{-4}$ & $5.7 \times 10^{-2}$ & $4.7 \times 10^{-4}$ & $4.7 \times 10^{-2}$ \\
\hline Uranium (DU) & 0.44 & 0.9 & NA & NA & NA & NA \\
\hline TCE & NA & NA & 14 & $1.40 \times 10^{2}$ & 1.2 & $1.20 \times 10^{2}$ \\
\hline DDT & NA & NA & $2.5 \times 10^{-2}$ & 2.5 & $2.1 \times 10^{-2}$ & 2.1 \\
\hline 2-Furaldehyde & 21 & 43 & NA & NA & NA & NA \\
\hline Vinyl acetate & 83 & $1.70 \times 10^{2}$ & NA & NA & NA & $\mathrm{NA}$ \\
\hline Mustard gas ${ }^{c}$ & $1 \times 10^{-4}$ & $1 \times 10^{-4}$ & $1.4 \times 10^{-4}$ & $1.4 \times 10^{-2}$ & $1.2 \times 10^{-4}$ & $1.2 \times 10^{-2}$ \\
\hline Phosgene $^{\mathrm{d}}$ & 0.2 & 0.2 & NA & NA & NA & NA \\
\hline
\end{tabular}

a Screening action level for lead calculated from EPA (1994b).

b $\mathrm{NA}=$ not applicable.

c Mustard is a direct-acting blister agent. The noncarcinogen action level given is a control limit for general public exposures of up to 72 hours; it is not a risk estimate, but rather the lowest detectable level (Centers for Disease Control 1988).

d Phosgene concentration given is the minimum level associated with beginning lung damage for a 1-hour exposure, divided by an uncertainty factor of 10 to account for sensitive subpopulations.

and because of the screening nature of this study, the screening action level for children was applied to adult exposure scenarios.

\subsubsection{Mustard}

Mustard is a chemical warfare agent with the principal effects of blistering of the skin and damaging the eyes, even at relatively low concentrations in air. Mustard is a direct acting agent (i.e., it causes damage directly at the point of contact). Mustard is also categorized as a known carcinogen (ATSDR 1992b). Evidence of carcinogenicity is from (1) increased cancer incidence among factory workers who made mustard gas and other chemical agents; (2) a slight, but statistically significant, increased incidence of lung cancer deaths among World War I veterans exposed in combat (these studies did not control for cigarette smoking); and (3) two animal studies showing increased incidence of pulmonary tumors (ATSDR 1992b). None of these studies was sufficiently extensive to establish a dose/response relationship for mustard-induced cancers. 
Although mustard is considered to be a carcinogen, the available data have generally been considered inadequate to estimate the carcinogenic potency (i.e., carcinogenic risk) of mustard (CDC 1988; ATSDR 1992b). Neither is information on mustard toxicity and carcinogenicity available through EPA's IRIS and HEAST databases. Nonetheless, because of a need to estimate potential risks to populations residing near military sulfur mustard stockpile locations, the EPA did use the available (and inadequate) data to estimate a carcinogenic potency of $300(\mathrm{mg} / \mathrm{kg} \cdot \mathrm{d})^{-1}$ for mustard (EPA 1991c). The accuracy of risks estimates generated using this value must be considered highly uncertain.

No reference dose for evaluating potential noncarcinogenic effects is available for mustard through EPA's IRIS or HEAST databases. The Centers for Disease Control (CDC) evaluated the available toxicity data for mustard and established a control limit of $0.0001 \mathrm{mg} / \mathrm{m}^{3}$ for general population exposures of up to 72 hours (CDC 1988). The control limit is not a risk-based value; rather, it is the lowest detectable level of mustard in air. The control limit can be compared with the lowest level observed to cause adverse noncarcinogenic effects. A recent work summarizing the extensive human and animal acute exposure data reports that the maximum safe exposure level that would not result in damage to the eyes or skin would be $50 \mathrm{mg} \mathrm{min} / \mathrm{m}^{3}$ (Marrs et al. 1996). This value corresponds to a concentration of $0.83 \mathrm{mg} / \mathrm{m}^{3}$ for a 1 -hour exposure duration. Therefore, the control limit established by CDC has a safety margin against acute effects of about 8,000 $(0.830 / .0001)$ for a 1-hour exposure period.

\subsubsection{Phosgene}

Phosgene is a chemical warfare agent whose principal toxicologic effect is causing pulmonary edema (abnormal accumulation of fluid in the lungs). High exposure levels (e.g., levels greater than about $800 \mathrm{mg} / \mathrm{m}^{3}$ ) cause almost immediate death. At lower exposure levels (between 100 and $800 \mathrm{mg} / \mathrm{m}^{3}$ ), immediate symptoms include irritation of the eyes and throat, pain or tightness of the chest, coughing, and shortness of breath. These symptoms generally end within 5 or 10 minutes of exposure and are followed by a "latent" phase lasting 1 to 24 hours, during which no symptoms are apparent. The latent phase ends when pulmonary edema becomes sufficient to interfere with respiration; symptoms include shortness of breath and a productive (often bloody) cough. Without immediate medical attention, death may occur because of a lack of sufficient circulation and oxygen throughout the body. If the patient recovers from the edema, antibiotic therapy is needed to ensure that pneumonia does not occur. Similar to mustard gas, phosgene is a direct-acting toxin in the lower airway passages of the lungs; it does not get past the pulmonary circulation. The EPA has concluded that data on toxic effects of chronic low-level phosgene exposures are insufficient to calculate a reference concentration or dose.

Although no reference dose has been calculated for phosgene, researchers have concluded that no significant human health effects have been found at phosgene air concentrations below 
$0.1 \mathrm{ppm}$ (EPA 1986). This "no-effect" level is fairly consistent with a calculated level based on a report of the minimum concentration of $30 \mathrm{ppm}$-min associated with beginning lung damage (EPA 1986). This level corresponds to a concentration of $0.5 \mathrm{ppm}\left(2 \mathrm{mg} / \mathrm{m}^{3}\right)$ for a 1-hour exposure. The air screening action level of $0.2 \mathrm{mg} / \mathrm{m}^{3}$ cited in Section 10.2 (Table 13) also incorporates an uncertainty factor of 10 to account for possible sensitive subpopulations.

\subsubsection{Depleted Uranium}

No inhalation reference concentration is currently available for uranium from standard EPA sources. To assess the potential risk from inhalation of uranium and its compounds, an interim reference concentration was developed from the proposed U.S. Department of Labor permissible exposure level (PEL) for uranium (29 CFR Part 1910, Subpart Z, 1991). The proposed 8-hour timeweighted-average PEL for soluble uranium compounds is $0.05 \mathrm{mg} / \mathrm{m}^{3}$. This value was converted to an assumed inhalation reference dose value (in $\mathrm{mg} / \mathrm{kg} \cdot \mathrm{d}$ ) for an adult worker on the basis of an inhalation rate of $9.6 \mathrm{~m}^{3} /$ workday and a body weight of $70 \mathrm{~kg}$, which resulted in an interim worker inhalation reference dose of $0.014 \mathrm{mg} / \mathrm{kg} \cdot \mathrm{d}$. To generate an interim inhalation reference dose for the general public, the worker value was adjusted to account for increased exposure duration of the general public (assumed 168 hours exposure per week instead of 40 hours per week); an additional uncertainty factor of 10 was used to account for sensitive subpopulations in the general public. These assumptions and factors resulted in an interim inhalation reference dose value for uranium for the general public of $3 \times 10^{-4} \mathrm{mg} / \mathrm{kg} \cdot \mathrm{d}$, as shown in Table 11 .

\subsection{COMPARISON OF CALCULATED PLUME VALUES WITH SCREENING LEVELS}

\subsubsection{Inhalation Pathway}

Table 13 summarizes the results of the comparison of calculated exposure levels for a "most exposed individual" with the screening action levels developed for this study. This table is divided into two sections; the first section compares the results calculated for a field fire with the screening action levels, and the second section compares the results calculated for a forest fire. Comparisons are included for both carcinogenic and noncarcinogenic risk and action levels for both children and adults, as appropriate.

Calculated exposure values for lead are about 100 times lower than the screening action level for a child. There is no screening action level for adults. 
TABLE 13 Maximum Contaminant Release Concentrations as Predicted by FIREPLUME Compared with Action Levels

\begin{tabular}{|c|c|c|c|c|c|}
\hline \multirow{3}{*}{$\begin{array}{l}\text { Fire Type/ } \\
\text { Contaminant }\end{array}$} & \multirow{3}{*}{$\begin{array}{l}\text { Maximum } \\
\text { Release } \\
\text { Concentration }{ }^{\mathrm{a}} \\
\left(\mathrm{mg} / \mathrm{m}^{3}\right)\end{array}$} & \multirow{2}{*}{\multicolumn{2}{|c|}{$\begin{array}{c}\text { Noncarcinogen Air } \\
\text { Screening Action } \\
\text { Level } \\
\left(\mathrm{mg} / \mathrm{m}^{3}\right)\end{array}$}} & \multicolumn{2}{|c|}{$\begin{array}{c}\text { Carcinogen Air Screening } \\
\text { Action Level }\left(\mathrm{mg} / \mathrm{m}^{3}\right)\end{array}$} \\
\hline & & & & \multirow{2}{*}{$\begin{array}{l}\text { Child, } \\
\text { Low to High } \\
\text { End }\end{array}$} & \multirow{2}{*}{$\begin{array}{l}\text { Adult, } \\
\text { Low to High } \\
\text { End }\end{array}$} \\
\hline & & Child & Adult & & \\
\hline \multicolumn{6}{|l|}{ Field Fire } \\
\hline Lead & $1.6 \times 10^{-2}$ & 1.5 & $N A^{b}$ & NA & NA \\
\hline Arsenic & $3.44 \times 10^{-4}$ & NA & NA & $\begin{array}{l}5.7 \times 10^{-4} \text { to } \\
5.7 \times 10^{-2}\end{array}$ & $\begin{array}{l}4.7 \times 10^{-4} \text { to } \\
4.7 \times 10^{-2}\end{array}$ \\
\hline Uranium (DU) & $6.58 \times 10^{-5}$ & 0.44 & 0.9 & & \\
\hline TCE & $9.06 \times 10^{-5}$ & NA & $\mathrm{NA}$ & 1.4 to 140 & 1.2 to 120 \\
\hline DDT & $4.55 \times 10^{-10}$ & NA & NA & $\begin{array}{l}2.5 \times 10^{-2} \text { to } \\
2.5\end{array}$ & $\begin{array}{l}2.1 \times 10^{-2} \text { to } \\
2.1\end{array}$ \\
\hline 2 Furaldehyde & $5.29 \times 10^{-1}$ & 21 & 43 & NA & NA \\
\hline Vinyl acetate & $2.59 \times 10^{-1}$ & 83 & 170 & NA & NA \\
\hline \multicolumn{6}{|l|}{ Forest Fire } \\
\hline Lead & $9.70 \times 10^{-2}$ & 1.5 & NA & NA & NA \\
\hline Arsenic & $2.07 \times 10^{-3}$ & NA & NA & $\begin{array}{l}5.7 \times 10^{-4} \text { to } \\
5.7 \times 10^{-2}\end{array}$ & $\begin{array}{l}4.7 \times 10^{-4} \text { to } \\
4.7 \times 10^{-2}\end{array}$ \\
\hline Uranium (DU) & $6.58 \times 10^{-5}$ & 0.44 & 0.9 & NA & NA \\
\hline TCE & $5.54 \times 10^{-4}$ & $\mathrm{NA}$ & NA & 1.4 to 140 & 1.2 to 120 \\
\hline $\mathrm{DDT}$ & $3.54 \times 10^{-9}$ & NA & NA & $\begin{array}{l}2.5 \times 10^{-2} \text { to } \\
2.5\end{array}$ & $\begin{array}{l}2.1 \times 10^{-2} \text { to } \\
2.1\end{array}$ \\
\hline 2 Furaldehyde & 2.51 & 21 & 43 & NA & NA \\
\hline Vinyl acetate & 9.27 & 83 & 170 & NA & NA \\
\hline \multicolumn{6}{|l|}{ Mustard } \\
\hline FIREPLUME & $4.6 \times 10^{-3}$ & $1 \times 10^{-4}$ & NA & $\begin{array}{l}1.4 \times 10^{-4} \text { to } \\
1.4 \times 10^{-2}\end{array}$ & $\begin{array}{l}1.2 \times 10^{-4} \text { to } \\
1.2 \times 10^{-2}\end{array}$ \\
\hline $\mathrm{D} 2 \mathrm{PC}$ & $3.4 \times 10^{-3}$ & $1 \times 10^{-4}$ & NA & $\begin{array}{l}1.4 \times 10^{-4} \text { to } \\
1.4 \times 10^{-2}\end{array}$ & $\begin{array}{l}1.2 \times 10^{-4} \text { to } \\
1.2 \times 10^{-2}\end{array}$ \\
\hline \multicolumn{6}{|l|}{ Phosgene } \\
\hline FIREPLUME & $2.2 \times 10^{-2}$ & 0.20 & NA & NA & NA \\
\hline $\mathrm{D} 2 \mathrm{PC}$ & $1.6 \times 10^{-2}$ & 0.20 & $\mathrm{NA}$ & NA & NA \\
\hline
\end{tabular}

a The maximum release concentration as predicted by FIREPLUME (except as noted); the 20-minute concentration from a stability E fire (see Section 8.2).

b $\mathrm{NA}=$ not applicable. 
Arsenic is a carcinogen, and a range of screening action levels is given. The calculated exposure for arsenic is higher than the $10^{-6}$ risk level, but lower than the $10^{-4}$ risk level. However, even though this calculated exposure is above the $10^{-6}$ level, a number of the assumptions used in calculating this exposure are very conservative and it is the authors' judgment that actual exposure levels would likely be significantly below this value. For example, we assumed that the most exposed individual would be located at the point of highest concentration for each of the five annual fires for either 12 or 30 years for a child or an adult, respectively. In addition, the source term was based on a single high value of contamination from the J-Field study. Actually, it is unlikely that any 25-acre site would have contamination levels this high over the entire area, and it is even more unlikely that there are large enough areas with contamination levels this high to provide for five 25 -acre fires a year for 12 or 30 years (1,500 acres of forested area contaminated at the high levels of the Toxic Burning Pits Push-Out Area of J-Field for the 12-year duration of the child exposure or 3,750 acres for the 30-year adult exposure). For comparison, APG as a whole contains only 13,000 total acres of forested area.

Calculated exposure levels for DU and TCE are orders of magnitude lower than the screening action levels. The calculated DU level is approximately four orders of magnitude $(10,000$ times) lower than the screening level, and the TCE level is four to six orders of magnitude $(10,000$ to $1,000,000$ times) lower than the screening levels. Carcinogenic risk levels for DU where not calculated because they are known to be lower than the noncarcinogenic risk (Davis 1990).

The two naturally occurring chemicals that are released from burning uncontaminated vegetation (2-furaldehyde and vinyl acetate) are both below their screening action levels by factors of about 10. Although a number of conservative assumptions apply to the levels calculated for these chemicals (e.g., the number of exposures and the area required to be burned), the actual contaminant amounts estimated to be released by the burning vegetation are less conservative than that for the anthropogenic contaminants. The amounts of 2-furaldehyde and vinyl acetate released from a 25 -acre fire are likely to be within an order of magnitude of the estimated release, while the actual amounts of the anthropogenic contaminants released could be several orders of magnitude below the estimated values.

Mustard is a carcinogen, and a range of screening action levels is given. The calculated exposure for mustard is higher than the $10^{-6}$ risk level and lower than the $10^{-4}$ risk level. As was the case for arsenic, several assumptions used in calculating the potential for mustard exposure are conservative. For example, the receptor was assumed to be located at the point of highest concentration for an annual fire over a period of 12 or 30 years. Although the calculated mustard exposure level is also 50 times higher than the noncarcinogen screening action level given, this action level value is not entirely applicable to the 1-hour exposure scenario evaluated for this study. The value of $0.0001 \mathrm{mg} / \mathrm{m}^{3}$ is the control limit given by the CDC for general population exposures of up to 72 hours duration (CDC 1988). In addition, the control limit was not a risk-based number 
and appears to incorporate a very large safety factor over levels observed to cause noncarcinogenic adverse effects (see Section 10.1.2).

\subsubsection{Soil Deposition}

Table 10 (Section 8.3) lists the results of soil deposition calculations. For these calculations, the deposition rate at the point of highest air concentration was used to determine soil deposition. We assumed a settling velocity of $5 \mathrm{~cm} / \mathrm{s}$, which is relatively high and provides total deposition estimates that should be higher than any experienced at APG. We assumed that the deposited contaminant mixed with the top $1 \mathrm{~cm}$ of soil and then calculated soil concentrations using this mixing assumption, as described in Section 8.3.

As shown in Table 10, the highest metal deposition occurs for lead, with a calculated soil concentration of $9.7 \times 10^{-4} \mathrm{mg} / \mathrm{kg}$. This value is less than the risk-based concentration guideline, $7.8 \times 10^{-3} \mathrm{mg} / \mathrm{kg}$, given by the EPA for residential soils (EPA 1994a, 1995c). The calculated arsenic concentration is four orders of magnitude lower than the suggested levels, and all other chemicals are even further below the suggested values.

On the basis of these preliminary deposition calculations, it appears that other exposure pathways, such as groundwater or ingestion, which would be expected to pose even lower risk than the inhalation pathway evaluated here, are not significant contributors to human health risk. 


\section{DISCUSSION OF RESULTS}

This study was designed to determine if range fires at APG pose potential risks for adverse impacts to human health. The study was not designed to calculate actual health risks from range fires; the intent was, instead, to use conservative assumptions to compute approximate risks from fires in contaminated areas in order to determine if further study was needed. Even with the conservative assumptions used in this screening survey, the exposure levels calculated in this study are below screening action levels for all the contaminants but arsenic and mustard. Calculated arsenic exposure levels are between the $10^{-6}$ and $10^{-4}$ risk levels suggested as acceptable by the EPA. A best estimate of actual exposure levels would be several orders of magnitude below those presented in this study because of the compounding nature of the conservative assumptions used in our calculations. Some of the more conservative assumptions used in the present analysis are given below:

- We used plant uptake ratios that were 1 to 3 orders of magnitude (10 to 1,000 times) larger than field-measured values at J-Field, and these field measured values were for the total plant (roots, stems, and leaves) of a species known to have high metal uptake ratios. We then used these ratios to estimate aboveground concentrations (just leaves and stems) in grasses and trees, even though most plants have much higher values in the roots that in the leaves and stems. Actual uptake is probably 10 to 1,000 times lower than estimated here.

- We estimated soil contaminant concentrations on the basis of the highest reasonable values known to occur at APG. These values were assumed to occur over sufficient area to burn 125 acres per year for either 12 or 30 years, although field data have not shown these highly contaminated areas to be this large. In fact, most of APG would have contaminant values significantly below those used in the study. Actual values are probably 2 to 10 times lower than the values used here.

- We estimated that five 25-acre fires would occur each year. This assumption was based on only the 30 fires for which size estimates were available in the database. This number of fires is much higher than the observed number of fires of this size that have occurred during the study period, which is approximately one 25 -acre fire every other year.

- We assumed that each of the five fires per year occurred in highly contaminated areas. 
- We assumed that the entire mass of a contaminant estimated to be in a plant would be released during the fire. There would be no residual contamination in the ash, and the contaminants would not be destroyed by the fire. In actual field conditions, some metal contamination would remain in the ash, and some of the organic contamination would be destroyed by the fire.

- We assumed that each of the five fires each year occurred during the worst possible meteorological conditions (i.e., the conditions resulting in the highest ground-level contamination values) and occurred under the field conditions that generated the highest ground-level contamination values.

In addition to the above conservative assumptions made to ensure that the estimated exposure levels would be higher than any actual occurrences at APG, our assumptions about the receptor (the exposed individual) were also designed to overpredict exposure. We assumed that the receptor would be present at the location of maximum ground-level contamination for one hour ( the duration of the fire) for each of the five annual fires for total periods of 12 years for children and 30 years for adults.

We made each of these assumptions on the basis of our knowledge of range fires at APG and to ensure that the exposure levels estimated in this study would be higher than any levels that could actually be expected to occur. As a result of these cumulatively conservative assumptions, the calculated exposure levels reported here are most likely several orders of magnitude higher than any actual exposures that would occur at APG.

We designed this study to determine whether exposure to the levels of contaminants contained in range fire smoke from APG could pose health risks to site workers or to the public. We used a wide range of assumptions to ensure that the exposures we calculated would be higher than any actually experienced in the field. Even with these assumptions, the exposure levels calculated were below levels of concern for every contaminant except arsenic and mustard. We calculated the exposure levels for these two contaminants to be above a $10^{-6}$ risk level, but below a $10^{-4}$ risk level. It is interesting to note that background (or natural) arsenic contamination levels in the area range up to $3.7 \mathrm{mg} / \mathrm{kg}$ (ICF-Kaiser Engineers 1995), which is only one order of magnitude below the value used for this study (i.e., $24 \mathrm{mg} / \mathrm{kg}$ ). On the basis of this high background level, fires in forested areas with this level of arsenic contamination could produce calculated risk levels in the range of the $10^{-6}$ (assuming the other conservative parameters used in this study). This result shows that the risk from nonanthropogenic contaminants is similar to the estimated risk, based on very conservative assumptions, from anthropogenic contaminants at APG.

Table 13 shows that with the exception of arsenic and mustard, the contaminant that was closest to the selected screening levels was vinyl acetate, a natural product of the vegetation, rather than any anthropogenic contamination at APG. In addition, although our assumed release levels for 
the natural vegetation chemicals are conservative, they are probably less conservative than the assumptions used for releases of the anthropogenic contaminants. Our assumptions for both natural and anthropogenic contaminants require 125 acres of forested area to burn each year. However, we feel that the estimated release rates we used in our calculations for the natural chemicals are within an order of magnitude ( 10 times) of the actual rates, while the estimated release rates we used for the anthropogenic contaminants are probably several orders of magnitude above the actual release levels. This finding suggests that the main source of human health risk from range fires at APG is most likely from the release of natural substances from burning vegetation itself, rather than release of anthropogenic contaminants, and that APG should focus on fire control as a risk-reduction method. Smaller, hotter fires (which occur on days when meteorological conditions do not result in a low plume that impacts the ground close to the fire), have much lower potential for human health impacts.

The study results are linearly dependent on the amount of biomass available (fire size, fire type, and time of year), the amount of a contaminant in the biomass, and the number of acres burned per year. If data were available for any of these parameters showing that actual values are lower than the values assumed in this report, the calculated ground-level exposure levels could be reduced proportionally. The effects of meteorological conditions and fire smoldering are not linear and would be more difficult to predict.

It is our conclusion that this study shows that the risk of adverse health effects from range fires at APG is extremely small. The study also defines how various parameters affect these estimated results and can help determine how to direct future studies to produce better estimates of actual health risks, rather than bounding calculations. 


\section{RECOMMENDATIONS}

We conclude that this study demonstrates that range fires at APG do not pose significant health risks to the surrounding population or to APG workers. Some risk does exist, but we believe that the exposure levels calculated for this report represent an upper bound of such risk, rather than good estimates of the actual exposures that might occur. It is our conclusion that while further study of this problem could provide better estimates of the actual exposures at APG, such estimates are not needed to evaluate the possibility of significant adverse health impacts. Nonetheless, if it is deemed important to develop more accurate estimates of human health risk from range fires at APG, the following studies or actions are recommended:

1. A field sampling program to determine the ratio of soil contaminant levels to aboveground plant concentrations. Such a study would provide data for improving the estimate of plant uptake ratios. Plant material collected during this study could be forwarded to the Forest Service Fire Laboratory for tests to determine the actual amount of a contaminant that would be released in a fire.

2. A study that estimates actual population risk. This study would include wind directions, population distributions, and probability of occurrence for various fire parameters.

3. A review of APG documents to compile an extensive database of soil contamination values. These data would then be used to estimate extent and levels of soil contamination and to better define the potential source term for plant uptake. This literature study should result in a much lower source term than the one used in this screening study and provide a more realistic assessment of the levels of contamination that could be expected in forested and grassland areas. Using this estimate, the probability that a fire would occur in an area with a contamination level above a given value could be estimated on the basis of the relative extent of the contaminated area and the entire range area at APG.

4. A change in fire record-keeping procedures for the APG Fire Department. Current records are designed for administrative uses and do not contain the detailed information needed for these types of exposure studies. Data such as fire size, fire duration, wind directions, estimated plume rise and touch down, fire material (grass, scrubs, wood, etc.), and fire behavior (e.g., smoldering, hot, etc.) would be beneficial for future studies. 
5. A study to evaluate other possible exposure pathways, such as exposure to contaminated groundwater and contaminant ingestion.

We do not, however, recommend any study involving use of instrumentation to collect data from actual range fires at APG at this time. Sampling strategies, uncertainty in the source terms and meteorology, and other factors would render data captured in such a study very difficult to evaluate. As part of the current study, we tried to correlate air samples collected during a separate range study of DU contamination with our model results. However, we found that such correlation was not possible. We recommend that if a study involving field sampling of actual fires is deemed necessary, (1) an extensive modeling effort should be used to help design the field sampling program and (2) an extensive field data collection effort to accurately define the source term should be undertaken before any field fire measurements are made. 


\section{REFERENCES}

Anderson, A., 1997, Personal communication from Anderson to A.M. Hermes, Environmental Assessment Division, Argonne National Laboratory, Argonne, Ill., Sept.

Agency for Toxic Substances and Disease Registry, 1992a, Toxicological Profile for DDT, DDE, and $D D D$, prepared by Clement International Corp. for U.S. Public Health Service.

Agency for Toxic Substances and Disease Registry, 1992b, Toxicological Profile for Mustard Gas, TP-91/22, prepared by Clement International Corp. for U.S. Public Health Service, Sept.

Agency for Toxic Substances and Disease Registry, 1993a, Toxicological Profile for Arsenic, TP-92/02, prepared by Life Systems Inc. under subcontract to Clement International Corporation for U.S. Public Health Service, April.

Agency for Toxic Substances and Disease Registry, 1993b, Toxicological Profile for Lead, TP-92/12, prepared by Clement International Corp. for U.S. Public Health Service, April.

ATSDR — See Agency for Toxic Substances and Disease Registry.

Barbour, M.G., and W.D. Billings (eds.), 1988, North American Terrestrial Vegetation, Cambridge University Press, New York, N.Y.

Bell, E.V., et al., 1927, "Decomposition of Some Halogenated Sulphides, and the Nature of the 'Polymeric' Ethylene Sulphides," Journal of the Chemical Society pp. 1803-1809.

Berry, W.L., and A. Wallace, 1974, Trace Elements in the Environment - Their Role and Potential Toxicity as Related to Fossil Fuels - A Preliminary Study, University of California, Laboratory of Nuclear Medicine and Radiation Biology.

Brown, D.F., 1997, An Improved Methodology for Characterizing Atmospheric Boundary Layer Turbulence and Dispersion, Ph.D. thesis, University of Illinois, Urbana, Ill.

Brown, D.F., et al., 1997, FIREPLUME Model for Plume Dispersion from Fires: Application to Uranium Hexafluoride Cylinder Fires, ANL/EAD/TM-69, Argonne, Ill., June.

Centers for Disease Control, 1988, "Final Recommendations for Protecting the Health and Safety against Potential Adverse Effects of Long-Term Exposure to Low Doses of Agents GA, GB, VX, Mustard Agent (H, HD, T) and Lewisite (L)," Department of Health and Human Services, Federal Register 53(50):8504, March 15. 
Davis, L.S., 1990, Environmental Assessment for Testing Uranium Penetrator Munitions at U.S. Army Combat Systems Test Activity, Aberdeen Proving Ground, Aberdeen, Md.

$\mathrm{CDC}$ - see Centers for Disease Control.

Directorate of Safety, Health and Environment, 1994, Installation Restoration Action Plan, Aberdeen Proving Ground, Maryland, Jan.

DSHE - See Directorate of Safety, Health and Environment.

Dvorak, A.J., et al., 1978, Impacts of Coal-Fired Plants on Fish, Wildlife, and Their Habitats, FWS/OBS-78/29, prepared by Argonne National Laboratory, Argonne, Ill., for the Office of Biological Services and Environmental Contaminants Evaluation, Fish and Wildlife Service, U.S. Department of the Interior.

Ebinger, M.H., et al., 1996, Long-Term Fate of Depleted Uranium at Aberdeen and Yuma Proving Ground, Phase II: Human Health and Ecological Risk Assessments, LA 13156-MS, Los Alamos National Laboratory, New Mexico.

Eisler, R., 1988a, Arsenic Hazards to Fish, Wildlife, and Invertebrates: A Synoptic Review, Biological Report 85 (1.11), U.S. Fish and Wildlife Service, Patuxent Center, Laurel, Md.

Eisler, R., 1988b, Lead Hazards to Fish, Wildlife, and Invertebrates: A Synoptic Review, Biological Report 85(1.12), U.S. Fish and Wildlife Service, Patuxent Wildlife Research Center, Laurel, Md.

EPA - See U.S. Environmental Protection Agency.

General Physics Corporation, 1992, Comprehensive Natural Resources Management Plan, U.S. Army Aberdeen Proving Ground; Volume I: Overall Objectives, Management History, Goals, Strategies, and Suggested Projects, prepared for the U.S. Army, Aberdeen Proving Ground, Md.

General Physics Corporation, 1997, Carroll Island Study Area, Test Grid 1 Soil Sampling Results, prepared by General Physics Corporation, Edgewood, Md., for U.S. Army, Aberdeen Proving Ground, Md.

Gibbs, R., and M. Miller, 1996, Chemical and Biological Modeling Process Action (PAT) Modeling Subgroup Final Report, prepared for the Assistant to the Secretary of Defense, Nuclear, Chemical, and Biological, Chemical and Biological Matters, and Deputy Under Secretary of the Army Operations Research, U.S. Department of Defense, Washington, D.C. 
Hlohowskyj, I., et al., 1996, Remedial Investigation Report for J-Field, Aberdeen Proving Ground, Maryland, Volume 3: Ecological Risk Assessment, Draft, Argonne National Laboratory, Argonne, Ill., Jan.

Hodgson, J.F., 1970, "Chemistry of Trace Elements in Soils with Reference to Trace Element Concentration in Plants," pp. 45-58, in D.D. Hemphill (ed.), Proceedings of the University of Missouri's 3rd Annual (1969) Conference on Trace Substances in Environmental Health, Vol. III, University of Missouri Press, Columbia, Mo.

Hope, B.K., 1995, "A Review of Models for Estimating Terrestrial Ecological Receptor Exposure to Chemical Contaminants," Chemosphere 30(12):2267-2287.

ICF-Kaiser Engineers, 1995, Reference Sampling and Analysis Program at the U.S. Army Aberdeen Proving Ground, Soil, Sediment, and Surface Water Reference Data Report, prepared for U.S. Army Environmental Center, Aberdeen Proving Ground, Md., July.

Jastrow, J.D., 1995, Feasibility of Using Plants to Assist in the Remediation of Heavy Metal Contamination at J-Field, Aberdeen Proving Ground, Maryland, Argonne National Laboratory, Argonne, Ill.

Jones, C., 1997, personal communication from Jones (Fire Chief, Aberdeen Proving Ground) to A.M. Hermes (Argonne National Laboratory, Argonne, Ill.), July.

Kabata-Pendias, A., 1992, Trace Elements in Soils and Plants, 2nd ed., CRC Press, Inc., Ann Arbor, Mich.

Liljegren, J.C., 1989, The Atterbury-87 Field Study of Smoke Dispersion and a New Stochastic Dispersion Model, Ph.D. thesis, Department of Mechanical Engineering, University of Illinois, Urbana, Ill.

Los Alamos National Laboratory, Long-Term Fate of Depleted Uranium at Aberdeen and Yuma Proving Grounds, Phase II: Human Health and Ecological Risk Assessments, LA-13156-MS, Los Alamos National Laboratory, Albuquerque, N.M., Sept.

Mackay, D., 1991, Multimedia Environmental Models: The Fugacity Approach, Lewis Publishers, Inc., Chelsea, Mich.

Marrs, T.C., et al., 1996, Chemical Warfare Agents, Toxicology and Treatment, John Wiley \& Sons, Ltd., West Sussex, England. 
McKenzie, L.M., et al., 1995, "Measurement and Modeling of Air Toxins from Smoldering Combustion of Biomass," Environmental Science and Technology 29(8):2047-2054.

National Council on Radiation Protection and Measurement, 1984, Radiological Assessment: Predicting the Transport, Bioaccumulation, and Uptake by Man of Radionuclides Released to the Environment, Report No. 76, National Council on Radiation Protection and Measurements.

NCRP - See National Council on Radiation Protection and Measurement.

Richards, G.M., 1997, personal communication from Richards (University of Illinois, ChampaignUrbana, Ill.) to A. Policastro (Argonne National Laboratory, Argonne, Ill.).

Rynders, D.G., 1995, Investigation of Depleted Uranium Offsite from a Military Ordnance Range: Potential Concentrations and Radiological Doses, thesis submitted to Oregon State University.

Sax, N.I., and R.J. Lewis, Sr., 1989, Dangerous Properties of Industrial Materials, 7th edition, Van Nostrand Reinhold, New York, N.Y.

Sleicher, C., and J. Hopcraft, 1984, "Persistence of Pesticides in Surface Soil and Relation to Sublimation," Environmental Science and Technology 18:514-518.

Strenge, D.L., and S.R. Peterson, 1989, Chemical Data Bases for the Multimedia Environmental Assessment System (MEPAS): Version 1, PNL-7145, prepared by Pacific Northwest Laboratory for the U.S. Department of Energy.

SWCA, Inc., 1994, Biological Assessment for Aberdeen Proving Ground, Maryland, final draft, prepared by SWCA, Inc., Environmental Consultants, Flagstaff, Ariz., for the Directorate of Safety, Health and the Environment, Aberdeen Proving Ground, Md., Dec.

Travis, C.C., and A.D. Arms, 1988, "Bioconcentration of Organics in Beef, Milk, and Vegetation," Environmental Science and Technology 24:829-837.

Turner, D.B., 1969, Workbook of Atmospheric Deposition Estimates, AP-26, U.S. Environmental Protection Agency, Office of Air Programs, Washington, D.C.

U.S. Department of the Army, 1987, Natural Resources Management Plan, Part II, LandManagement and Ground Maintenance, Aberdeen Proving Ground, Md.

U.S. Environmental Protection Agency, 1986, Health Assessment Document for Phosgene, Review Draft, EPA/600/8-86/022A, Office of Health and Environmental Assessment, Washington, D.C., Aug. 
U.S. Environmental Protection Agency, 1989, Risk Assessment Guidance for Superfund; Volume I: Human Health Evaluation Manual (Part A, Interim Final), EPA/540/1-89/001, Office of Emergency and Remedial Response, Washington, D.C., Dec.

U.S. Environmental Protection Agency, 1990, "National Oil and Hazardous Substances Pollution Contingency Plan; Final Rule (400 CFR Part 300)," Federal Register 55(35):6154-6176, Feb. 21.

U.S. Environmental Protection Agency, 1991a, Risk Assessment Guidance for Superfund; Volume I: Human Health Evaluation Manual, Part A: Supplemental Guidance, "Standard Default Exposure Factors," Interim Final, OSWER Directive 9285.6-03, Office of Emergency and Remedial Response, Washington, D.C., March 25.

U.S. Environmental Protection Agency, 1991b, Risk Assessment Guidance for Superfund; Volume I: Human Health Evaluation Manual, Part B: Development of Risk-Based Preliminary Remediation Goals, EPA/540/R-92/003, Office of Emergency and Remedial Response, Washington, D.C., Dec.

U.S. Environmental Protection Agency, 1991c, Upper-Bound Quantitative Cancer Risk Estimate for Populations Adjacent to Sulfur Mustard Incineration Facilities, EPA/600/8-91/053, Office of Research and Development, Washington, D.C., July.

U.S. Environmental Protection Agency, 1994a "Risk-Based Concentration Table, Fourth Quarter 1994," Philadelphia, Pa.

U.S. Environmental Protection Agency, 1994b, Integrated Exposure Uptake Biokinetic (IEUBK) Model, Version 0.99d, Washington, D.C., March 8.

U.S. Environmental Protection Agency, 1995a, Exposure Factors Handbook, Review Draft, EPA/600/P-95/002A, Office of Research and Development, Washington, D.C., June.

U.S. Environmental Protection Agency, 1995b, Health Effects Assessment Summary Tables FY 1995 Annual, EPA/540/R-95/036, Office of Solid Waste and Emergency Response, May.

U.S. Environmental Protection Agency, 1995c, "Risk-Based Concentration Table, July - December 1995, "Philadelphia, Pa.

U.S. Environmental Protection Agency, 1996, Risk Assessment Issue Paper for Carcinogenicity Information for Trichloroethylene (TCE) (CASRN 79-01-6), Superfund Health Risk Technical Support Center, Washington, D.C.

U.S. Environmental Protection Agency, 1997, Integrated Risk Information System, Office of Research and Development, database, accessed in Feb. 
Vaughn, B.E., et al., 1975, Review of the Potential Impact on Health and Environmental Quality from Metals Entering the Environment as a Result of Coal Utilization, Battelle Energy Progress Report, Pacific Northwest Laboratories-Battelle Memorial Institute, Richland, Wash.

Willis, D.J., and J.W. Deardorff, 1977, "A Laboratory Model of the Unstable Planetary Boundary Layer," Journal of Atmospheric Sciences 31:1297-1307.

Yuen, C.R., et al., 1996, Remedial Investigation Report for J-Field, Aberdeen Proving Ground, Maryland; Volume 1: Remedial Investigation Results, Draft, Argonne National Laboratory, Argonne, Ill. 
A-1

APPENDIX A:

FIREPLUME MODEL RESULTS 
A-2 


\section{APPENDIX A:}

\section{FIREPLUME MODEL RESULTS}

This appendix contains the output data from the FIREPLUME model for the APG range fires study. The concentrations given here are for six model runs (Tables A.1 through A.6): atmospheric stability classes A, D, and E, in both forest and field fire situations. Stability A represents conditions of low wind speed and strong vertical mixing, typical of a clear summer afternoon with low winds. Stability D represents neutral conditions (on the slightly stable side), as would be typical of late afternoon or early morning overcast periods with moderate winds. Stability E represents a nighttime case with partial cloud cover and moderate winds. The specific parameters for each scenario are listed (in footnotes) along with the corresponding output. The concentrations are given in units of $\mathrm{mg} / \mathrm{m}^{3}$ per $\mathrm{kg}$ of contaminant release. To determine the final ground concentrations from each plume in $\mathrm{mg} / \mathrm{m}^{3}$, the data were multiplied by the estimated total contaminant release, in $\mathrm{kg}$, for each contaminant. The "sigma $\mathrm{Y}$ " values allow calculation of concentrations off the centerline, as detailed in Section 8.2. 
TABLE A.1 Predicted Normalized Ground-Level Concentrations for Forest Fire, Stability Class $\mathbf{A}^{\text {a }}$

\begin{tabular}{|c|c|c|c|}
\hline \multirow{2}{*}{$\begin{array}{l}\text { Distance } \\
\text { (m) }\end{array}$} & \multicolumn{2}{|c|}{$\begin{array}{c}\text { Ground-Level Concentration } \\
\left(\left[\mathrm{mg} / \mathrm{m}^{3}\right] \text { per } \mathrm{kg}\right. \\
\text { contaminant released })\end{array}$} & \multirow[b]{2}{*}{ Sigma $Y(\mathrm{~cm})$} \\
\hline & 20 Minutes & 60 Minutes & \\
\hline 50 & $3.16 \mathrm{E}-09$ & $3.16 \mathrm{E}-09$ & 106.996 \\
\hline 100 & $1.84 \mathrm{E}-08$ & $1.82 \mathrm{E}-08$ & 119.183 \\
\hline 150 & $6.21 \mathrm{E}-08$ & $6.15 \mathrm{E}-08$ & 119.705 \\
\hline 200 & $1.67 \mathrm{E}-07$ & $1.65 \mathrm{E}-07$ & 120.471 \\
\hline 250 & $3.61 \mathrm{E}-07$ & $3.57 \mathrm{E}-07$ & 122.182 \\
\hline 300 & $6.49 \mathrm{E}-07$ & $6.39 \mathrm{E}-07$ & 127.505 \\
\hline 400 & $1.30 \mathrm{E}-06$ & $1.27 \mathrm{E}-06$ & 148.399 \\
\hline 500 & $1.94 \mathrm{E}-06$ & $1.88 \mathrm{E}-06$ & 181.684 \\
\hline 600 & $2.92 \mathrm{E}-06$ & $2.80 \mathrm{E}-06$ & 213.165 \\
\hline 700 & $4.38 \mathrm{E}-06$ & 4.19E-06 & 241.474 \\
\hline 800 & $6.55 \mathrm{E}-06$ & $6.31 \mathrm{E}-06$ & 267.839 \\
\hline 900 & $9.88 \mathrm{E}-06$ & $9.56 \mathrm{E}-06$ & 287.548 \\
\hline 1,000 & $1.46 \mathrm{E}-05$ & $1.42 \mathrm{E}-05$ & 301.235 \\
\hline 1,250 & $3.06 \mathrm{E}-05$ & $2.95 \mathrm{E}-05$ & 327.903 \\
\hline 1,500 & $4.60 \mathrm{E}-05$ & $4.40 \mathrm{E}-05$ & 359.541 \\
\hline 1,750 & $5.83 \mathrm{E}-05$ & 5.51E-05 & 401.072 \\
\hline 2,000 & 7.19E-05 & $6.76 \mathrm{E}-05$ & 446.954 \\
\hline 2,500 & $1.14 \mathrm{E}-04$ & $1.08 \mathrm{E}-04$ & 521.402 \\
\hline 3,000 & $1.55 \mathrm{E}-04$ & $1.46 \mathrm{E}-04$ & 573.628 \\
\hline 3,500 & $1.64 \mathrm{E}-04$ & $1.54 \mathrm{E}-04$ & 622.714 \\
\hline 4,000 & $1.46 \mathrm{E}-04$ & 1.35E-04 & 678.439 \\
\hline 4,500 & $1.22 \mathrm{E}-04$ & $1.12 \mathrm{E}-04$ & 743.122 \\
\hline 5,000 & 1.05E-04 & 9.53E-05 & 812.499 \\
\hline 6,000 & $8.78 \mathrm{E}-05$ & $7.87 \mathrm{E}-05$ & 944.813 \\
\hline 7,000 & 7.78E-05 & $6.89 \mathrm{E}-05$ & 1068.75 \\
\hline 8,000 & $6.98 \mathrm{E}-05$ & $6.13 \mathrm{E}-05$ & 1189.82 \\
\hline 9,000 & $6.29 \mathrm{E}-05$ & $5.47 \mathrm{E}-05$ & 1309.78 \\
\hline 10,000 & 5.71E-05 & $4.92 \mathrm{E}-05$ & 1430.53 \\
\hline 12,500 & $4.68 \mathrm{E}-05$ & $4.00 \mathrm{E}-05$ & 1725.29 \\
\hline 15,000 & $3.84 \mathrm{E}-05$ & $3.28 \mathrm{E}-05$ & 2015.37 \\
\hline 17,500 & 3.19E-05 & $2.74 \mathrm{E}-05$ & 2306.02 \\
\hline 20,000 & $2.69 \mathrm{E}-05$ & 2.33E-05 & 2590.85 \\
\hline
\end{tabular}

a Parameters: wind $=2.00000 ; \mathrm{w}^{*}=1.53698$;

$\mathrm{L}=-10.00000 ; \mathrm{Zi}=500.000 ;$ time $=60$ minute fire. 
TABLE A.2 Predicted Normalized Ground-Level Concentrations for Forest Fire, Stability Class $D^{\mathbf{a}}$

\begin{tabular}{|c|c|c|c|}
\hline \multirow{2}{*}{$\begin{array}{l}\text { Distance } \\
(\mathrm{m})\end{array}$} & \multicolumn{2}{|c|}{$\begin{array}{c}\text { Ground-Level } \\
\text { Concentration }\left(\left[\mathrm{mg} / \mathrm{m}^{3}\right] \text { per }\right. \\
\mathrm{kg} \text { contaminant released })\end{array}$} & \multirow[b]{2}{*}{ Sigma $Y(\mathrm{~cm})$} \\
\hline & 20 Minutes & 60 Minutes & \\
\hline 50 & $3.06 \mathrm{E}-05$ & $3.06 \mathrm{E}-05$ & 31.4191 \\
\hline 100 & 0 & 0 & 30 \\
\hline 150 & 0 & 0 & 30 \\
\hline 200 & 0 & 0 & 30 \\
\hline 250 & $5.80 \mathrm{E}-09$ & 5.80E-09 & 63.8498 \\
\hline 300 & $1.17 \mathrm{E}-07$ & $1.17 \mathrm{E}-07$ & 65.8894 \\
\hline 400 & $3.26 \mathrm{E}-06$ & $3.25 \mathrm{E}-06$ & 68.6746 \\
\hline 500 & $1.28 \mathrm{E}-05$ & $1.27 \mathrm{E}-05$ & 74.6951 \\
\hline 600 & $2.54 \mathrm{E}-05$ & $2.53 \mathrm{E}-05$ & 84.0901 \\
\hline 700 & $4.37 \mathrm{E}-05$ & 4.36E-05 & 92.9038 \\
\hline 800 & $6.18 \mathrm{E}-05$ & $6.16 \mathrm{E}-05$ & 100.5972 \\
\hline 900 & $7.40 \mathrm{E}-05$ & $7.36 \mathrm{E}-05$ & 109.231 \\
\hline 1,000 & $8.81 \mathrm{E}-05$ & $8.76 \mathrm{E}-05$ & 118.162 \\
\hline 1,250 & $1.18 \mathrm{E}-04$ & $1.18 \mathrm{E}-04$ & 137.283 \\
\hline 1,500 & $1.29 \mathrm{E}-04$ & $1.28 \mathrm{E}-04$ & 156.828 \\
\hline 1,750 & $1.38 \mathrm{E}-04$ & $1.37 \mathrm{E}-04$ & 174.88 \\
\hline 2,000 & $1.42 \mathrm{E}-04$ & $1.41 \mathrm{E}-04$ & 192.538 \\
\hline 2,500 & $1.50 \mathrm{E}-04$ & $1.49 \mathrm{E}-04$ & 228.16 \\
\hline 3,000 & $1.44 \mathrm{E}-04$ & $1.42 \mathrm{E}-04$ & 274.091 \\
\hline 3,500 & $1.28 \mathrm{E}-04$ & $1.26 \mathrm{E}-04$ & 331.688 \\
\hline 4,000 & $1.12 \mathrm{E}-04$ & $1.10 \mathrm{E}-04$ & 391.092 \\
\hline 4,500 & $9.89 \mathrm{E}-05$ & $9.69 \mathrm{E}-05$ & 453.397 \\
\hline 5,000 & $8.91 \mathrm{E}-05$ & $8.70 \mathrm{E}-05$ & 517.214 \\
\hline 6,000 & $7.44 \mathrm{E}-05$ & $7.23 \mathrm{E}-05$ & 645.567 \\
\hline 7,000 & $6.12 \mathrm{E}-05$ & $5.91 \mathrm{E}-05$ & 777.626 \\
\hline 8,000 & $5.11 \mathrm{E}-05$ & $4.90 \mathrm{E}-05$ & 915.218 \\
\hline 9,000 & $4.38 \mathrm{E}-05$ & 4.17E-05 & 1055.77 \\
\hline 10,000 & $3.83 \mathrm{E}-05$ & $3.62 \mathrm{E}-05$ & 1197.65 \\
\hline 12,500 & $2.82 \mathrm{E}-05$ & $2.62 \mathrm{E}-05$ & 1557.97 \\
\hline 15,000 & $2.16 \mathrm{E}-05$ & $1.98 \mathrm{E}-05$ & 1931.46 \\
\hline 17,500 & $1.72 \mathrm{E}-05$ & $1.54 \mathrm{E}-05$ & 2311.75 \\
\hline 20,000 & $1.41 \mathrm{E}-05$ & $1.25 \mathrm{E}-05$ & 2693.21 \\
\hline
\end{tabular}

a Parameters: wind $=5.00000 ; \mathrm{u}^{*}=0.500000$;

$\mathrm{L}=450.000 ; \mathrm{Zi}=500.000 ;$ time $=60$ minute fire. 
TABLE A.3 Predicted Normalized Ground-Level Concentrations for Forest Fire, Stability Class $\mathbf{E}^{\mathbf{a}}$

\begin{tabular}{|c|c|c|c|}
\hline \multirow{2}{*}{$\begin{array}{l}\text { Distance } \\
\text { (m) }\end{array}$} & \multicolumn{2}{|c|}{$\begin{array}{c}\text { Ground-Level } \\
\text { Concentration }\left(\left[\mathrm{mg} / \mathrm{m}^{3}\right] \text { per }\right. \\
\mathrm{kg} \text { contaminant released })\end{array}$} & \multirow[b]{2}{*}{ Sigma Y $(\mathrm{cm})$} \\
\hline & 20 Minutes & 60 Minutes & \\
\hline 50 & 0 & 0 & 30 \\
\hline 100 & 0 & 0 & 30 \\
\hline 150 & 0 & 0 & 30 \\
\hline 200 & 0 & 0 & 30 \\
\hline 250 & $1.76 \mathrm{E}-09$ & $1.76 \mathrm{E}-09$ & 48.5745 \\
\hline 300 & $3.42 \mathrm{E}-07$ & $3.42 \mathrm{E}-07$ & 50.6604 \\
\hline 400 & $1.78 \mathrm{E}-05$ & $1.78 \mathrm{E}-05$ & 52.3149 \\
\hline 500 & $3.24 \mathrm{E}-05$ & $3.23 \mathrm{E}-05$ & 58.1719 \\
\hline 600 & $7.09 \mathrm{E}-05$ & $7.06 \mathrm{E}-05$ & 64.6797 \\
\hline 700 & $1.07 \mathrm{E}-04$ & $1.06 \mathrm{E}-04$ & 70.5246 \\
\hline 800 & $1.31 \mathrm{E}-04$ & $1.30 \mathrm{E}-04$ & 76.5282 \\
\hline 900 & $1.58 \mathrm{E}-04$ & $1.57 \mathrm{E}-04$ & 82.8195 \\
\hline 1,000 & $1.93 \mathrm{E}-04$ & $1.91 \mathrm{E}-04$ & 88.7401 \\
\hline 1,250 & $2.59 \mathrm{E}-04$ & $2.57 \mathrm{E}-04$ & 102.7231 \\
\hline 1,500 & $2.93 \mathrm{E}-04$ & $2.91 \mathrm{E}-04$ & 116.505 \\
\hline 1,750 & $3.13 \mathrm{E}-04$ & $3.10 \mathrm{E}-04$ & 134.982 \\
\hline 2,000 & 3.07E-04 & $3.04 \mathrm{E}-04$ & 157.63 \\
\hline 2,500 & $2.78 \mathrm{E}-04$ & $2.74 \mathrm{E}-04$ & 207.296 \\
\hline 3,000 & $2.67 \mathrm{E}-04$ & $2.62 \mathrm{E}-04$ & 260.201 \\
\hline 3,500 & $2.50 \mathrm{E}-04$ & $2.44 \mathrm{E}-04$ & 311.89 \\
\hline 4,000 & $2.24 \mathrm{E}-04$ & $2.18 \mathrm{E}-04$ & 367.83 \\
\hline 4,500 & $2.06 \mathrm{E}-04$ & $1.99 \mathrm{E}-04$ & 424.239 \\
\hline 5,000 & $1.92 \mathrm{E}-04$ & $1.85 \mathrm{E}-04$ & 482.869 \\
\hline 6,000 & $1.71 \mathrm{E}-04$ & $1.64 \mathrm{E}-04$ & 598.605 \\
\hline 7,000 & $1.49 \mathrm{E}-04$ & $1.41 \mathrm{E}-04$ & 719.073 \\
\hline 8,000 & $1.31 \mathrm{E}-04$ & $1.23 \mathrm{E}-04$ & 840.925 \\
\hline 9,000 & $1.16 \mathrm{E}-04$ & $1.08 \mathrm{E}-04$ & 966.552 \\
\hline 10,000 & $1.05 \mathrm{E}-04$ & $9.65 \mathrm{E}-05$ & 1094.34 \\
\hline $12,5,00$ & $8.49 \mathrm{E}-05$ & $7.61 \mathrm{E}-05$ & 1418.83 \\
\hline 15,000 & $7.06 \mathrm{E}-05$ & $6.21 \mathrm{E}-05$ & 1744.81 \\
\hline 17,500 & $5.84 \mathrm{E}-05$ & $5.05 \mathrm{E}-05$ & 2081.13 \\
\hline 20,000 & $4.97 \mathrm{E}-05$ & $4.26 \mathrm{E}-05$ & 2420.29 \\
\hline
\end{tabular}

a Parameters: wind $=3.00000 ; \mathrm{u}^{*}=0.250000$; $\mathrm{L}=60.0000 ; \mathrm{Zi}=140.000 ;$ time $=60$ minute fire. 
TABLE A.4 Predicted Normalized Ground-Level Concentrations for Field Fire, Stability Class $\mathbf{A}^{\mathrm{a}}$

\begin{tabular}{|c|c|c|c|}
\hline \multirow{2}{*}{$\begin{array}{l}\text { Distance } \\
(\mathrm{m})\end{array}$} & \multicolumn{2}{|c|}{$\begin{array}{c}\text { Ground-Level } \\
\text { Concentration }\left(\left[\mathrm{mg} / \mathrm{m}^{3}\right] \text { per }\right. \\
\text { kg contaminant released })\end{array}$} & \multirow[b]{2}{*}{ Sigma $Y(\mathrm{~cm}$} \\
\hline & 20 Minutes & 60 Minutes & \\
\hline 50 & 8.24E-06 & $8.24 \mathrm{E}-06$ & 32.1149 \\
\hline 100 & $5.86 \mathrm{E}-07$ & $5.79 \mathrm{E}-07$ & 94.61 \\
\hline 150 & $2.25 \mathrm{E}-06$ & $2.21 \mathrm{E}-06$ & 102.3541 \\
\hline 200 & $5.46 \mathrm{E}-06$ & $5.35 \mathrm{E}-06$ & 110.1 \\
\hline 250 & $9.66 \mathrm{E}-06$ & $9.41 \mathrm{E}-06$ & 121.971 \\
\hline 300 & $1.45 \mathrm{E}-05$ & $1.40 \mathrm{E}-05$ & 138.869 \\
\hline 400 & $2.97 \mathrm{E}-05$ & $2.90 \mathrm{E}-05$ & 171.695 \\
\hline 500 & $6.02 \mathrm{E}-05$ & $5.89 \mathrm{E}-05$ & 189.78 \\
\hline 600 & $1.07 \mathrm{E}-04$ & $1.05 \mathrm{E}-04$ & 201.265 \\
\hline 700 & $1.61 \mathrm{E}-04$ & $1.57 \mathrm{E}-04$ & 211.949 \\
\hline 800 & $2.10 \mathrm{E}-04$ & $2.05 \mathrm{E}-04$ & 223.386 \\
\hline 900 & $2.45 \mathrm{E}-04$ & 2.39E-04 & 235.948 \\
\hline 1,000 & $2.65 \mathrm{E}-04$ & $2.58 \mathrm{E}-04$ & 249.723 \\
\hline 1,250 & $2.66 \mathrm{E}-04$ & $2.58 \mathrm{E}-04$ & 288.68 \\
\hline 1,500 & $2.48 \mathrm{E}-04$ & $2.38 \mathrm{E}-04$ & 330.284 \\
\hline 1,750 & 2.31E-04 & $2.21 \mathrm{E}-04$ & 370.559 \\
\hline 2,000 & $2.16 \mathrm{E}-04$ & $2.06 \mathrm{E}-04$ & 408.972 \\
\hline 2,500 & $1.89 \mathrm{E}-04$ & $1.79 \mathrm{E}-04$ & 481.623 \\
\hline 3,000 & $1.64 \mathrm{E}-04$ & $1.54 \mathrm{E}-04$ & 550.135 \\
\hline 3,500 & $1.41 \mathrm{E}-04$ & $1.32 \mathrm{E}-04$ & 617.839 \\
\hline 4,000 & $1.24 \mathrm{E}-04$ & $1.14 \mathrm{E}-04$ & 686.174 \\
\hline 4,500 & $1.11 \mathrm{E}-04$ & $1.02 \mathrm{E}-04$ & 753.786 \\
\hline 5,000 & $1.03 \mathrm{E}-04$ & $9.32 \mathrm{E}-05$ & 819.049 \\
\hline 6,000 & $8.92 \mathrm{E}-05$ & $8.01 \mathrm{E}-05$ & 944.29 \\
\hline 7,000 & $7.84 \mathrm{E}-05$ & $6.95 \mathrm{E}-05$ & 1067.34 \\
\hline 8,000 & $6.98 \mathrm{E}-05$ & $6.12 \mathrm{E}-05$ & 1189.25 \\
\hline 9,000 & $6.28 \mathrm{E}-05$ & $5.46 \mathrm{E}-05$ & 1310.24 \\
\hline 10,000 & 5.71E-05 & $4.94 \mathrm{E}-05$ & 1429.91 \\
\hline 12,500 & 4.60E-05 & $3.93 \mathrm{E}-05$ & 1725.47 \\
\hline 15,000 & $3.82 \mathrm{E}-05$ & $3.26 \mathrm{E}-05$ & 2019.21 \\
\hline 17,500 & $3.23 \mathrm{E}-05$ & 2.77E-05 & 2305.74 \\
\hline 20,000 & $2.72 \mathrm{E}-05$ & $2.35 \mathrm{E}-05$ & 2590.48 \\
\hline
\end{tabular}

a Parameters: wind $=2.00000 ; \mathrm{w}^{*}=1.53698$;

$\mathrm{L}=-10.00000 ; \mathrm{Zi}=500.000$; time $=60 \mathrm{~min}$ fire. 
TABLE A.5 Predicted Normalized Ground-Level Concentrations for Field Fire, Stability Class $\mathbf{A}^{\mathrm{a}}$

\begin{tabular}{|c|c|c|c|}
\hline \multirow{2}{*}{$\begin{array}{l}\text { Distance } \\
(\mathrm{m})\end{array}$} & \multicolumn{2}{|c|}{$\begin{array}{c}\text { Ground-Level } \\
\text { Concentration }\left(\left[\mathrm{mg} / \mathrm{m}^{3}\right] \text { per }\right. \\
\text { kg contaminant released })\end{array}$} & \multirow[b]{2}{*}{ Sigma $Y(\mathrm{~cm})$} \\
\hline & 20 Minutes & 60 Minutes & \\
\hline 50 & $1.29 \mathrm{E}-03$ & $1.29 \mathrm{E}-03$ & 31.2225 \\
\hline 100 & 2.39E-04 & 2.39E-04 & 33.7647 \\
\hline 150 & $1.20 \mathrm{E}-04$ & $1.20 \mathrm{E}-04$ & 37.2155 \\
\hline 200 & $7.40 \mathrm{E}-05$ & $7.40 \mathrm{E}-05$ & 41.4539 \\
\hline 250 & $4.71 \mathrm{E}-05$ & 4.71E-05 & 46.6432 \\
\hline 300 & $6.15 \mathrm{E}-05$ & $6.14 \mathrm{E}-05$ & 54.0296 \\
\hline 400 & $1.85 \mathrm{E}-04$ & $1.85 \mathrm{E}-04$ & 63.8145 \\
\hline 500 & $3.17 \mathrm{E}-04$ & $3.17 \mathrm{E}-04$ & 72.254 \\
\hline 600 & $4.05 E-04$ & $4.04 \mathrm{E}-04$ & 81.5892 \\
\hline 700 & 4.77E-04 & $4.76 \mathrm{E}-04$ & 90.4898 \\
\hline 800 & $5.20 \mathrm{E}-04$ & $5.19 \mathrm{E}-04$ & 99.1938 \\
\hline 900 & $5.43 \mathrm{E}-04$ & $5.41 \mathrm{E}-04$ & 107.702 \\
\hline 1,000 & 5.47E-04 & $5.45 \mathrm{E}-04$ & 115.935 \\
\hline 1,250 & $5.20 \mathrm{E}-04$ & $5.17 \mathrm{E}-04$ & 136.48 \\
\hline 1,500 & $5.10 \mathrm{E}-04$ & $5.07 \mathrm{E}-04$ & 155.852 \\
\hline 1,750 & 4.87E-04 & $4.84 \mathrm{E}-04$ & 174.036 \\
\hline 2,000 & 4.54E-04 & $4.50 \mathrm{E}-04$ & 191.411 \\
\hline 2,500 & $3.79 \mathrm{E}-04$ & $3.75 \mathrm{E}-04$ & 226.385 \\
\hline 3,000 & $3.11 \mathrm{E}-04$ & 3.07E-04 & 272.482 \\
\hline 3,500 & $2.52 \mathrm{E}-04$ & $2.48 \mathrm{E}-04$ & 329.837 \\
\hline 4,000 & $2.11 \mathrm{E}-04$ & $2.07 \mathrm{E}-04$ & 389.666 \\
\hline 4,500 & $1.78 \mathrm{E}-04$ & $1.75 \mathrm{E}-04$ & 450.835 \\
\hline 5,000 & $1.53 \mathrm{E}-04$ & $1.50 \mathrm{E}-04$ & 513.784 \\
\hline 6,000 & $1.16 \mathrm{E}-04$ & $1.13 \mathrm{E}-04$ & 641.479 \\
\hline 7,000 & 9.03E-05 & $8.71 \mathrm{E}-05$ & 773.814 \\
\hline 8,000 & 7.23E-05 & $6.93 \mathrm{E}-05$ & 910.241 \\
\hline 9,000 & $5.95 \mathrm{E}-05$ & $5.67 \mathrm{E}-05$ & 1049.6 \\
\hline 10,000 & $5.03 \mathrm{E}-05$ & 4.76E-05 & 1192.02 \\
\hline 12,500 & $3.53 \mathrm{E}-05$ & $3.29 \mathrm{E}-05$ & 1553.85 \\
\hline 15,000 & $2.64 \mathrm{E}-05$ & $2.42 \mathrm{E}-05$ & 1926.2 \\
\hline 17,500 & $2.05 \mathrm{E}-05$ & $1.85 \mathrm{E}-05$ & 2301.49 \\
\hline 20,000 & 1.64E-05 & $1.45 \mathrm{E}-05$ & 2679.67 \\
\hline
\end{tabular}

a Parameters: wind $=5.00000 ; \mathrm{u}^{*}=0.500000$;

$\mathrm{L}=450.000 ; \mathrm{Zi}=500.000 ;$ time $=60 \mathrm{~min}$ fire. 
TABLE A.6 Predicted Normalized Ground-Level Concentrations for Field Fire, Stability Class $\mathrm{E}^{\mathrm{a}}$

\begin{tabular}{|c|c|c|c|}
\hline \multirow{2}{*}{$\begin{array}{l}\text { Distance } \\
(\mathrm{m})\end{array}$} & \multicolumn{2}{|c|}{$\begin{array}{c}\text { Ground-Level } \\
\text { Concentration }\left(\left[\mathrm{mg} / \mathrm{m}^{3}\right] \text { per }\right. \\
\mathrm{kg} \text { contaminant released })\end{array}$} & \multirow[b]{2}{*}{ Sigma Y $(\mathrm{cm})$} \\
\hline & 20 Minutes & 60 Minutes & \\
\hline 50 & 0 & 0 & 30 \\
\hline 100 & 2.54E-06 & $2.54 \mathrm{E}-06$ & 34.2407 \\
\hline 150 & $8.73 \mathrm{E}-05$ & $8.73 \mathrm{E}-05$ & 35.4431 \\
\hline 200 & $2.35 \mathrm{E}-04$ & $2.35 \mathrm{E}-04$ & 38.0795 \\
\hline 250 & $4.16 \mathrm{E}-04$ & $4.15 \mathrm{E}-04$ & 41.1502 \\
\hline 300 & $6.44 \mathrm{E}-04$ & $6.43 \mathrm{E}-04$ & 44.4944 \\
\hline 400 & $1.18 \mathrm{E}-03$ & $1.18 \mathrm{E}-03$ & 50.7454 \\
\hline 500 & $1.49 \mathrm{E}-03$ & $1.49 \mathrm{E}-03$ & 57.0603 \\
\hline 600 & $1.62 \mathrm{E}-03$ & $1.61 \mathrm{E}-03$ & 63.5176 \\
\hline 700 & $1.70 \mathrm{E}-03$ & $1.70 \mathrm{E}-03$ & 69.702 \\
\hline 800 & $1.65 \mathrm{E}-03$ & $1.65 \mathrm{E}-03$ & 75.8088 \\
\hline 900 & $1.64 \mathrm{E}-03$ & $1.63 \mathrm{E}-03$ & 82.0784 \\
\hline 1,000 & $1.70 \mathrm{E}-03$ & $1.69 \mathrm{E}-03$ & 88.042 \\
\hline 1,250 & $1.81 \mathrm{E}-03$ & $1.80 \mathrm{E}-03$ & 102.2467 \\
\hline 1,500 & $1.80 \mathrm{E}-03$ & $1.78 \mathrm{E}-03$ & 115.984 \\
\hline 1,750 & $1.66 \mathrm{E}-03$ & $1.64 \mathrm{E}-03$ & 134.219 \\
\hline 2,000 & $1.48 \mathrm{E}-03$ & $1.47 \mathrm{E}-03$ & 157.009 \\
\hline 2,500 & $1.17 \mathrm{E}-03$ & $1.15 \mathrm{E}-03$ & 206.17 \\
\hline 3,000 & $9.68 \mathrm{E}-04$ & $9.49 \mathrm{E}-04$ & 258.059 \\
\hline 3,500 & $8.28 \mathrm{E}-04$ & 8.09E-04 & 311.259 \\
\hline 4,000 & 7.05E-04 & $6.86 \mathrm{E}-04$ & 365.288 \\
\hline 4,500 & $6.02 \mathrm{E}-04$ & $5.83 \mathrm{E}-04$ & 421.361 \\
\hline 5,000 & 5.22E-04 & $5.03 \mathrm{E}-04$ & 478.148 \\
\hline 6,000 & 4.12E-04 & $3.94 \mathrm{E}-04$ & 596.512 \\
\hline 7,000 & $3.41 \mathrm{E}-04$ & $3.23 \mathrm{E}-04$ & 715.026 \\
\hline 8,000 & $2.84 \mathrm{E}-04$ & $2.66 \mathrm{E}-04$ & 836.439 \\
\hline 9,000 & $2.39 \mathrm{E}-04$ & $2.22 \mathrm{E}-04$ & 959.223 \\
\hline 10,000 & $2.03 \mathrm{E}-04$ & $1.86 \mathrm{E}-04$ & 1083.93 \\
\hline 12,500 & $1.44 \mathrm{E}-04$ & $1.29 \mathrm{E}-04$ & 1408.22 \\
\hline 15,000 & $1.10 \mathrm{E}-04$ & $9.68 \mathrm{E}-05$ & 1736.37 \\
\hline 17,500 & 8.72E-05 & $7.57 \mathrm{E}-05$ & 2067.91 \\
\hline 20,000 & $6.98 \mathrm{E}-05$ & $5.99 \mathrm{E}-05$ & 2401.68 \\
\hline
\end{tabular}

a Parameters: wind $=3.00000 ; \mathrm{u}^{*}=0.250000$;

$\mathrm{L}=60.0000 ; \mathrm{Zi}=140.000 ;$ time $=60$ minute fire. 
A-10 
$B-1$

APPENDIX B:

EMISSION FACTORS FOR BURNING VEGETATION 
B-2 


\section{APPENDIX B: \\ EMISSION FACTORS FOR BURNING VEGETATION}

Table B.1 lists chemical emission factors of components in smoke condensates from burning uncontaminated vegetation at APG (McKenzie et al. 1995). The values given are release amounts (grams) per dry mass (kilogram) of fuel burned ( $/ \mathrm{kg}$ ). McKenzie et al. (1995) obtained these data by examining the organic emissions from burning vegetation from a ponderosa pine forest in Montana. Because the fires occurring at Aberdeen Proving Ground occur in southeastern deciduous forests, the vegetation would differ from that found in the Montana forest. Therefore, on the basis of a recommendation from a scientist involved in the Montana study (Richards 1997), all of the emission factors were multiplied by five to be conservative and account for any differences in vegetation.

The emission factors were separated into the two categories to match the areas chosen for this study - forested area and field area. The emission factors from "wood" were used to estimate release from a forest fire, and the factors were then multiplied by the total estimated biomass available to burn in a forest fire at APG. The emission factors from "litter" were used to represent emissions from a field fire, and these factors were then multiplied by the estimated total biomass available to be burned in a field fire at APG. Estimation of biomass amounts is discussed in Section 6 and listed in Table 6.

Two of the chemicals released from burning biomass, 2-furaldehyde and vinyl acetate, were examined more closely in this study because they are suspected carcinogens. 
TABLE B.1 Emission Concentrations ( $\mathrm{g} / \mathrm{kg}$ ) of Constituents in Smoke Condensates of Various Fuels

\begin{tabular}{|c|c|c|}
\hline Chemical & $\begin{array}{l}\text { Forest Fire } \\
\text { Emissions }^{\mathrm{a}}\end{array}$ & $\begin{array}{l}\text { Grassy Area } \\
\text { Emissions }^{b}\end{array}$ \\
\hline 1-Hydroxy-2-propanone (acetol) & 2.00 & 0.3 \\
\hline 2-Cyclopenten-1-one & 0.19 & 0.07 \\
\hline 2-Furaldehyde & 0.81 & 0.8 \\
\hline 3-Oxybutanoic acid, methyl ester & 0.77 & 0.1 \\
\hline 2-Furanmethanol & 0.28 & 0.1 \\
\hline$\gamma$-Butyrolactone & 0.17 & 0.05 \\
\hline (5H)-Furanone & 0.22 & 0.07 \\
\hline 2-Acetylfuran & 0.054 & 0.02 \\
\hline 5-Methyl-2-furaldehyde & 0.15 & 0.2 \\
\hline Phenol & 0.11 & 0.07 \\
\hline o-Hydroxybenzaldehyde & 0.015 & $N^{c}$ \\
\hline 2-Methylpenol (o-cresol) & 0.042 & 0.02 \\
\hline 3 and/or 4 Methylphenol (m/p-cresol) & 0.044 & 0.04 \\
\hline 2-Methoxyphenol (guaiacol) & 0.18 & 0.1 \\
\hline Benzoic acid & 0.02 & ND \\
\hline 2-Methoxy-4-methylphenol (4-methylguaiacol) & 0.26 & 0.2 \\
\hline 2-Methoxy-4-(1-prop-2-enyl)phenol (eugonol) & 0.068 & ND \\
\hline 4-Hydroxy-3-methoxy-benzaldehyde (vanillin) & 0.076 & 0.2 \\
\hline Vinyl acetate & 3 & 0.5 \\
\hline Pyruvic aldehyde & 2.0 & ND \\
\hline Acetic acid & 4.4 & 0.85 \\
\hline Formic acid & 0.97 & 0.038 \\
\hline Propanoic acid & 0.25 & 0.11 \\
\hline Crotonic acid & 0.068 & ND \\
\hline Methanol & 4.3 & 0.69 \\
\hline Butyric acid & ND & 0.035 \\
\hline Hexamethylenetetraamine & ND & 0.28 \\
\hline Pyridine & ND & 0.2 \\
\hline Benzonitrile & ND & 0.050 \\
\hline
\end{tabular}

a The forest fire emissions are the release amounts from a smoldering forest fire, which produces higher release concentrations than a hotter fire of the type that would burn 25 acres in an hour (McKenzie 1995).

b The grassy area fire emissions represent the concentrations released from the self-sustained smoldering of burning litter (McKenzie 1995).

c $\mathrm{ND}=$ not detected. 


\section{REFERENCES FOR APPENDIX B}

McKenzie, et al., 1995, "Measurement and Modeling of Air Toxins from Smoldering Combustion of Biomass," Environmental Science and Technology 29(8):2047-2050.

Richards, G.M., 1997, personal communication from Richards (University of Illinois, ChampaignUrbana, Ill.) to A. Policastro (Argonne National Laboratory, Argonne, Ill.). 
B-6 
C-1

APPENDIX C:

FIGURES 
C-2 


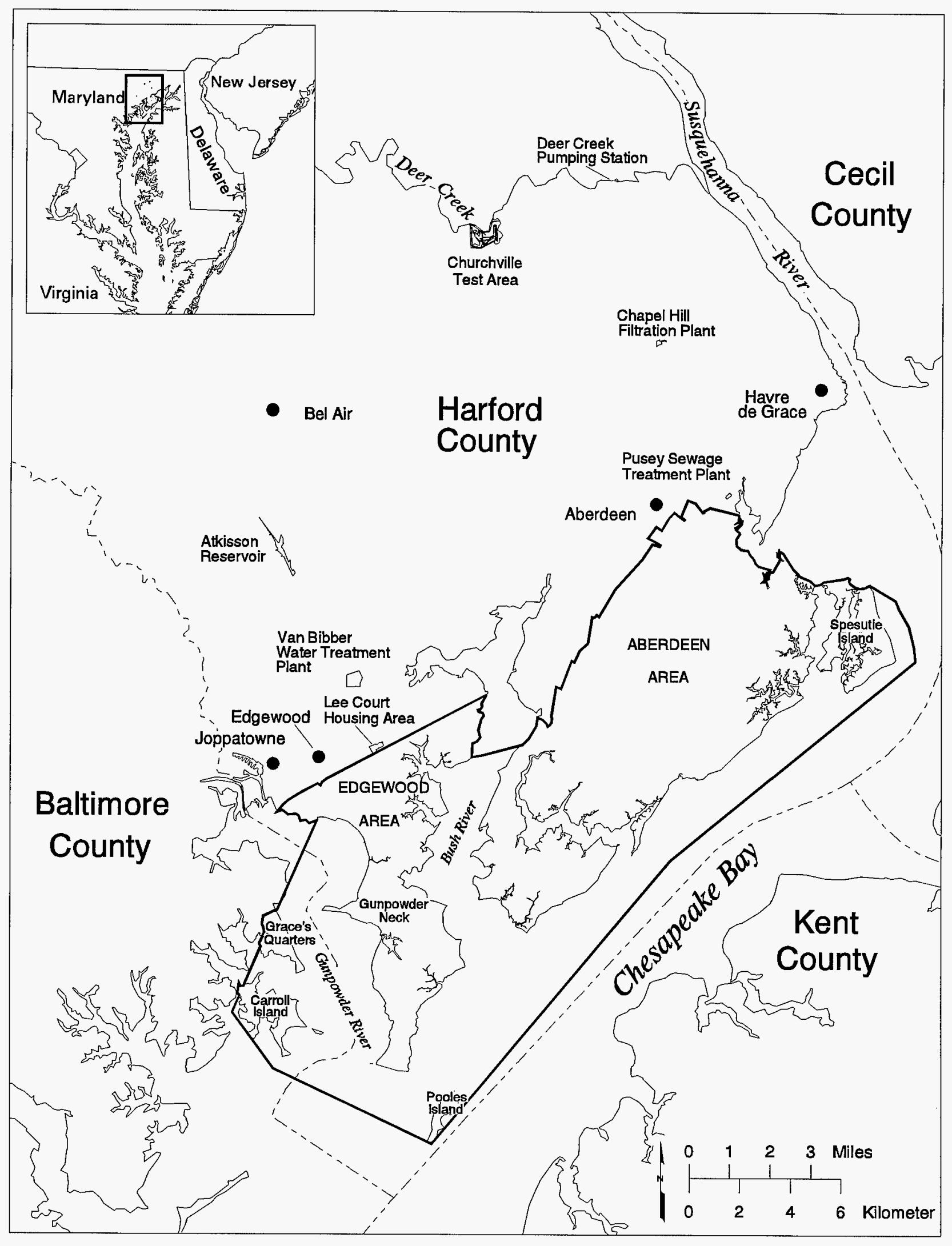

FIGURE 1 Map of Aberdeen Proving Ground and Surrounding Area 


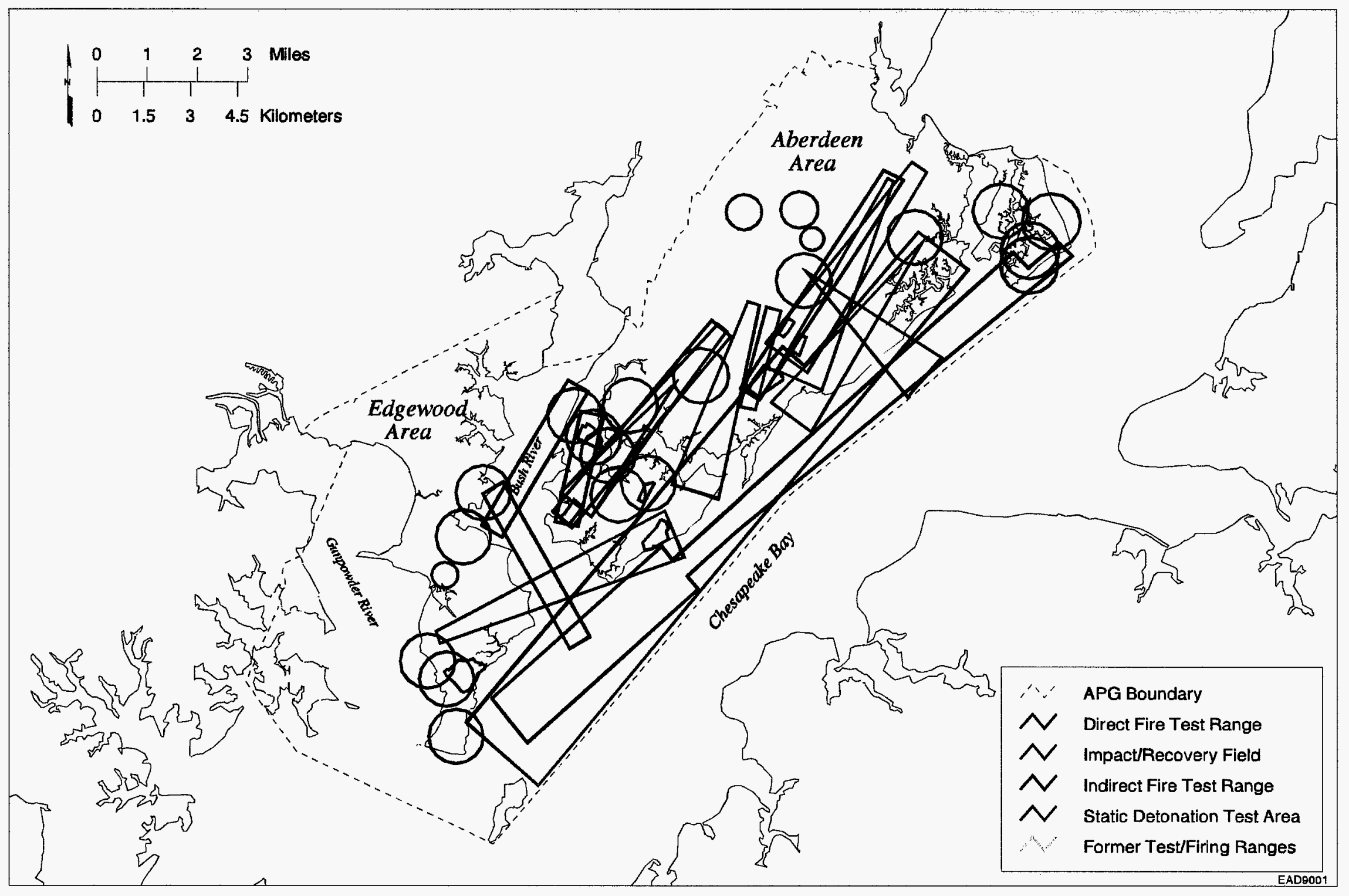

$i$

FIGURE 2 Locations of Firing Ranges at APG 


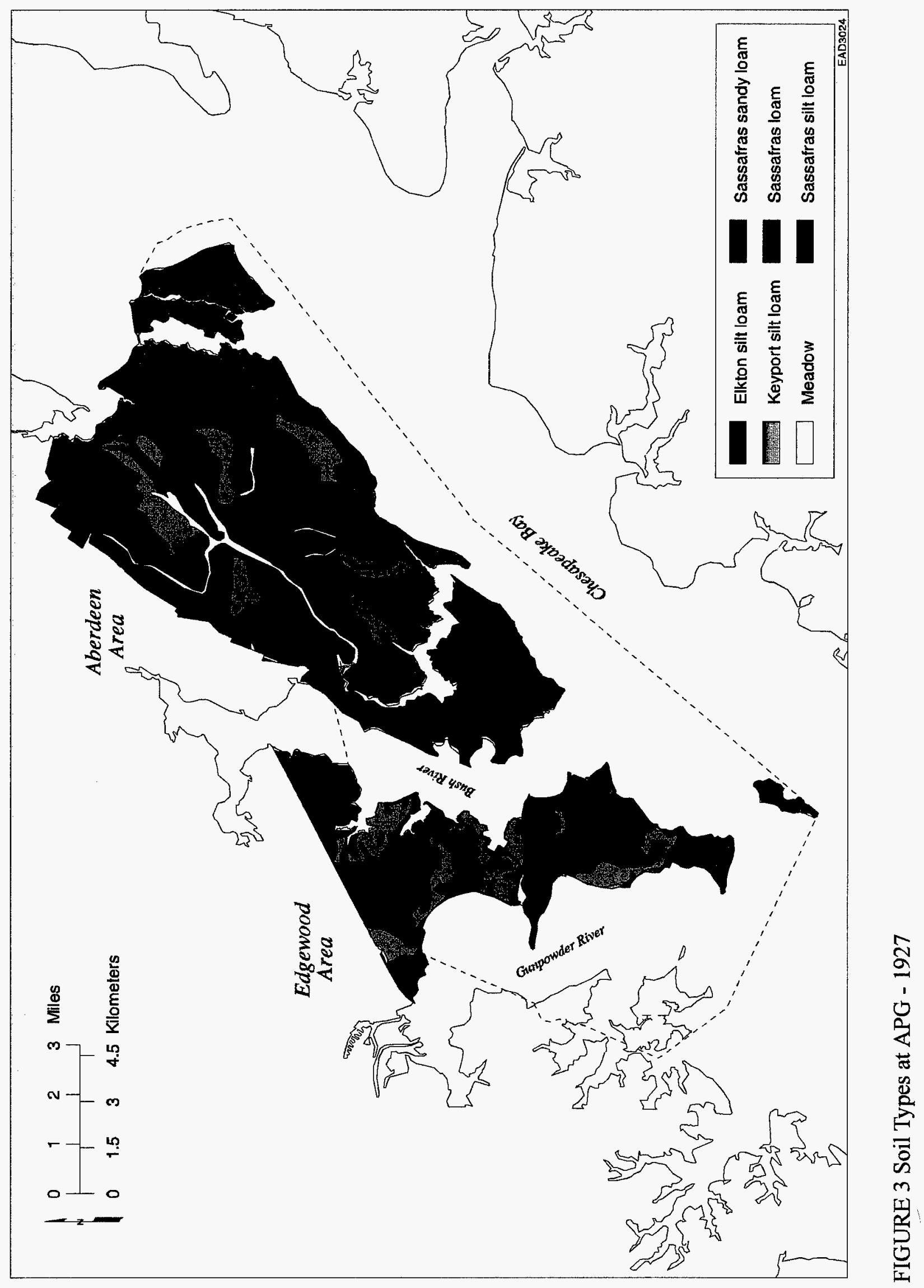




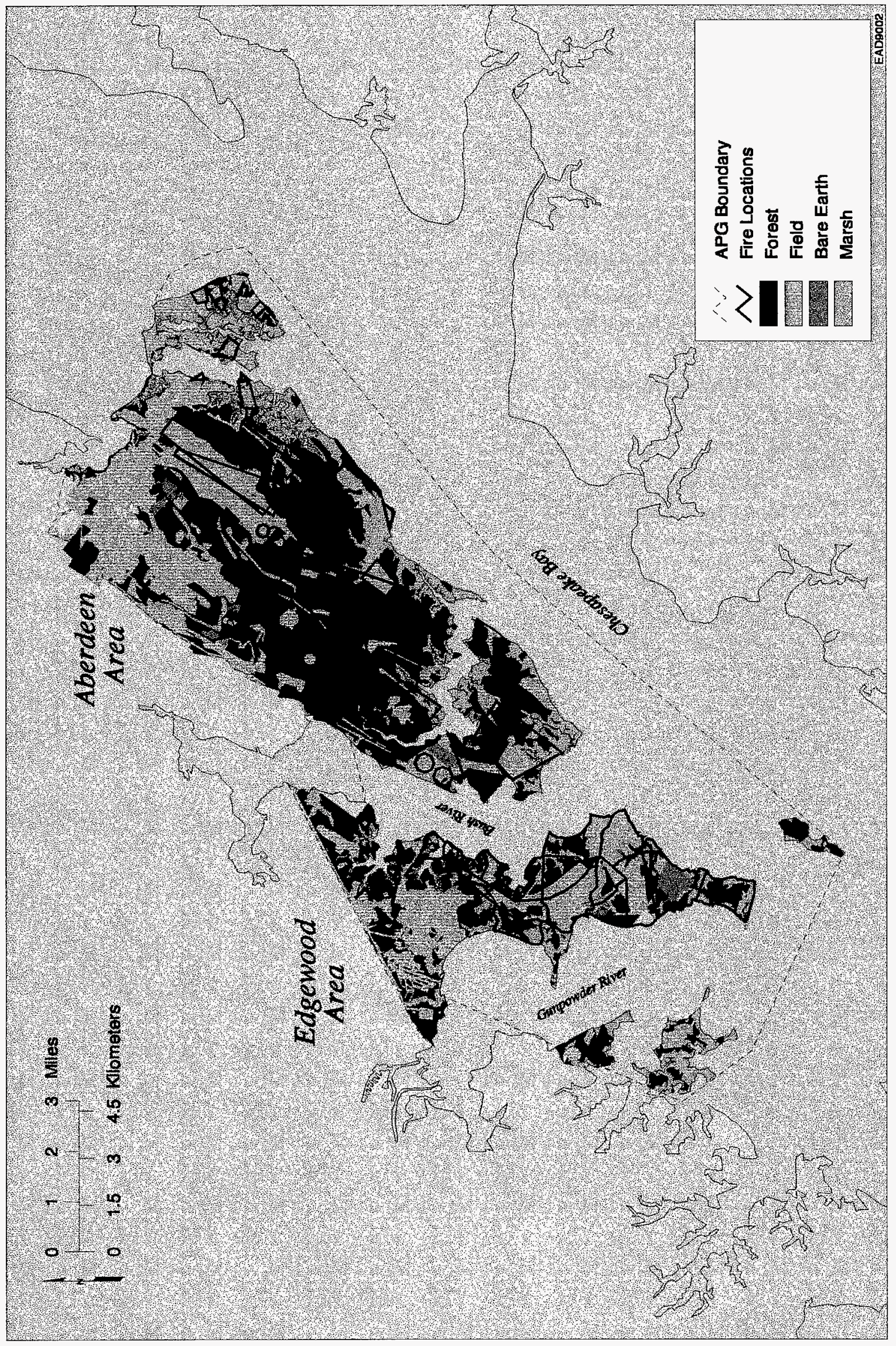

0
0
0
0
0
0
0
0
0
0
0
0
0
0
0
0
0
0
0
0
0
0
0
0
0 


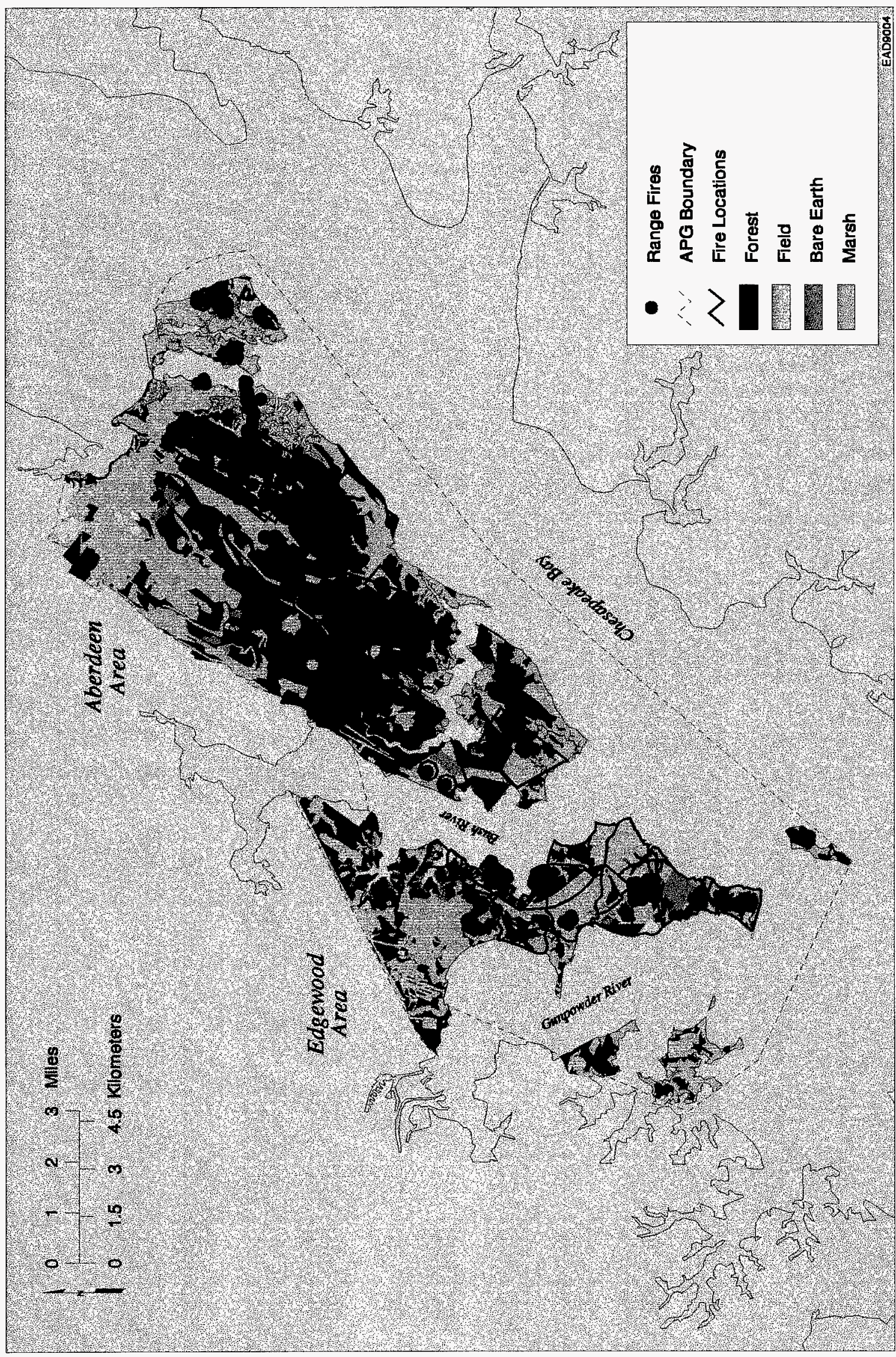

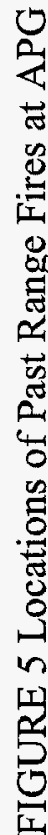




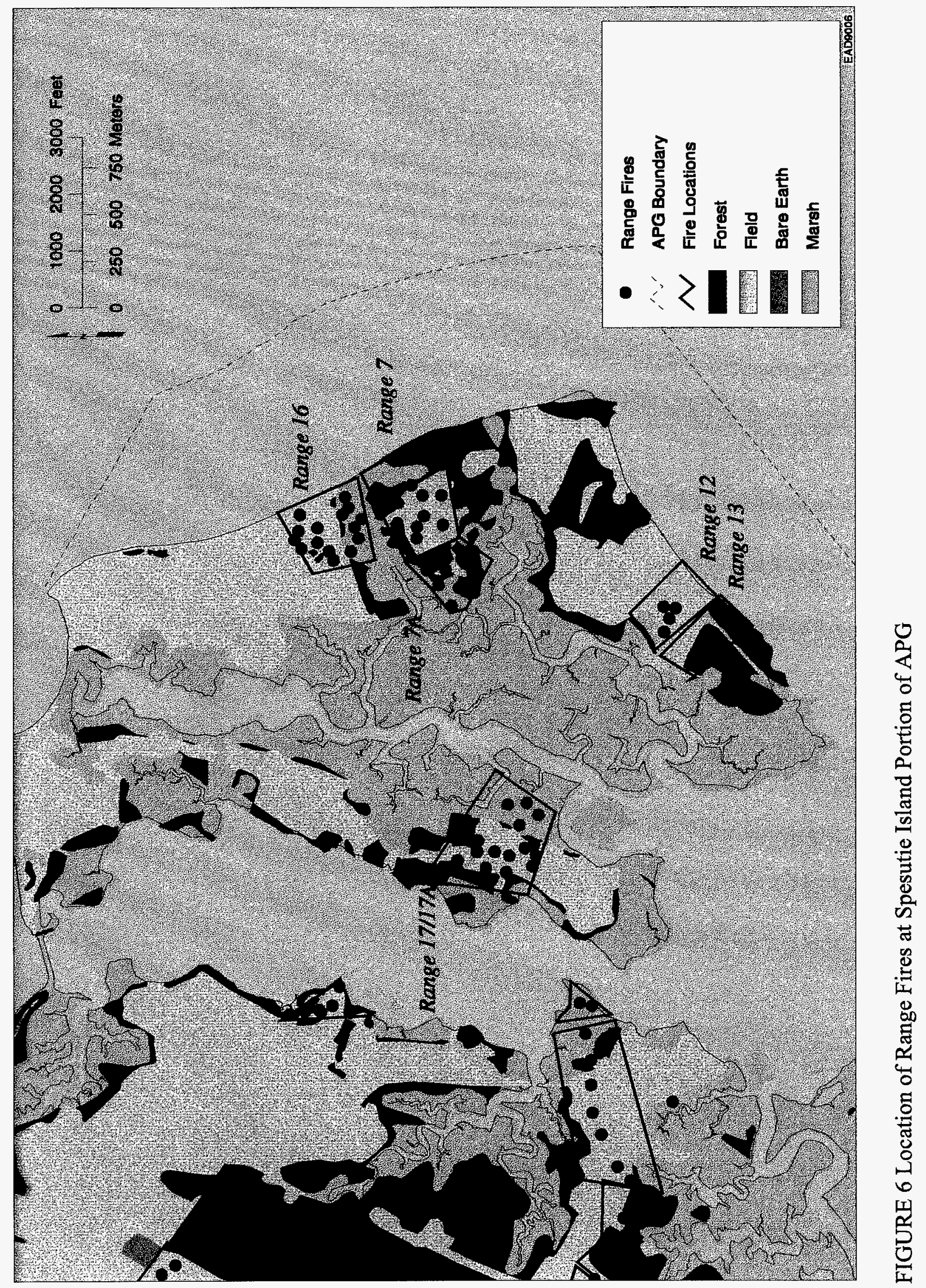




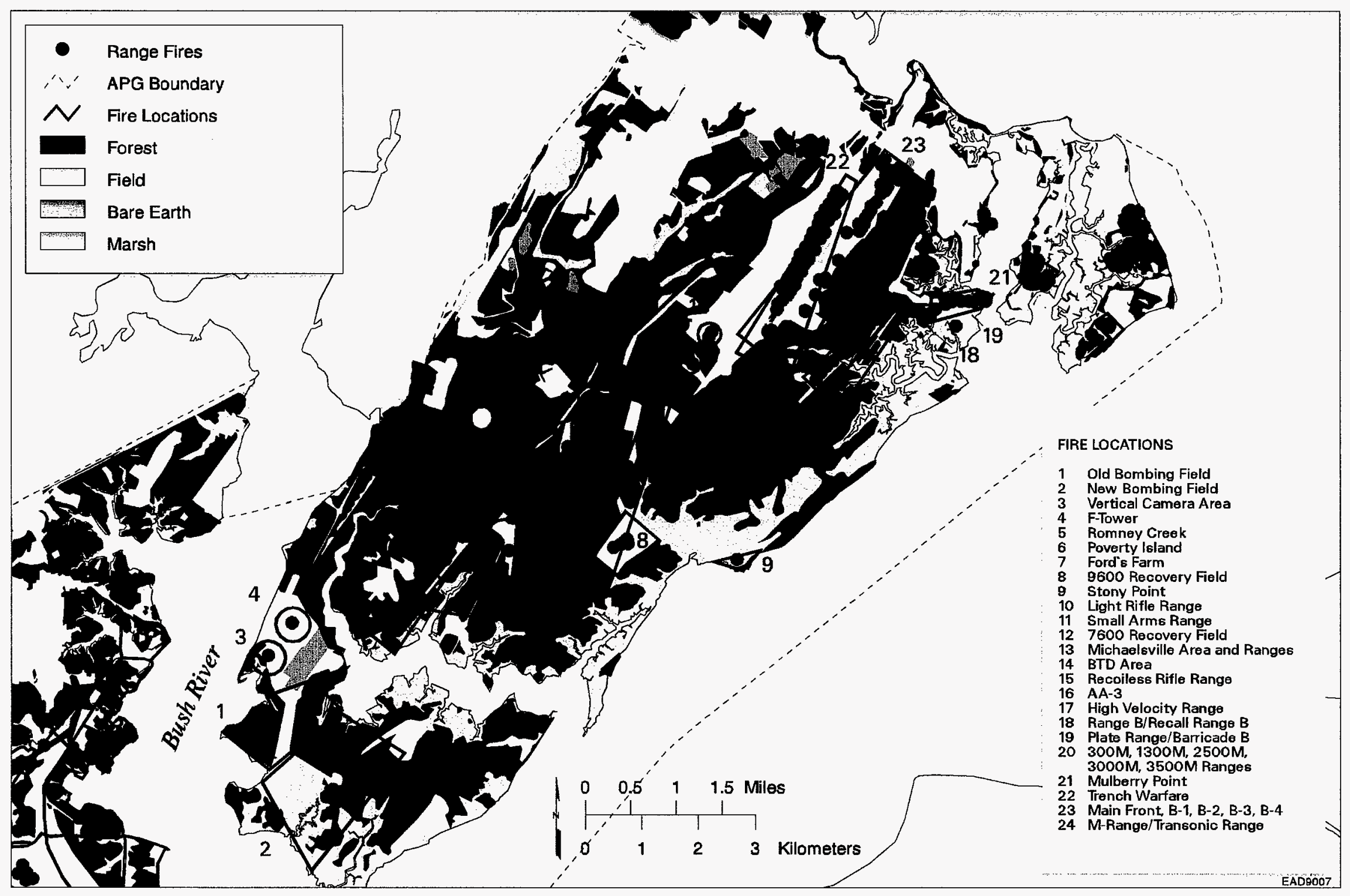

FIGURE 7 Locations of Range Fires at Aberdeen Area of APG 


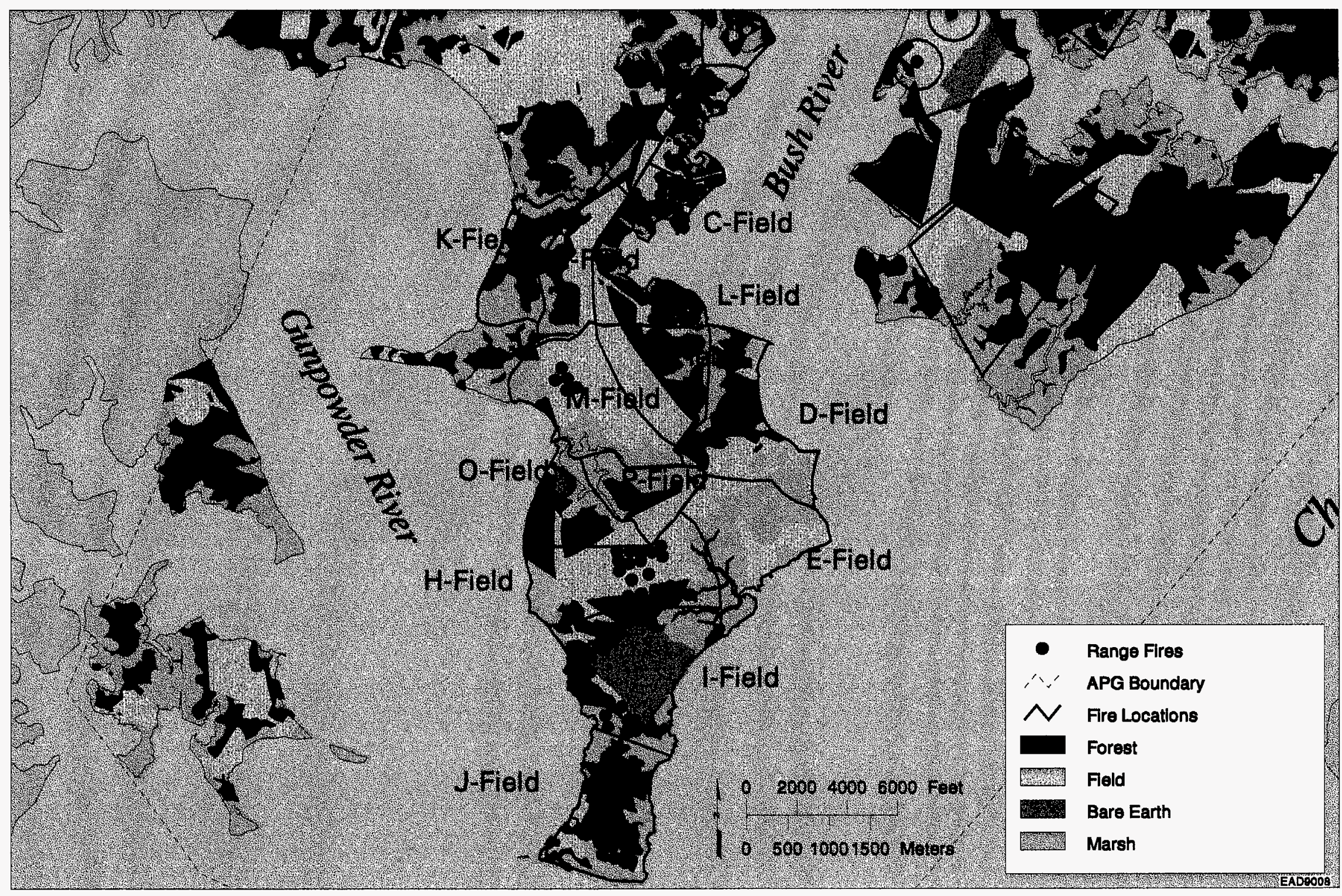

$\frac{2}{8}$

FIGURE 8 Location of Range Fires at Edgewood Area of APG 


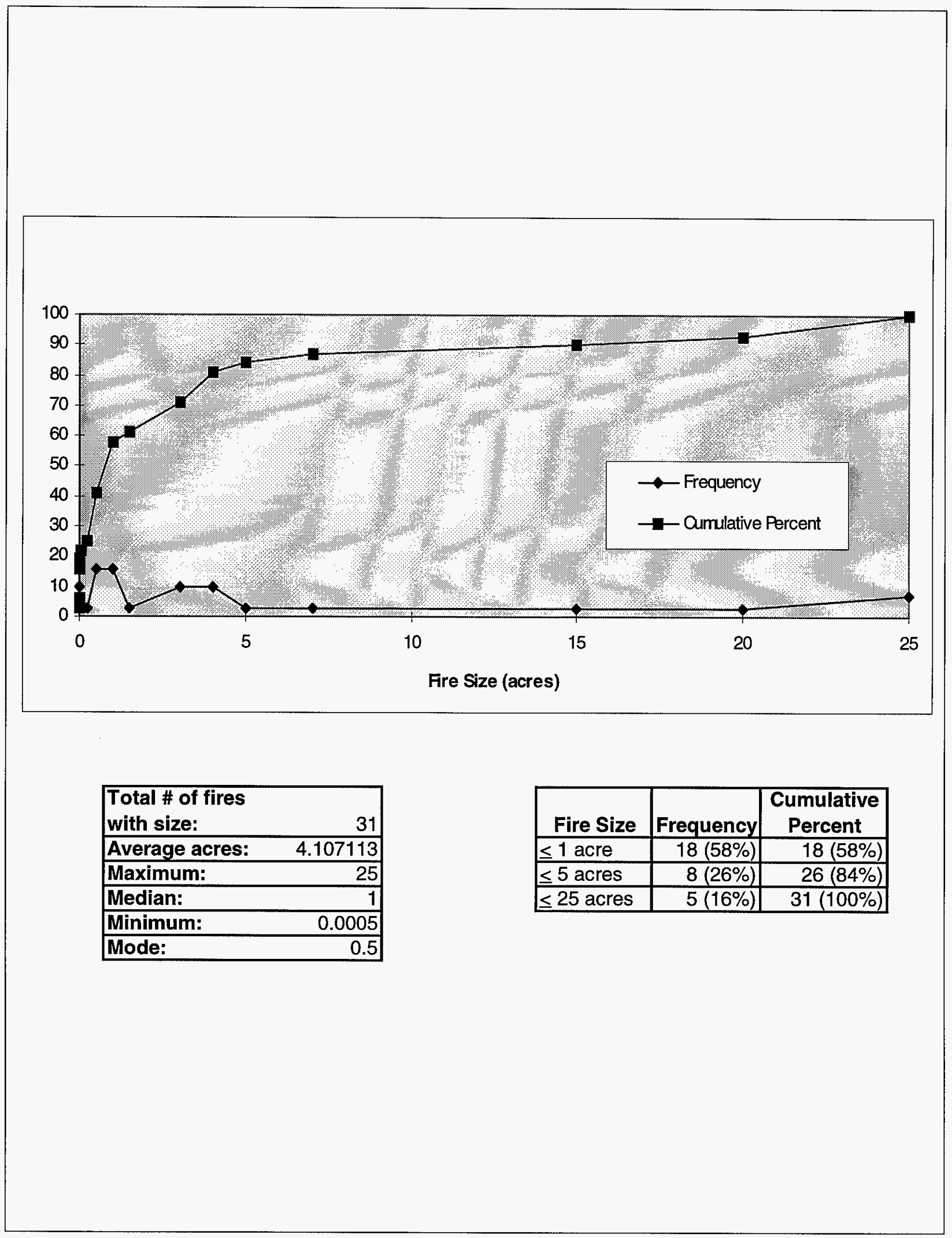

FIGURE 9 Size Distribution of Reported Range Fires at APG 


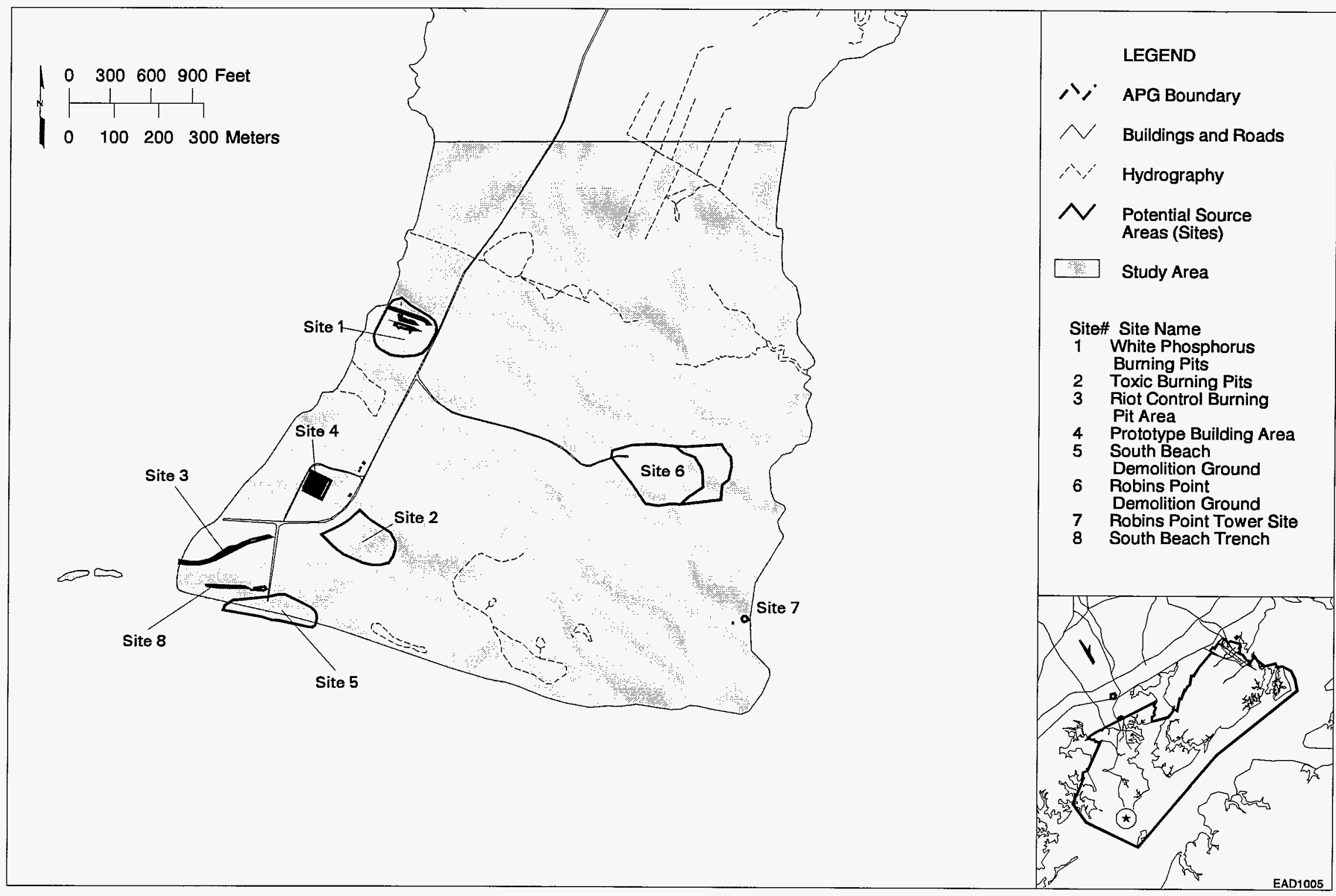

FIGURE 10 Locations of Potential Contamination Source Sites in the J-Field Study Area 


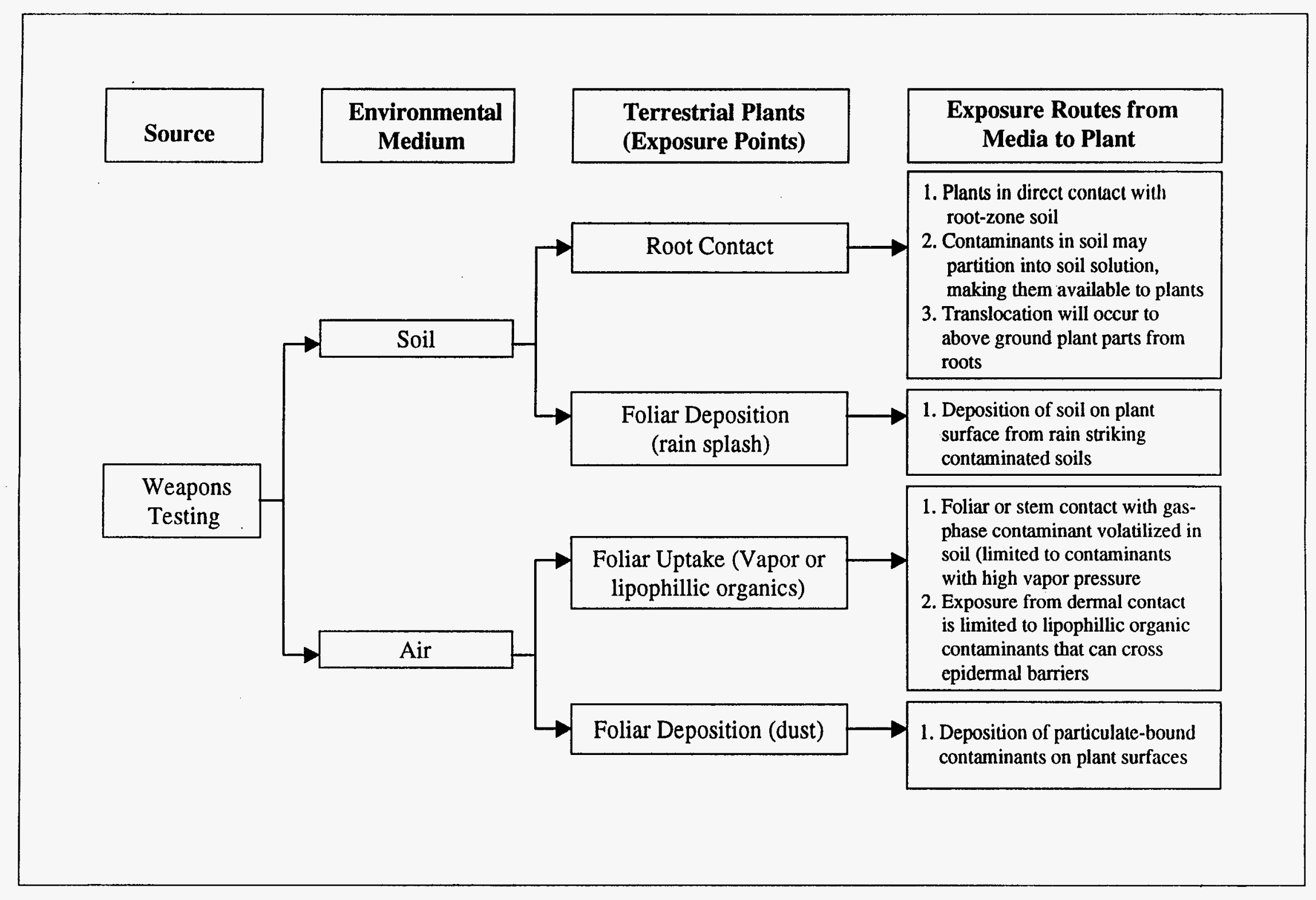

FIGURE 11 Pathways of Contaminants from Testing Projects 
A stability

$2 \mathrm{~m} / \mathrm{s}$
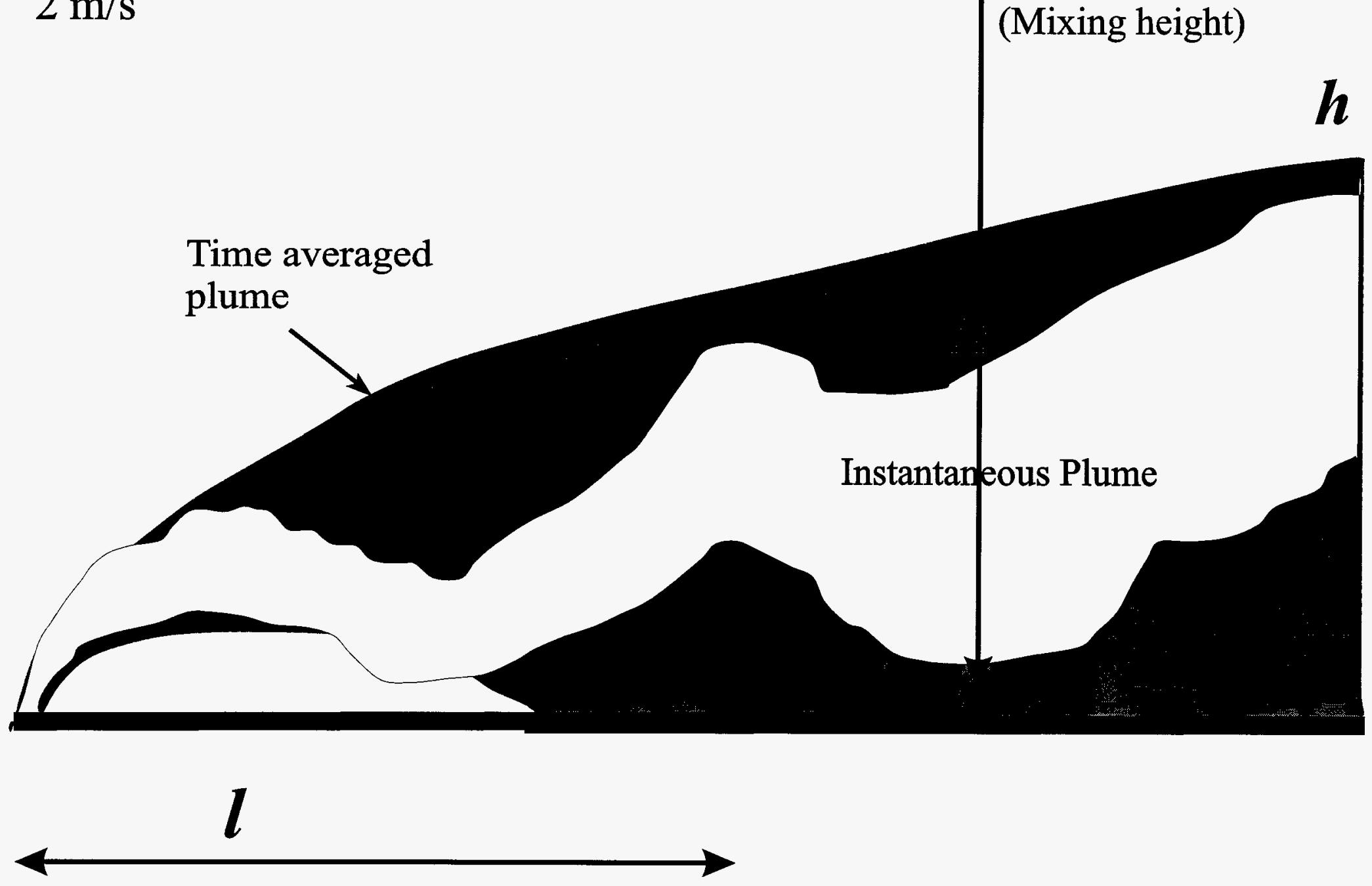

FIGURE 12 Cross-Section of Smoke Plume for Stability Class A Conditions 


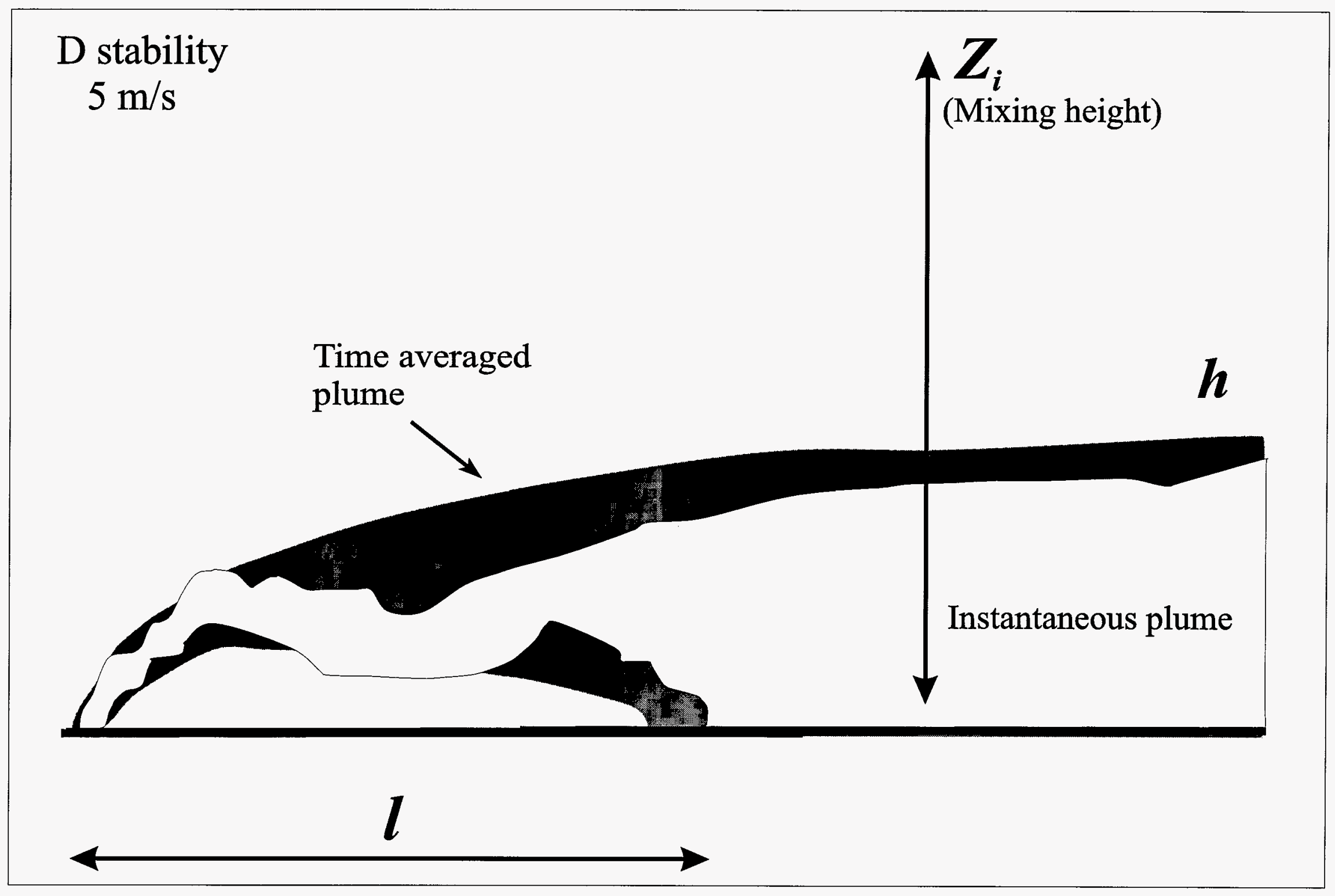

FIGURE 13 Cross Section of Smoke Plume for Stability Class D Conditions 


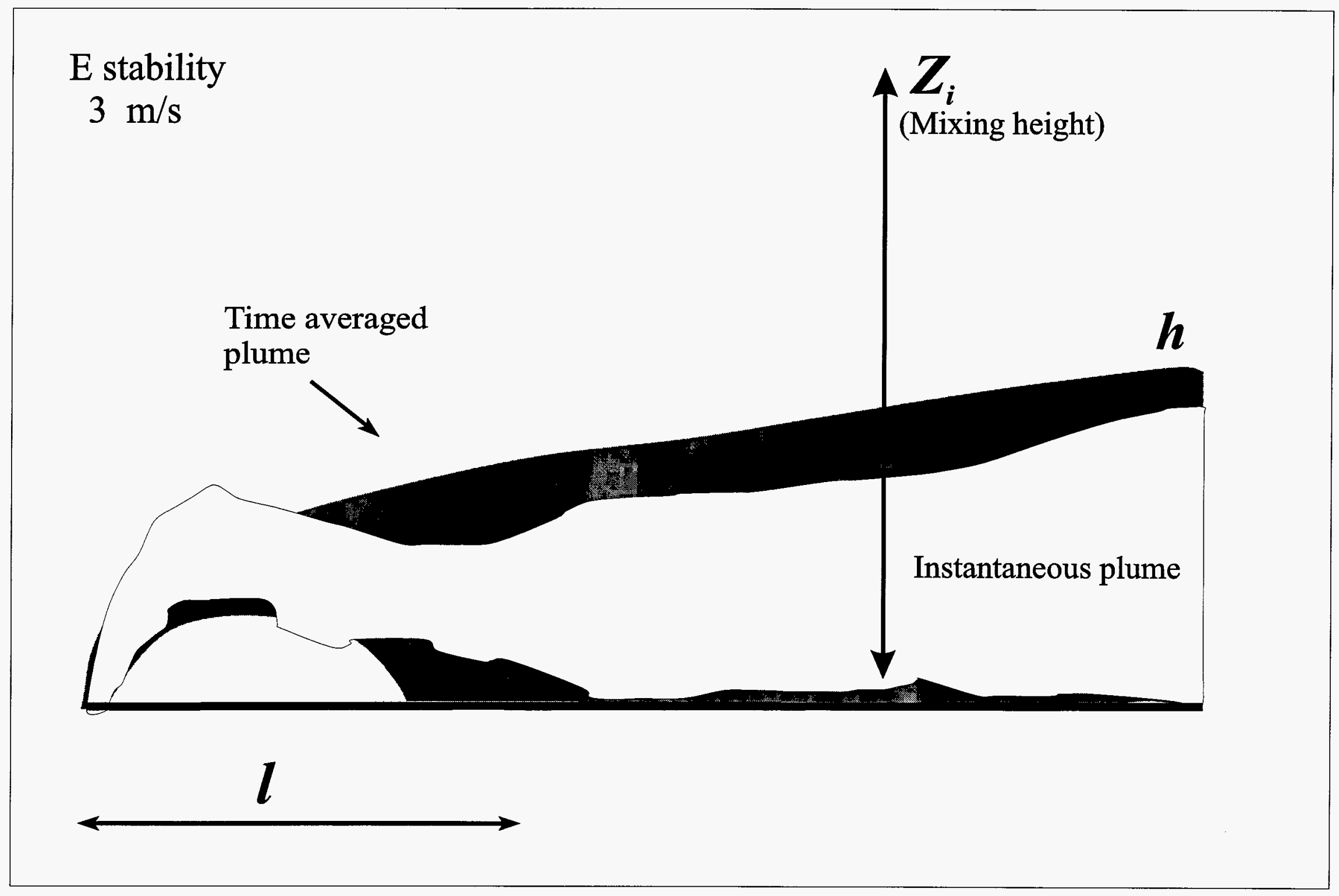




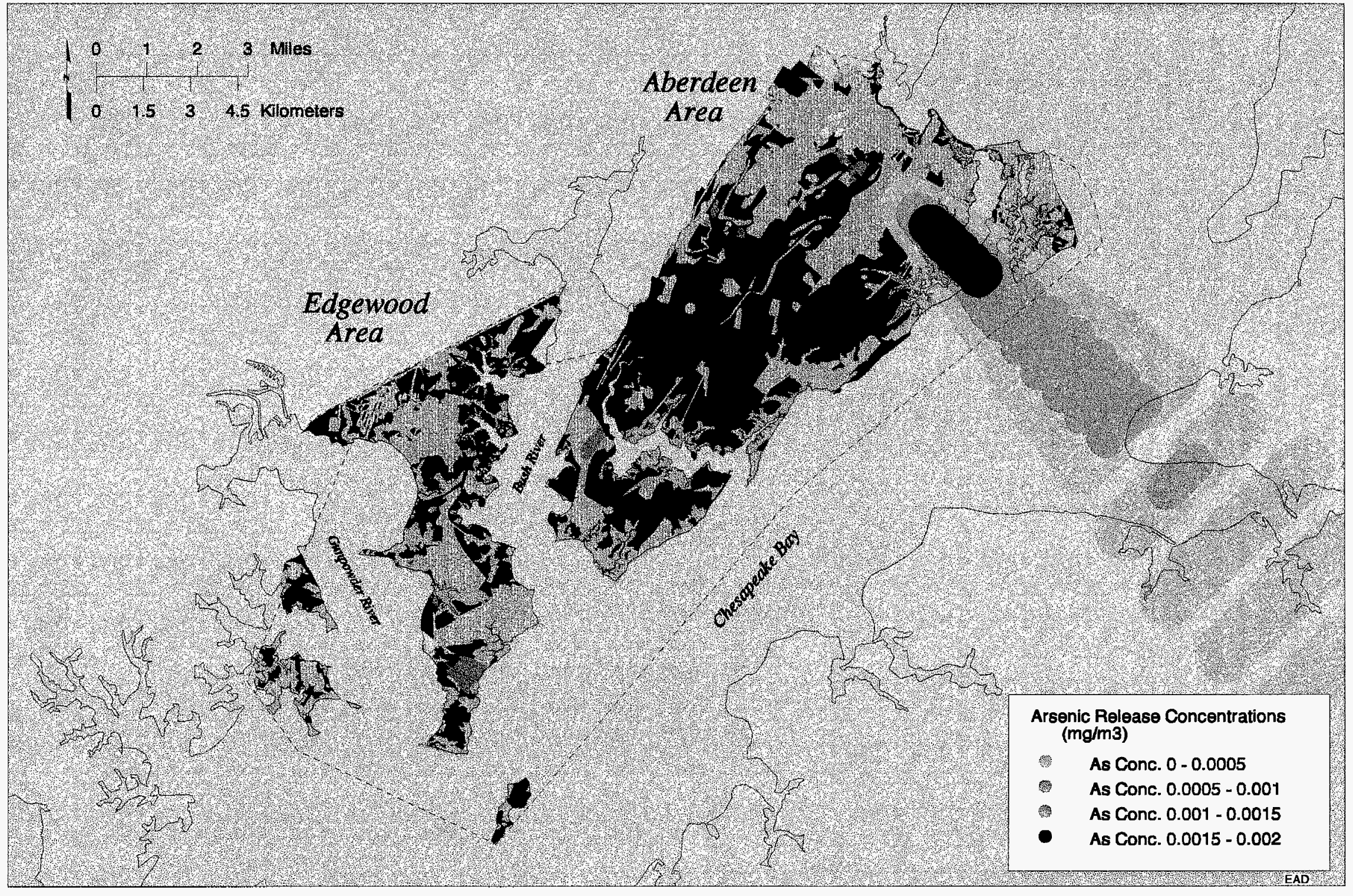

FIGURE 15 Map Showing Distribution of Ground-Level Predicted Arsenic Concentrations 


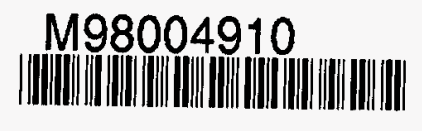

Report Number (14) UL/ $/ E$ AD/TM- T

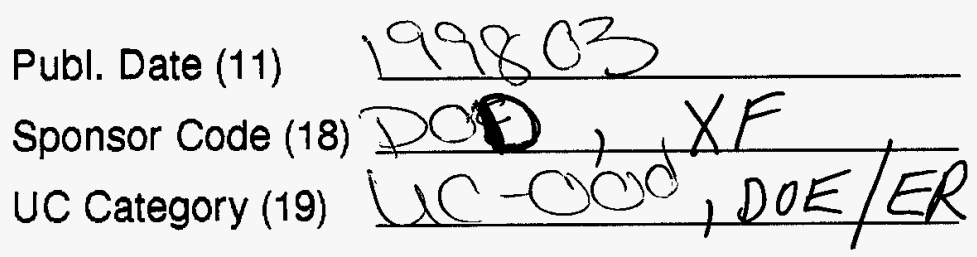

